UCRT, -15506

DE33001200

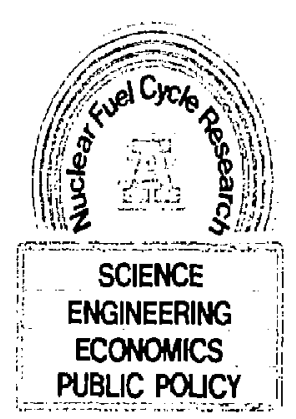

UNIVERSTY OOFPRONA

- Nuclear-Fuel-Cycle Research Program:

AVAILABILITY OF GEOTOXIC MATERIAL

MASTER

SEPTEMBER 1982

B. G. Wachter

P. L. Kresan

Subcontract 1879901

Lawrence Livermore National Laboratory

To Engineering Experiment Station

The University of Arizona 


\title{
AVAILABILITY OF GEOTOXIC MATERIAL
}

\section{Prepared for}

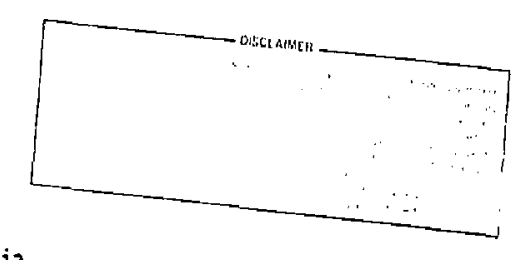

University of California

Lawrence Livermore National Laboratory

Subcontract 1879901

\author{
By \\ B. G. Wachter \\ P. L. Kresan \\ University of Arizona \\ Nuclear Fuel Cycle Research Program
}

Edited by

F. J. Ciminesi

California State University, Hayward

HOTICE Department of Geological Sciences

PORTIONS OF TiHS REPCAT ARE ILLEGIOLE. It

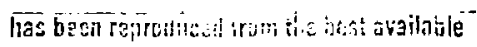

copy to permit tha brcadest possitste avail.

ability.

September 1982 
This report represents an andiog approach to the characterization of the environmental behavior of geotoxic waste materials as drawn from literature on the natural nodels:

a. Oklo natural fission reactors and uranium ore deposits relative to radioactive wastes, and

b. hydrothermal metal ore deposits relative to stable toxic wastes. The geochemical literature proved to be the most significant source of information and direction of research. The geologic and hyorologic literature was found to be relatively less useful in this study. The natural analog data were examined in terms of mobility and imnobility of selected radioactive or staole waste elements and are presented in matrix relationship with their prime geocinemical variables.

A numerical system of ranking tnose relationships for purposes of hazard-indexing is proposed. This numerical system is based on the "availaoility" term developed by Smith et al. (1980), specifically in terms of their m-factors ac discussed herein. Table summaries (matrices), text elucidation and additional technical excerpts in the appendix provide a tri-level look at the interaction between selected elements and their geochenical variables.

Geochenical parameters (especially oxidation/reduction potential) are apparently more potent mobilizers/immobilizers than geological or hydrological conditions in many, if not most, geclogic environments for most radioactive waste elements. Heavy metal wastes, by analogy to hydrothermal ore systems and geothermal systems, are less clear in their behavior but similar geochemical patterns do apply. 
Depth relationships between geochemical variables and waste element behavior show some surprises. It is significantly indicated that for waste isolation, deeper is not necessarily better geocnemically. Relatively shallow isolation in host rocks such as shale could offer maximum immobility. This paper provides a geochemical outline for examining analog models as well as a departure point for improved quantification of geological and geocnemical indexing of toxic waste hazards. 
LIST OF TABLES . . . . . . . . . . . . . . . . viii

LIST OF FIGURES . . . . . . . . . . . $x$

EXECUTIVE SUMMARY . . . . . . . . . . . . xiii

ACKNOWLEDGEMENTS . . . . . . . . . . . . . . xvi

I. PURPOSE AND REPORT ORGANIZATION . . . . . . . . . I

II. APPROACH . . . . . . . . . . . . . 4

A. Analog Application . . . . . . . . . . 4 4

B. m-factor . . . . . . . . . . . . 5

C. Format . . . . . . . . . . 6

III. NATURAL MOdeLS FOR RADIOACTIVE haSte behaviOR . . . . , 20

A. Oklo Natural Fission Reactor (General) . . . . . 20

B. Uranium Ore Deposits - Introduction . . . . . . 23

1. Uranium Ore Deposit Types . . . . . . . . . . 24

2. Summary of Uranium Deposit Chemistry . . . . . . 31

3. Uranium Deposition and Mobility; Reducing Environment . 32

4. Uranium Deposition and Mobility; Dxidizing Environment . 33

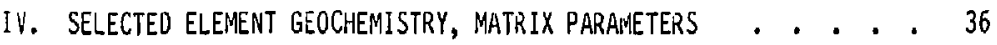

A. Actinide Geochemistry . . . . . . . . . 36

B. Comparison of Act inide and Lanthanide Chemistry . . . 48

C. Lantnanide Geochemistry . . . . . . . . 49

D. Alkali Metals (Rb and Cs) Geochemistry . . . . . 50

E. Alkal ine Earths $(\mathrm{Ca}, \mathrm{Sr}, \mathrm{Ba}, \mathrm{Ra})$ Geochemistry . . . . . 50

F. Iodine . . . . . . . . . . . 52

G. Metals . . . . . . . . . . . . 52

H. Technetium .............. 53

v. Geochemical parameters USED in Matrix . . . . . . . 54

A. Effects of En on Actinide Geochemistry . . . . . . 54

B. Effects of pH on Actinide Geochenistry . . . . . . . 55

C. Effects of Mineralogy on Actinide Geochemistry . . . . 55

D. Effects of the Presence of Anions of Actinide Geochemistry . 56

E. Effects of Temperature on Act inide Geochemistry . . . 57 
VI. SORPTION . . . . . . . . . . . . . . . . . .

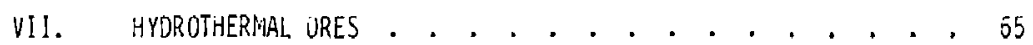

A. Mobility . . . . . . . . . . . . . 05

B. Deposition . . . . . . . . . . . . . . . . . 66

C. Supergene Processes (Remodilization of metals in trie

weatnering/oxidizirig environiulul) . . . . . . . . . 07

D. Hydrotnerinal Alteration (Bulk-rock mineral cnanges aue to hydrutnerilal activicy). . . . . . . . 67

VIII. OEPTH . . . . . . . . . . . . . . . 71

1. Porosicy/Perneavility/Deptı Kelationsnips . . . . . . 71

B. Deptn-related Salinity . . . . . . . . . 75

C. Depth-related $\mathrm{pH}$. . . . . . . . . . . . . 78

0. Depth-related En . . . . . . . . . . . . 78

E. Otner Deptn Functions . . . . . . . . . . . . . 80

F. Sumary of Deptin Implications to Haste Isolation . . . . 81

IX. CUNCLUSIUNS ANO SUggestions FOR FURTHER hORK . . . . . . 83

X. REFERENCES . . . . . . . . . . . . . 101

A. Raúloactive Waste Benavior . . . . . . . . . 101

B. Hydrutherillal Ores . . . . . . . . . . . . 112

XI. APPENDICES . . . . . . . . . . . . 115

A. Additional viscussion, Oklo . . . . . . . . . . A-l

B. Adaitional Discussior, Uranium Ueposition . . . , . , B-l

1. Vein-Type Ueposits . . . . . . . . . . . B-1

2. Redox Reactions Involving Caroon Compoundus . . . . . B-s

3. Redux Reactions Involving Sulfate/Sulfide . . . . . B-4

4. Clay Reactions . . . . . . . . . . . . . 6-5

5. Precipitating Ligands . . . . . . . . . . . $B-6$

C. Additional oiscussion of Uraniun lrobility . . . . . . . C C

o. Actinide Geocnemistry . . . . . . . . . . [ $0-1$

1. Uranium . . . . . . . . . . . . . . . . 0-1

2. Thorium . . . . . . . . . . . . . . D-2

3. Protactinium . . . . . . . . . . . D-2

4. Neptunium, plutoniuni, americium . . . . . . . 0-3

E. Effects of Eil on Actiniue Geocnenistry . . . . . . . . E-1

F. Effects of $\mathrm{pH}$ on Actiniae Geocnemistry . . . . . . . F-l

G. Effects of Mineralogy un Actiniue Geocnemistry . . . . . G-1 


\section{CONTENTS (continued)}

H. Effects of Anions on Actinide Geochemistry. . . . . . . H-l

1. Carbonate . . . . . . . . . . . . H-l

2. Phosphate . . . . . . . . . . . . H-3

3. Halogens . . . . . . . . . . . H-4

4. Sulfate/Sulfioe. . . . . . . . . . . H-5

5. Silica. . . . . . . . . . . . . H-6

6. Hydroxide . . . . . . . . . . . . H-6

I. Sorption Effects on Uranium . . . . . . . . . I-I

J. Sorption Effects on Selected Elements-Actinioes and Lallthanioes . . . . . . . . . . . . . . J-l

K. En, pH and Mineralogical Effects on Actinide Sorption . . K-1

L. Conditions fur Hydrotnernal Ore Formation . . . . . . L-I l. $\mathrm{pH}$. . . . . . . . . . . . . . . . L-1

2. Eh . . . . . . . . . . . . . . L-2

3. Pressurt . . . . . . . . . . . . . . . . L-2

4. Tellperature :. . . . . . . . . . . . . . L-3

5. Supercritical Solutions . . . . . . . . . . L-4

b. Composition of Solutions . . . . . . . . . . . L-5

7. Complexing in ore Solutions . . . . . . . . L-6

8. Gecthernal Systens . . . . . . . . . . . . . L-6

il. Complexes . . . . . . . . . . . . . . . M-1

1. Gerler d . . . . . . . . . . . . . M-1

2. Metal Complexes............. . . . M-3 
1. Components of Radioactive Wastes; Elements Selected for This Study . . . . . . . . . . . . . 9

2. Significant Nuciides in Radioactive Waste Management . . . . 10

3. Initial Radionuclide Concentration of Input Solid Wastes................ . . . 11

4. Immobilization/Mobilization; Geochemical Parameters Used as Matrix Headings . . . . . . . . . . . . . 12

5. Matrix Sumnary Format . . . . . . . . . . . . 13

6. Mobilization of Selected Nuclides in Geochemical Environments. . . . . . . . . . . 14

7. Immobilization of Selected Nuclides in Geochemical Environments . . . . . . . . . . . . . 15

8. m-Factors . . . . . . . . . . . 16

9. Observed Solubility Limits . . . . . . . . . . 48

10. Measured Sorptions for $\mathrm{SeO}_{4}=\mathrm{TcO}_{4}^{-}$and $\mathrm{I}^{-}$. . . . . . . 63

11. Compositions of Some Modern and Ancient Hydrothermal Solutions . . . . . . . . . . . . . 69

12. Representative Total (analytical) Concentrations in Hydrothermal Solutions . . . . . . . . . . .70

13. Estimated Compositions (weight per cent) of Three Samples of Sulfide-Rich Scale From Pipes Discharging Salton Sea Brines . . . . . . . . . . . . . . 88

14. Quantitative X-ray Fluorescence Analyses (weight por cent) and Mineralogical Assemblages of Sulfide-Rich Scale. . . . 89

15. Concentrations of Minor Elements in Waters From Geotherma] Wells and Springs . . . . . . . . . . . . 90

16. Examples of Geothermal Areas Explored by Drilling . , , . . 91

17. Estimated Composition of Dissolved Matter (in ppm) of Brines Produced from Two Bores in the Salton Sea . . . . . 92 


\section{LIST OF TABLES (Continued)}

18. Chemical Composition of Lurgi Ash and Slurry Supernatent Solutions of the Asn From Illinois No. 6 . . . . . . . 95

19. Discharge Severities for Constituents in Coal Utilization Solid Wastes . . . . . . . . . . . . . 97

20. Elements with Concentrations Exceeding Recommended Water Quality Levels . . . . . . . . . . . . . . 98

21. Highest Concentration of Copper and Samples Exceeding the U.S. Public Health Recommended Limit of the $1.0 \mathrm{ppm}$ for the Counties of Arizona

22. Highest Concentrations of Zinc and Samples Exceeoing the U.S. Public Health Recommended Limit of $5.0 \mathrm{ppm}$ for the Counties of Arizona . . . . . . . . . . . . . 99

23. Highest Concentration of Lead and Samples Exceeding the U.S. Public Health Service Mandatory Limit . . . . . . . 100

24. Highest Concentration of Cadmium and Samples Exceeding the U.S. Public Health Service Mandatory Limit . . . . . . 100 
1. Eh-pH diagram for part of the system U-S-Si-O-H-Fe . . . . . 25

2. Framework of Eh-pH diagrams . . . . . . . . . . 26

3. Eh-pH diagram for uranium and vanadium compounds at $25^{\circ} \mathrm{C}$ and $1 \mathrm{~atm}$ total pressure . . . . . . . . 27

4. En-pH diagram showing stability fields of common iron minerals $\ldots . . .28$

5. Fence diagram showing Eh-pH fields in which chemical end-members of noriclastic sediments are formed under normal sed-water conditions... . . . . . . . 29

6. Uranium Minerals . . . . . . . . . . . . 30

7. The effect of uranous-fluoride complexing on the solubility of uraninite $\mathrm{UO}_{2}(\mathrm{C})$, versus $\mathrm{pH}$ at $25^{\circ} \mathrm{C}$. . . . . . 37

8. Distribution of uranous complexes versus $\mathrm{pH}$ for some typical ligand concentration in ground water at $25^{\circ} \mathrm{C} . . .38$

9. Distribution of urinyl complexes versus $\mathrm{pH}$ for some typical ligand concentrations in ground waters of the wind River Formation at $25^{\circ} \mathrm{C}$

10. En-pH diagram in the $\mathrm{U}-\mathrm{O}_{2}-\mathrm{CO}_{2}-\mathrm{H}_{2} \mathrm{O}$ system at $25^{\circ} \mathrm{C}$ far $\mathrm{PCO}_{\mathrm{CO}}=$ $10^{-2} \mathrm{~atm}$. .............. 40

11. The solubility of uraninite, $\mathrm{UD}_{2}(\mathrm{c})$ at $\mathrm{pH}=8$ and $25^{\circ} \mathrm{C}$ as a function of $E h$ and $P_{i 02}$

12. The solubility of uraninite, $\mathrm{UO}_{2}(\mathrm{C})$, at $\mathrm{pH}=5$ and $25^{\circ} \mathrm{C}$ as a function of Eh for $\mathrm{P}_{\mathrm{CO} 2}=10^{2.0} \mathrm{~atm}$. . . . . 4]

13. Solubility of carnotite at $25^{\circ} \mathrm{C}$ as a function of $\mathrm{pH}$. . . . 42

14. Solubility of tyuyamunite at $25^{\circ} \mathrm{C}$ as a function of $\mathrm{pH} . . .43$

15. Solubility of autunite at $25^{\circ} \mathrm{C}$ as a function of $\mathrm{pH}$. . . . . 44

16. Solubility of potassium autunite at $25^{\circ} \mathrm{C}$ as a function of $\mathrm{pH} . .44$ 
17. Adsorption of uranyl onto $X$-ray amorphous ferric oxyhydroxide as a function of $\mathrm{pH}$. . . . . . . . 62

18. Approximate pressure-temperature fields of the principal metamorphic facies

19. Range in porosity of shales (ruled area) and sands (stippled area) as a function of depth of burial . . . . 74

20. Variation in major element concentration of waters in the Illinois dasin as a function of dissolved chloride content

21. Maximum observed salinities at various depths in the Illinois, Michigan, and Alberta basins . . . . . . . . 77

22. Change of the ionization constant of water with temperature . . 79

23. Equilibrium curves for the reaction $\mathrm{CaCO}_{3}+\mathrm{SiO}_{2},+, \cdot, 82$

24. Temperature-salinity relations in ore-forming fluids from Mississippi Valiey type districts 
(BLANK PAGE)

-xii- 


\section{EXECUTIVE SUMMARY}

Geotoxicity study evaluates the behavior of toxic material emplaced in the eartn's crust by either man or nature. It includes assessment of natural and man-made radioactive elements as well as certain stable metallic elements. The availability of geotoxic material is a major consideration in the Geotoxicity Hazard Index (GHI) which was developed by Smith et al. (1980). In their formulation, availability is dependent on a number of factors including the physical and chemical characteristics of the buried toxic material and its behavior in the geochemical environment. In the Geotoxicity Hazard Index, availability is characterized using the ratio of human intake to natural crustal abundance of the analog of the material under consideration. Since this value is indicative of the average availability of the analog material under normal conditions, it must be adjusted to accomiodate the particular circumstances, natural or engineered, of the disposal situation under study. This is accomplished through the use of a modification factor, or m-factor, that defines the combination of parameters causing deviation of availability from the average value.

The purpose of this report is essentially three-fold. First, it describes an analog approach to the assessment of hazardous waste disposal. The anaiog approach attempts to provide real-world instances of hazardous materials interacting witn the environment. Observations of these interactions are to be incorporated in the development of a set of modification factors.

Second, this report proposes a method to begin the definition of semi-quantitative m-factors for materials existing under various geachemicâl 
conditions in the earth's crust. These factors are defined on the Dasis of the mobility of geotoxic materials in the geochemical environment and are intended for use in the GHI deterinination.

Third, this report attempts to answer the question "what is the advantage of deeper disposal of radioactive materials?" If depth is not a significant factor affecting geochemical behavior of waste elements, then relatively snallow isolation can provide sufficient imnobility. Under these conditions increased depth is nat necessarily justifiatle fron a public health standpoint.

Information for this assessment of availability is drawn from an extensive geochemical literature search. Natural models forming the basis for radioactive analogs are the 0kTo fission reactors and uranium ore deposits; hydrothermal ore deposits of other metals provide analogs for stable toxic wastes.

An overview and salient insights derived follows:

1. The literature yields abundant geochentical information which could be used to describe the processes controlling the behavior and moverient of some geotoxic materials in the environment, namely, their availability. From tnis information, a group of geochemical parameters are chosen to represent factors controling waste component behavior. These include En, pH, mineralogy, presence of anions and cations, temperature and pressure.

2. Specific elements are selected to represent a waste package analog, particularly those deserving prime consideration as potentially mobile toxins. These include actinides, lanthanides, alkali metals, alkaline earths and others.

3. Results are presented in separate inatrices for mobility and immobility conditions. The analog condition for immobility of wastes is the 
deposition of materials as ores. For modility, the analog situation is solution transport of are materials to a concentrating point or dispersal.

4. Of the actinide elements selected for study, uranium has the greatest potential mobility. Conditions that minimize uranium mobility would imply minimized mobility of the other actinides.

5. The selected elements are discussed in terms of the effects of the geochemical parameters for both modilizing and immobilizing conditions.

6. The effects of the various geochemical parameters (En, PH, etc.) are discussed for the nost important group of elements, the actinides.

7. Sorption effects are significant, but certainly misunderstood, and perhaps over-rated as a subsurface barrier. They are discussed, but not dealt with as a matrix parameter, since sorption is affected by other geochemical parameters.

8. A table of proposed semi-quantitative $m$-factors, established on the basis of uranium mobility/immobility, is presented.

Major conclusions reached in this report are drawn from an analog approach to the geochemical behavior of a selected group of geatoxins. The geochemical literature proved to be the significant source of information rather than geologic or hydrologic data. The most important geochemical parameter for immobilization of most radioactive elements in most geologic environments appears to be the oxidation putential or Eh. A reducing environment would be generally desired for immobilization. Other immobilizing conditions are: moderate $\mathrm{pH}$, low $\mathrm{CO}_{2}$, low salt concentration, high porosity, and low permeability. Depth does not, in itself, appear to be an overriding consideration, since for some shales optimum immobilization via geochemical and tnermodynamic considerations can be achieved at relatively 
Snallaw deptris. The m-factors could be generally defined on the Dasis of mod 'lity as presented nertin, out not numerically quantified for sité-specific conoitions. The study of hydrothermal ores indicates that toxic oase metals beilave similarly, uut less preoictaoly, to the radionuclides in their stability under reducing conaitions.

Suggestions for furtner work include tile following.

a) Much analog data appears to be available from diverse sources, and needs to de collecteo.

4) The m-factors need to ve generalizeo to be easily applied to specific sitics. They also neeu to de more fully quantified.

c) Existing arilling data, giving geochenical information at various deptus, should be useu to more fully answer the deptn question.

d) Sedinentary basins should be examined to provide another analog datà source.

e) Geothermal studies, whicn could provide extensive metal mobility datà, should aiso be exwinined.

\section{ACKNOWLEUGEMENTS}

Iti- editor whshes to acknowledge the following people wro nelped with the final preparation of tilis report: C.F. Sllith and J. J. Cohen of Science Applications Incorporated, for reviewing the manuscript; D. Verrett for typing and correcting the text and tables; and especialiy S. Carey for typing corrections, tabie and figure layout, and report assembly. The authors take full responsibility for the technical content of this document. 


\section{PURPOSE AND REPORT ORGANIZATION}

This project was funded by Lawrence Livermore National Laboratory (LLNL) as a continuance of and contrijution to the Geotoxicity Hazard Index (GHI) develcis: at LLNL and described in Smith et al. (1980). That work took an "a $\because$ approach to the assessment of hazardous waste disposal. The analog approach, drawn in part from arguments formulated by $B$. Cohen $(e . g$. Cohen and Jow, 1978) and others, attempts to circumvent the apparently infinite "what if..." component of theoretical or deterministic modeling of waste/environment interactions. It also substitutes observation of natural phenomena for the mass of laboratory research data and assumptions used in deterministic or predictive modeling.

This report extends the availability tern of the GHI, specifically the m-factor as proposed by Sinith et al. (1980):

$$
\text { where } \begin{aligned}
m & =A_{j} / A_{0 j} \\
A_{j} & =\text { actual availability of material } i, \\
& \text { in a specific burial setting } \\
A_{0 i} & =\text { average availability of analog material } i .
\end{aligned}
$$

The purpose of this report is essentially three-fold:

a) to provide real world input from geological and geochemical sumnaries of existing observations of natural geotoxic element behavior in pertinent geologic environments. (Geotox ic elements include natural and man-made radioactive elements and certain non-radioactive metallic elements buried in the earth's crust).

b) to begin the definition of semi-quantitative limits (m-factors) on natural geologic processes affecting possible waste isolation sites or natural deposits of buried toxic material and, 
c) to attempt to answer the question "What is the advantage of deeper disposal of radioactive waste?"

This report is organized by sections. Section II, Approach, explains our arrival at a geochemical rather than a simple geologic or hydrologic approach to these tasks. Section II also sets our format and explains our choice of a matrix to guide the research work as illustrated in the total report.

Section 11 lists elements chosen to represent radioactive waste components. Selection of these representative elements considered:

1. those elements that are the most mobile and therefore the conservative proxy for their group;

2. those elements of significant half-life such as to be available to the biosphere over extended time periods; and

3. those elements for which some significant research is documented in che literature.

Section 11 lists and defines the aeochemical parameters of significance in either radioactive waste or toxic metal behavior. These oarameters are used tnen in conjunction with the selected waste elements above to form a matrix which sets the report format. Tables in Section II illustrate the final results of our work on radioactive elemenis as a capsule summary in matrix format, and another table represents an effort to quantify significant matrix relationships (quantification and semi-quantification of m-factors).

The report then elucidates the capsule matrix summaries in textual format. Information drawn from the $0 k 10$ natural fission reactors and from natural uranium deposits is discussed in Section III. Section IV then proceeds througn the matrix headings by groups of selected elements, discussing their relationship to geochemical functions drawn from the literature. 
Section $V$ reverses the process by examining effects in terms of the geochemical variables (Eh, pH, mineralogy, anion effects, and temperature) on a very significant group of radioactive elements, the actinides.

Sorption effects emerge as a significantly misunderstood topic deserving separate treatment (Section V!), thougn it was not dealt with specifically as a matrix neading.

Section VIl, Hydrothermal Om.s, deals with the analog potential of such deposits and of hot water systems in the mobilization/immobilization potential of metals. No matrix format or m-factor quantification was attempted for hydrothermal environments, but avenues for further work are clear. Similarities and dissimilarities of metal behavior witn the radwaste element geochemistry are noted.

Section VIII is a summary of geochemical benefits and problens of increased depth of radioactive and toxic waste burial, again in terms of mobility/immobility.

Conclusions and limits of all the proceeding work is presented by each individual author along with the potentially most rewarding analog-oriented work for the future. Note that two lists of references are included:

A. Radioactive Haste Behavior, and B. Hydrothermal Ores.

Appendices $A$ through $M$, present supplementary material included for technical verification of text and matrices, and for a more complete tecnnical Dackground. 


\section{APPROACH}

\section{A. Analog Application:}

Geology is rich in analog traditions with its origin as a science of natural observation in the field. But like other natural scientists, geologists are now taught to mistrust natural observation until thoroughly tested and understood in theoretical terms. Today, natural systems are reported in the literature as an intricate combination of empirical and theoretical observations with continuous building of "models" (e.g., the porphyry copper system; the plate tectonics systems; the geothermal systems) that are undergoing constant revision as they slowly approach understandable "reality".

This report has approached geotoxic interactions more through the perceptions of geochemistry than of the interactions of waste materials with the broad geologic terrain. The following comments describe our evolved direction:

1. Our initial approach relating actual rock types to waste isolation provided little definitive material useful for our purposes.

2. Rock type differences, in a broad sense, appoared to be relatively unimportant except where gross geochemical differences exist (e.g. salt vs. granite vs. organic shale).

3. Physical differences between rock types are primarily of hydrologic (porosity, permeability) or of engineering concern.

4. We were surprised by our early results indicating that even profound hydrologic parameters, such as extreme permeability and high solution flow-rates, may be less important than geochemical parameters. 
5. The literature indicates that others have firmly arrived at these same conclusions. The best work, a combination of theoretical and empirical geochemistry tied to geologic field observation, appears to have been done by Brookins (1980, 1979, 1978, 1976) and Langmuir (1978, 1977).

6. In simple geologic terms, 7ittle can be said to answer the question "What are we buying with depth?". Beyond the simple hydrologic variable (decreasing porosity/permeability plus increasing distance to biosphere), temperature and pressure effects lead us into a family of potent geochemical mobilization/immodilization possibilities.

The geochemical approach coupled with the pursuit of depth-related parameters seened to push us somewhat away from the analog approach and somewhat more into the theoretical than we had anticipated. This first-cut report is more complex, more scientifically illuminating, but less definitively reduced to the assessment format than we originally imagined.

B. m-Factor:

Tne $\mathrm{m}-\mathrm{f}$ actor as defined by Smith et al. (1980) includes both engineering, or engineered parameters as well as naturally imposed conditions of beneficial nature to waste isolation. For our purpose of focus, we separate the engineered parameters from the natural, and suggest that engineered parameters be considered separately in future hazard-indexing. This will help avoid confusion and temper the tendency to decrease the weight of natural barriers in a waste environment with assumed engineering solutions. 
Smith et al. (1980) define $m=A_{j} / A_{0 i}$, where $A_{j}=$ the actual availability for material $i$, and $A_{0 i}=$ a reference availability. In tnis report, we begin the development of a semi-quantitative set of m-factors by considering $m$ to be an estimate of the approximate influence of a given condition on the mobility/solubility of selected elements. A +m-factor implies an increase in mobility and a - im implies a decrease in mobility, with a zero m being the chosen standard corresponding to essentially immobile uranium species. Note that this notation is based on a logarithmic scaling in constrast to the original definition in Smith et al. (1980). Empirically, "immobility" may be assumed when molar concentrations of the species are at or below $10^{-11}$. As a first approximation $m$ is defined as $\log M / M_{r}$ where $M=$ molar concentration of a species and $M_{r}=$ the reference molar concentration $\left(10^{-11}\right)$ taken from the iminobile example $\left[\mathrm{WO}_{2}\right]^{++}$at neutral $\mathrm{pH}, 25^{\circ} \mathrm{C}$. The quantity, therefore, has a great deal of variation either above $(+m)$ or below $(-m)$ the reference $v$ alue $(m=0)$. Where quantification is not possible, mobilities are expressed as "+m (great, smal I etc." These first-cut symbols could be given as approximate values for purposes of semi-quantitative calculation.

\section{c. Format:}

We use a simple matrix to organize and summarize our work. Our selection of matrix-heading parameters forced us to focus on geochemical processes as the prime controllers of radioactive waste component behavior in the geosphere. Selection of headings also motivated selection of specific elements deserving prime consideration as mobile toxins. Taole 1 lists the elements selected for this study from the complete listings of Table 2 and Table 3. The geochemical parameters used as matrix rows are defined in Table 4. (Note: In order to maintain continuity in the text, all Tables are presented at the end of Section I I.) 
The matrix format, using elements as column headings and selected geochemical paraneters as horizontal rows, is illustrated in Table 5. Matrices were constructed for immobilizing and mobilizing corditions. Inmooilizing conditions represent the important situation where the stabilization of wastes is analogous to the formation of ore deposits. For mosilizing conditions, the movement of buried wastes is analogous to the situation where solutions transport ore materials to a concentration point, or to dispersal. These matrices are presented in Tables 6 and 7.

We originally intended to do a matrix pair for each significant rock type (e.g., granite, shale, salt, tuff, Dasalt) considered for radioa:tive waste isolation. This intent lead us to the somewhat paradoxical realization that the simple geochemical parameters dominate (or at least define witnin themselves) the differences between rock types.

Similar matrices could oe constructed for the hydrothermal ore [stable meta1) model. But our treatment of that area of study is introductory, so matrices and the quantification steps, m-factor tables, were not attempted for the nydrothermal systems.

Essentially, our report format is governed by the matrix organization. For radioactive materials two natural models or groups of models are examined through existing literature, for matrix input:

1. Ok lo Natural Fission Reactors

2. Uranium Ore Deposits
a. Coiorado Plateau-type
b. Vein-type

These models are discussed briefly in the text with additional referenced macerial given in appendices. Pertinent data is summarized in the 
mobilization and immobilization matrices (Table 6 and Table 7) and tnese matrix data are also discussed briefly in the body of the text as well as in referenced excerpts in the appandices.

Sorption requires text discussion in its own right, though it is dealt with throughout the matrix-based discussions. It was not chosen as a matrix heading, since sorption processes are controlled by the other geochemical parameters chosen as headings.

The matrices are working summaries of the radioactive element discussions. The m-factor Table 8 is a first attempt at summarizing semi-quantitative geocnenical relationships. 
TABLE 1. Components of Radioactive Wastes; Elements Selected for this Study.

Actinides (Th, U, Np.

Pu, Am, Cm)

\section{Lanthanides}

\section{Alkali Metals (cs)}

Alkaline Eartiss (Sr. Ba, Ba)

Other Metals (CO, Ni, SD. $\mathrm{Ru}, \mathrm{Fe}$ )

Technetiun

lodine
The actinide elements, especially U through Am, have analogous geochemical

behavinr. Althougn, thare are solle minor distinctions between the gencnemical buhavior of the actinides (which will be characterized in the matrix), generally uraniun has the greatest potential mobility. Conditions that minimize uraniun mobility would imply minimized mobility of the other actinides.

The Janthanide elenents have analogous yencheurical behavinr as a group.

Although some similarities do exist between the lanthanides and actinides, the aqueous cnemistry of the lanthanides is different frot that for the actinides. so the two groups are treated separstely.

This elenent nas a high potential mobility. The geolnucal toxic threat of ${ }^{337} \mathrm{Cs}$ (with a nalf-lite of 30 years) is aderated by $t$ ? short half life.

The activity of ${ }^{90}$ Sr with o half-litk of 28 years, is significantly reuuced after 600 vears. Radfurn-226 hecomes a significant waste component as $230 \mathrm{Th}$ decays. Radium-226 content of waste becomes significant after 50,000 years and increases for about $10^{5}$ years.

All have relatively shart half-7ives. $63_{\mathrm{Ni}}$ is the langest at 120 years.

Technetius-99, with a half-life of $2.1 \times 10^{5}$ years has a Mlatively higt potential mobility in its antonic form $\left(\mathrm{TCO}_{4}^{-}\right)$.

lodine-129, with a half-14fe of $1.7 \times 10^{7}$ years, has a hign pntential mobility and biological affinity. Its taxicity is mod. ated by its lous spectific activity. 
TABLE 2. Significant Nuclides in Radioactive Waste Management (from NEA, 1977).

\begin{tabular}{|c|c|c|c|}
\hline Nuclide & Half-life & $\begin{array}{l}\text { Major mod } \\
\text { of decay }\end{array}$ & $\begin{array}{l}\text { ilajar generation } \\
\text { mecnanisms }\end{array}$ \\
\hline Tritium & $12.3 y$ & $B$ & Fission and neutron capture \\
\hline [arbon-14 & $5.7 \times 10^{3} y$ & $\beta$ & Neutron capture \\
\hline Aryon-4l & $1.8 \mathrm{~h}$ & $\beta^{a}$ & Neutron capture \\
\hline Iron-55 & $2.9 \mathrm{y}$ & $E C^{b}$ & Neutron capture \\
\hline Conait-58 & $72 d$ & $\beta^{\mathrm{a}}$ & Neutron capture \\
\hline Cobait-60 & $5.3 y$ & $\mathrm{~B}^{\mathrm{a}}$ & Neutron capture \\
\hline Nickel-63 & $120 y$ & $\beta$ & Neutron capture \\
\hline Rrypton-85 & $10.8 y$ & $B^{a}$ & Fission \\
\hline Stront ium-89 & 510 & $\beta$ & Fission \\
\hline Strontium-90 & $28 \mathrm{y}$ & $\dot{B}$ & Fission \\
\hline Yttrium-91 & $59 d$ & $\beta$ & Fission \\
\hline Zirconium- 43 & $1.5 \times 10^{6} \mathrm{y}$ & $B$ & Fission \\
\hline Zirconium-95 & $64 d$ & $\beta^{\alpha}$ & Fission and neutron capture \\
\hline Niobium-95 & $35 d$ & $\beta^{\alpha}$ & Fission and daughter of Zirconiun- 95 \\
\hline Technetium-99 & $2.1 \times 10^{5} \mathrm{y}$ & 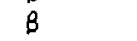 & Fission \\
\hline Ruthen ium- $100^{\circ}$ & $1 y$ & 3 & Fission \\
\hline Iodine-129 & $1.7 \times 10^{7} y$ & $B$ & Fission \\
\hline lodine-131 & $8 d$ & $\beta^{\mathrm{d}}$ & Fission \\
\hline Xenoni-133 & 5.20 & $\beta^{\mathrm{d}}$ & Fission \\
\hline Caes ium- 134 & $2.1 \mathrm{y}$ & $\mathrm{B}^{\mathrm{a}}$ & Fission and neutron capture \\
\hline Caes ium-135 & $2 \times 10^{6} \mathrm{y}$ & $B$ & Fission \\
\hline Caes ium-137 & $30 y$ & $B$ & Fission \\
\hline Cerium-141 & $33 \mathrm{~d}$ & $\beta^{a}$ & Fission \\
\hline Cerium-144 & $285 d$ & $B^{*}$ & Fission \\
\hline Promethium-147 & $2.6 \mathrm{y}$ & $B$ & Fission \\
\hline Samarium-15l & $93 y$ & $\beta$ & Fission \\
\hline Europium-154 & $16 y$ & $\beta^{\mathrm{a}}$ & Fission and neutron capture \\
\hline Lead-210 & $22 y$ & $B$ & Oaughter of Polonium-214 \\
\hline Radon-222 & $3.8 \mathrm{~d}$ & $\alpha$ & Daughter of Radium-225 \\
\hline Radium-226 & $1.6 \times 10^{3} y$ & $a^{\mathrm{a}}$ & Daughter of Thorium-230 \\
\hline Thor ium-229 & $7.3 \times 10^{3} \mathrm{y}$ & $\alpha^{3}$ & Daughter of Uranium-233 \\
\hline Tnor ium-230 & $8 \times 10^{4} y$ & $\alpha$ & Daughter of Uranium-234 \\
\hline Uranium-234 & $2.4 \times 10^{5} y$ & $\alpha$ & Daughter of Protact inium-234 \\
\hline Uranium-235 & $7.1 \times 10^{8}$ & $a^{d}$ & Natural source, daugiter of Plutonium-23y \\
\hline Uran ium $=238$ & $4.5 \times 10^{9} y$ & $\alpha$ & Natural source \\
\hline Neptun iun-237 & $2.1 \times 10^{0} y$ & $a$ & $\begin{array}{l}\text { Neutron capture and daughter of } \\
\text { Anericium-241 }\end{array}$ \\
\hline Plutonium-238 & $87 y$ & $a$ & $\begin{array}{l}\text { Neutron capture and daughter of } \\
\text { Curium- } 242\end{array}$ \\
\hline Plutanium-23y & $2.4 \times 10^{4} \mathrm{y}$ & $\alpha$ & Neutron capture \\
\hline Plutonium-240 & $0.6 \times 10^{3} y$ & $\alpha$ & Neutron capture \\
\hline Plutonium-241 & $15 y$ & B & Neutron capture \\
\hline Pluton ium-242 & $3.87 \times 10^{5} y$ & $a$ & Neutron captire \\
\hline Americium-24l & $433 y$ & $\alpha$ & $\begin{array}{l}\text { Neutron capture and daugnter of } \\
\text { Plutonium-241 }\end{array}$ \\
\hline Ainer ic ium-243 & $7.37 \times 10^{3} \mathrm{y}$ & a & Neutron capture \\
\hline Curium-242 & $163 d$ & $\alpha$ & Neutron capture \\
\hline Curium-244 & $18 \mathrm{y}$ & $\alpha$ & Neutron capture \\
\hline
\end{tabular}

a) With associated penetrating gamma radiation.

b) $E C=$ orbital electron capture. 
TABLE 3. Initial Radionuclide Concentration of Input Solid Wastes (from Chipman et al., 1980).

\begin{tabular}{|c|c|c|c|c|c|}
\hline Nuclide & $\begin{array}{l}\text { Activity } \\
\text { (Ci/kg) }\end{array}$ & Nuclide & $\begin{array}{l}\text { Activity } \\
(\mathrm{Ci} / \mathrm{kg})\end{array}$ & Nuclide & $\begin{array}{l}\text { Activity } \\
\text { (Ci/kg) }\end{array}$ \\
\hline${ }^{73} \mathrm{Se}$ & $6.4 E-05^{*}$ & $87_{R b}$ & $3.6 E=09$ & ${ }^{90}{ }_{S r}$ & $1.3 E+01$ \\
\hline $90 \%$ & $1.3 E+01$ & $93_{2 r}$ & $3.15-04$ & $93 m_{N b}$ & $7.5 E-05$ \\
\hline${ }^{99} \mathrm{TC}$ & $2.1 E-03$ & $106_{R u}$ & $9.7 E-01$ & ${ }^{106}{ }_{R h}$ & $9.7 E-0 ?$ \\
\hline $167 \mathrm{Pd}$ & 2.0E-06 & $126_{S n}$ & $3.2 E-05$ & ${ }^{126 \mathrm{~m}_{\mathrm{Sb}}}$ & $3.2 E=05$ \\
\hline${ }^{126} \mathrm{Sb}$ & $3.2 E-05$ & ${ }^{134} \mathrm{Cs}$ & 3.3 & ${ }^{135} \mathrm{cs}$ & $7.5 \mathrm{E}-05$ \\
\hline${ }^{137} \mathrm{Cs}$ & $1.3 E+01$ & $137 m_{B a}$ & $1.2 E+01$ & ${ }^{144} \mathrm{Ce}$ & 8.2 \\
\hline${ }^{144} \mathrm{Pr}$ & 8.2 & 144 Nd & $0.0^{\text {t* }}$ & $147_{P m}$ & $1.2 E+01$ \\
\hline${ }^{147} \mathrm{Sm}$ & $0.0^{\text {t* }}$ & $151_{S m}$ & $1.7 \mathrm{E}-01$ & ${ }^{154} E u$ & $1.8 E-01$ \\
\hline${ }^{226} \mathrm{Rd}$ & $0.0^{* *}$ & ${ }^{230}{ }_{T h}$ & $0.0^{* \star}$ & ${ }^{233} \mathrm{~Pa}$ & $0.0^{* \star}$ \\
\hline $233 \mathrm{U}$ & $1.2 E-12$ & ${ }^{234} \mathrm{U}$ & $4.3 E-10$ & $235_{U}$ & $1.8 \mathrm{E}-09$ \\
\hline $236 \mathrm{v}$ & $1.0 E-08$ & $237_{U}$ & $4.8 E-12$ & $238_{U}$ & $1.0 E-14$ \\
\hline $237 \mathrm{~Np}$ & $4.8 E-0 B$ & ${ }^{239} \mathrm{~Np}$ & $0.0^{\star \star *}$ & ${ }^{23 B_{P u}}$ & $7.0 \mathrm{E}-02$ \\
\hline${ }^{239} \mathrm{Pu}$ & 7.OE -04 & $240 \mathrm{pu}$ & $6.5 E-04$ & $241_{\mathrm{Pu}}$ & $1.6 E-01$ \\
\hline${ }^{242} \mathrm{pu}$ & $1.8 E-06$ & $241_{\text {Am }}$ & $9.8 E-04$ & ${ }^{243} \mathrm{Am}$ & \\
\hline${ }^{242} \mathrm{Cm}$ & $6.5 E-04$ & ${ }^{244} \mathrm{Cm}$ & $5.2 E-04$ & & \\
\hline Total & $8.5 E+0 !$ & & & & \\
\hline
\end{tabular}

$\star 6.4 E-05=6.4 \times 10^{-5}=0.000064$.

* Initial input is 0.0 , but they appear later as daughter products. 
TABLE 4, libubilization/Mnoilization; Genchenical Paranleters used as Matrix Headings.

The various controls on the ph in the near-suriace environment include cation and anion crincentration from interaction wich minerais (especially tnose yielding carbonate ion, silica and sulfuri, decaying organic thatter and dissolved salts wnich can act as buffers. In deep envirnnments pH is determined by tne mineralogy of the rocks tnemselvas.

Eh - Coxidatinn/ reuuction pntential)

Oxidation/reduction is the single most inportant factor affecting mollity, especidily of the detinides. Fajor controls of Eh in the near-surface environment are caronn content, $\mathrm{Fe}^{+3} / \mathrm{Fe}^{+2}, \mathrm{~S}^{-2} / \mathrm{SO}_{4}^{-4}$ and $\mathrm{P}_{\mathrm{U}}$ (partial pressure of axygen). The envirnnmental En range is defined by $P_{02}(E n=1,22-0.059 \mathrm{pH})$ ano $P_{\mathrm{H} \text { : }}$ (Eh $=-0.059 \mathrm{pH})$.

Carbonaceous matter may permit stmnyer local reducing reactions. There is aiso evidence to suggest that secondary mineral genes is (alteration) may be a factor in the reduction of uranium in sedimentary ore deposits.

Mineralogy

The mineralogy of a given rock type can stgrificantly influrnce the behavior nf waste cnmponents, especially adsorption cnaracteristics, Eh and $\mathrm{pH}$.

Presence of anians The presence and concentration of anions, like $\mathrm{Cl}^{-}, \mathrm{F}^{-}$. $\mathrm{CO}_{3}^{-2}, 4 \mathrm{PO}_{4}^{-2}$ and $\mathrm{SO}_{4}^{-2}$ can influence the solubility and adsarption of inaste materials grossly througn the very iinportant out pnorly understnou processes of complex formation.

Presence of Cations The presence and concentration of cations sucn as $\mathrm{Na}^{+}, \mathrm{K}^{+}, \mathrm{Ca}^{+2}, \mathrm{Mg}^{+2}, \mathrm{~V}^{+5}$. Can influence the adsorption of wiste materials by conpeting for both ion exchange and enmplexing sites.

Temperature

Elevated temperatures, resuiting from radinactiva decay will influence both the mechanical and chemical priperties of the rock and waste naterial. Whate heat will alsn set up pressure gradients and convection cells in the ground water around a repositary. Heating effects on the mechanical properties of rock are currently being investigated at some of tite pilnt repnsitory sites, i.e., Strips, Hanforo and the Nevad, Test site. The chenical effects are difficult to quantify. As a very general rule, a $10^{\circ} \mathrm{C}$ increase in temperature approxinately onubles or triples ine reaction rate. Solubilities will increase if dissnlution is endotnernic and vecrense if dissolution is exothernic. Under the right chenical conditions, increased reactinn rates, due tn the elevated

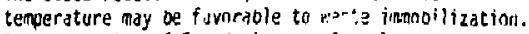
Interpretation of En-prl oiagraris for elevateo temperatures is prnolematic because nast of the aata for construction of these viagralas are based on surface envirannent (approxinlately $25^{\circ} \mathrm{C}=40^{\circ} \mathrm{C}$ ) enditions.

There is generally insignificant cnarige in solubility of liquias and solids with pressure. The solubility of all gasos is increased as the partial oressure of the gas is increased in praximity of a solutinn. Intreases in the partial pressure of $\mathrm{CO}_{2}$ illay significantly affect actinide mobility and, of course, the gartial pressure if $\nu_{2}$ greatly intluences ine nxiadtinn pntential. 
TABLE 5. Matrix Summary Format.

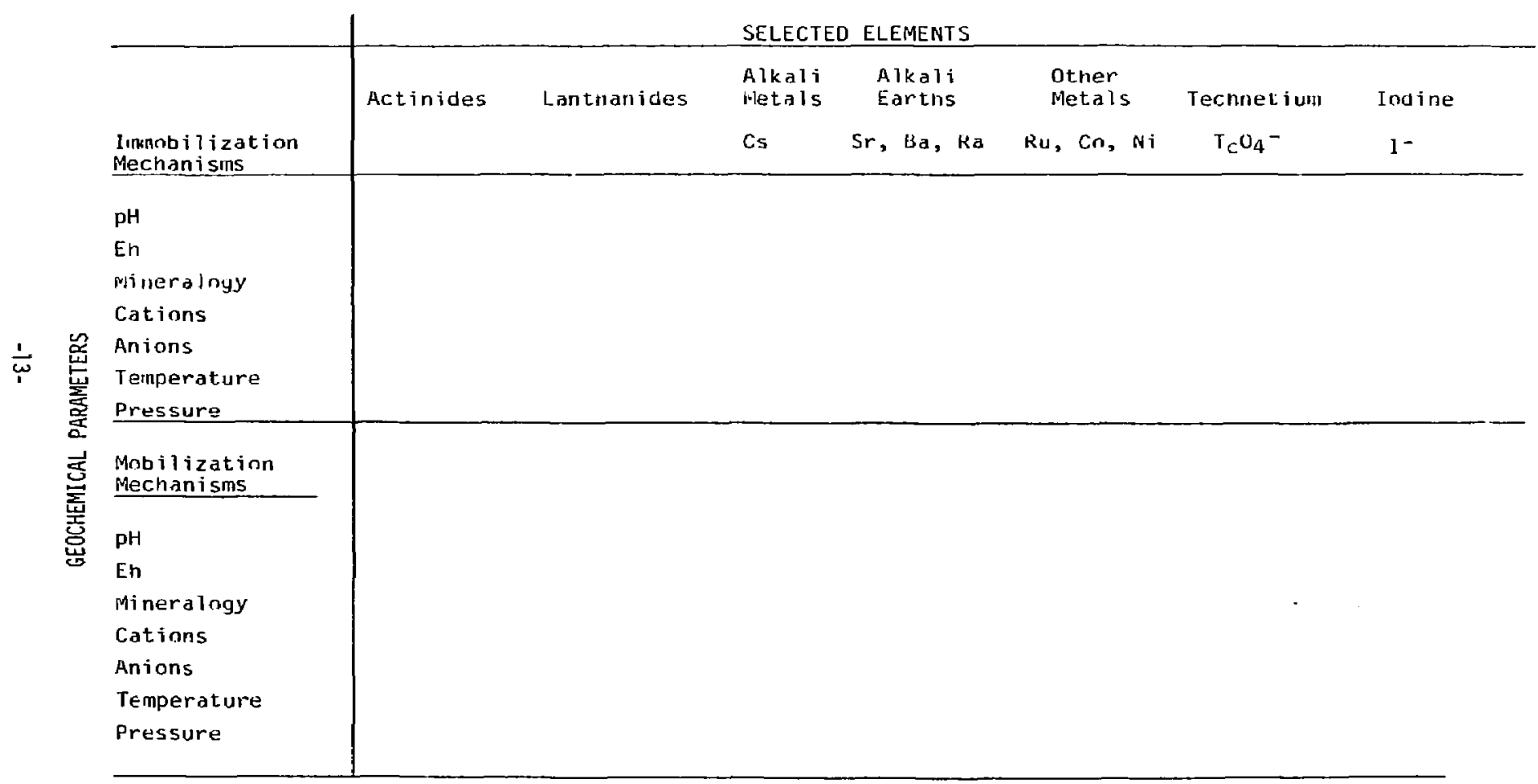


(BLANK PAGE)

$-13 a-$ 
JeELE 6. Hobllinat lon of Selested pucliaes in Geocheaical Enviroments.

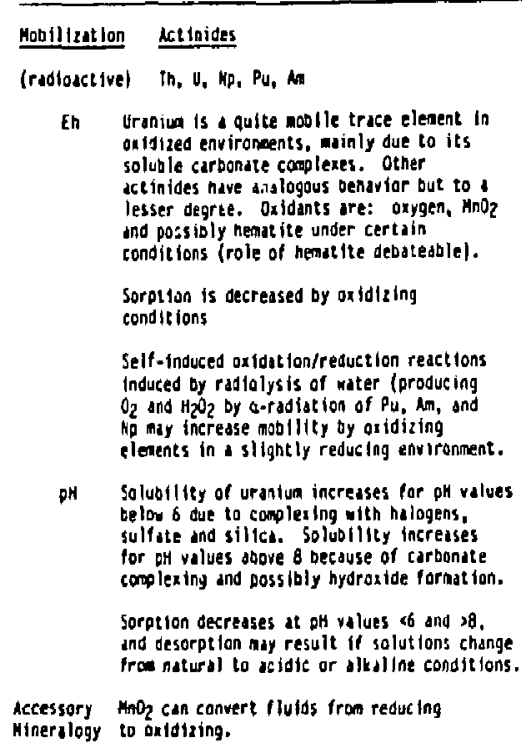

Salts enhance solubility and decrease sorption capacity.

Act Inides have a strong tendency to $\mathrm{rom}$ complexes.

Complenes inhibit sorption and favor desorption.

Presence

The ur unyl carbonate complexes ore the single most inoortant factor contributing to uraniua noblitity in ondized environnents. The mobllizing effeces of carbonate complexes increase it ph values above $\theta$ and for high partid? pressures of $\mathrm{CO}_{2}$. Very high $\mathrm{CO}_{2}$ pressures ilso increase the solubility of the very 1) scluble uranous specles. Carbonate complexes are signif leant under oxidiz iag condtions when oH values exceed 5 and temperature $<100^{\circ} \mathrm{C}$.

HPOl complexes are probably the second most important nobilizers of uraniun under nearsurface or oxidizing consilions. MPOj complexes are most significant for PH 6 to $B$

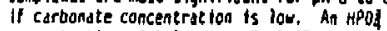
concentration of 0.1 ppis at Eh=0.05v and pHa 6 enhances both the solubility of uranous ind uranyl species.

Sol complexes are signiflcant below pH-3 and may be imporiant up to oHci for sulfate concentration $\$ 100 \mathrm{ppa}$,

Fluor sate cooplenes with urantu bre very important at pH ş even at elevateo temperatures.

Silica coaplexes are signlficant de oH 6 if coj and UPOL are low.

Hydroxide complenes aby be signtfleant at ph values 3 B.

Presence of Increasing tation concentration generslly Catlons reduces sorption capactiy, Dissolyling waste connisters are a potential source of cations.

\section{Lanthanides - Rare Earths}

(2)

Solts in solution inhibit lanthanide sorption on clay.

Increased concentrition of tha and ca decreases sorption of rare eirtins on kablinice ind moptingriflonite.

$\frac{\text { Alkall-HeGuls }}{C_{S}} \quad \frac{\text { Alraline Eurth }}{S_{r}, B_{1}, R a}$

Sone experibental evidente sowe experinental suggests that Cs sorotion suggests that $5 r$ on luff and shale is generally less from deDrygenated. Ho such de- shale is generall fron de-axygenate granite.

Radiun concentrat apparently incres appartently increabecause of disso? Re Itself but rat to dissolution of hydroxilues on thi. RI is adsarbed.

Mo Cs sorpt ton fron Stavlated orine solution for ph values between 6.5 to 7.9 and no sorption froe grcund water for oH volues of 7.5 to 8.2 .

Sorgt lon of Cs decreised fron solut tans of hiph dissolved salits.

Crystalline tron and manganese oxides and hydrorides shamed no sorption of $[s$.

Sorpt ton of $\mathrm{Sr}$ decreased from so of high dissolved of ph values 6.5

Radiun concentrot Increased ten to hundred $t$ Imes du comolexing with brine solut ions.

hollized under pressure 103 is postulated froa carbonat lte aralo

Both $X^{+}$und int compte ith $6 s^{*}$ for sorpt lon sites, and therefore inhlitit is sorption.
$\mathrm{Ma}, \mathrm{Mg}^{+2}, \mathrm{Ca}+2$ tration decrease sorpt lon by conp for sites.

Utte discrinin Ajsr and $4 \mathrm{Cl}_{\mathrm{i}}$ in precipitation or exchange in soll 


\begin{tabular}{|c|c|}
\hline - Metuls & Aluline Eurths \\
\hline 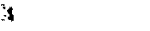 & so : $8 u_{1}, \mathrm{Ru}$ \\
\hline $\begin{array}{l}\text { loental evidenes } \\
\text { hat Cs sorption } \\
\text { d shale is } \\
\text { lest frod de- } \\
\text { ka sueh } \\
\text { eg for granite. }\end{array}$ & 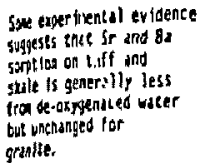 \\
\hline & 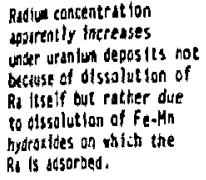 \\
\hline
\end{tabular}

iton fras

brine solution

ives betreet

! und na sorption

other Hietdis

Iechnes fot

$\mathrm{Ru}_{2}$ CO. $\mathrm{HI}$

$7 \mathrm{CO}_{4} \mathrm{M}$

lodine

7,5 to 8.2 .

Aclolic ph values increasa

nablilty.

$$
\text { I" }
$$

if ls decreised ilons of high silts.

ne iron uno oxides and s snared na of $\mathrm{Cs}$.
Sarptlon of Sr and Bd decrused from solutions of tigh alssolved salts at of yelues 6.5 to 1.4
Hunic acld gpperently incioits Coto sorpt ion.

Sorpt lon on clays and rack materials very low in oxidizing solut lont. lecon atgrate in halides by olffusion.
Raslua concentration increased ten to jever al tuadied tínes due to toeplexiag witn 6$)^{-}$in orite solutions.

Natlined whot high $\mathrm{CO}_{3}$ pressure $\mathrm{COH}_{3}$ as postulated from the carbanalste andiog.
Mitrite lons serongly to form neutral ond to form neutral snd which ure very noblite.

lead is relatively innobile in the presence of sulfate and sulfice.

Ru foras numerous comlexes with haliaes.
Ko sorplien of $\mathrm{TCO}_{4}$ " from brine solutions at $\mathrm{pH}-6.5$ to $\mathrm{B.2}$

Chentstery of TC in complexes has beed relatualy little studied, but resenoles rhenisan.
Ho iorptlon of 1 " frat brine solution It $\mathrm{pH}=6.5$ to 8.2 snd mi" couptete for sorption id therefore
is sorption.
$\mathrm{HA}^{+}, \mathrm{Hg}^{+2}, \mathrm{Ca}^{+2}$ conethtrition decrease $5 T$ seration by competing Ior sites.

Jytle oigcrialinat foh between

ast and ifes in elther preciofition or ection cenmge in soils. 


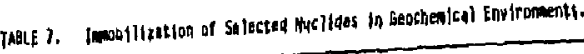

\begin{tabular}{|c|c|}
\hline & 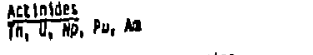 \\
\hline \multirow[t]{2}{*}{ Ed } & 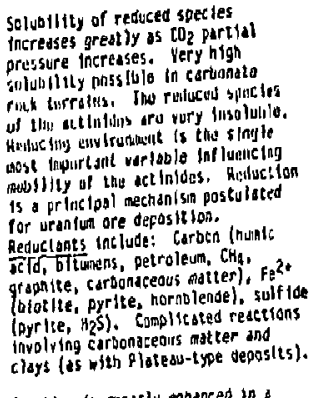 \\
\hline & 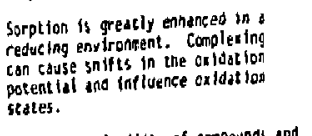 \\
\hline $\mathrm{pH}$ & 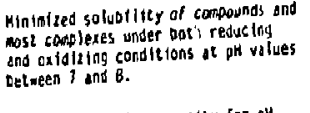 \\
\hline & $\begin{array}{l}\text { Masinized sorption capacity for ghl } \\
\text { values oet ween } 6 \text { and } B, 5 \text {. }\end{array}$ \\
\hline $\begin{array}{l}\text { Accessory } \\
\text { Mineralogy }\end{array}$ & 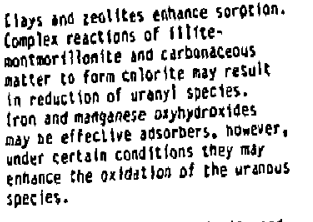 \\
\hline & 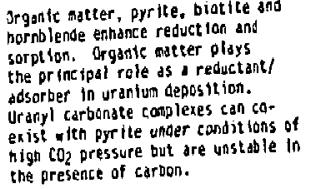 \\
\hline
\end{tabular}

Aegox chardecerist lics of actessory ainerals strongly inf luence the oxfotion state for the actinides.

presence of voj favors precipitation of crinotite antons

In an octaizing envitrongent with

$\mathrm{CO}_{2}$ pressure (atmospheric). At atmosphertc $\mathrm{CO}_{2}$ Pressure ind a $\mathrm{PH}$ doboul 7, sutunite agy precipltate if [HPOA] 30.1 ppin and [voj] is less tman 500 that of chenl. Genersting an imosilization.
Lenthucides - Riure Eurths

The reduced spectes of the lanthanides are generally andlogans to the det inloes and are very Insolutele.

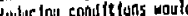

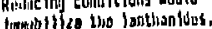

Sorpt lon is higher for Ce and Eu under de axygenated conoltions.

Hax Inum sorpt ton at nesurta $\mathrm{PH}=6-8$.

(5) seppt los on "saect fle" clay is not allect by pH,

Go ts adsorbed anto chlorite,

Lanthanides adsorbed on to crusined grentte, bentonst and red clay.

Prefereneial fludion of la and $\mathrm{Ce}$ into calcerous sediments due to similar gonic radi due to similar $\mathrm{Ca}^{+2}$. [e $e^{+4}$ miy of removed by copreclpitation with ferro-manganese nodules.

Lunthintdes bond dinost exclustuely in tonte matier and have virtually no complexes or covsient compounds. expected fron theit
Alkul1 - Hewil
A. low consenteations of Cs. sprptlos otto tlay is igh out dacreases whth increasing cs concentration.

Huinte detd is a good Cs itsorber.

Sorption of cs en verateullete for is supertior to nontergrillonite but not if goos as 2 equlites. Sam Sordtion and flusenin sepend cla an $(C S)$ and the charge tensity of the erystal layers.

Sorption and flation capdetcies for mixtures of clays, destifes and on Joj byaroxiats ate gredtef thin en be indiuidual sorptios capactetes. Jasprobhyre dtke intruding on evaporite suggests thi the lanthasides rendined canfined is tha fimediate confined 25 the the during and ared of the dike durtiog enplacemens. Orystill fine phises appat
St
Incredsed tempriturts increised ls retention on 'seet fite' sly.

at 200'C and aldowe, ker in shite. Polluctie (Csals 006 ) appears as a doalanint reketion pedduce since shdies are illall poor ind should act is poor ind ghor ledil scavengets for dist elevents to rent with clays to fars fracorth silicates, lieis. 


Ifthis
of the
rally
=Inides
iff.
rould
anitust.
or
is.
neutrol

$\frac{\text { Alkaline Eurems }}{J_{1}, d_{1} R d}$

clay is not efrect by ph.

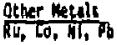 \\ Reduc ing condit Ions \\ returd lu mobllity \\ in brine solutions, \\ possibiy by formation
of sulfide or hydros lat. \\ technetsis \\ $\mathrm{TCO}_{4}$ \\ ic $\mathrm{c}^{+4}$ is sparingly soluble \\ in reducing condit lons.}

losine

Reducing conditions

sorption.
St fixation is muen grester in wlxtures of zeolitas than can be expecles fros the

ind fuldusl monters. iolite with mardenfte or phillipsito is best

Sorption of cs on veralculite for 55 sorptlon.

bus super lar to mantmor

sorption and fablion depend thays.

on [Cs] and the charge densley

of the crystsi ldyers.

Sare hunic acid gromotes

Sr sorption.

Sorption and fluation idpacit tes for mixtures of ciays, deolites and oxice/hyoroulose are greater than can be expected from the is insividual sorption capuefties.

foutum ansorbed nore than St on granite and bentonte cernaos because the Raso soludilley orogust is lamer then for $\mathrm{Sr}_{50 \mathrm{~A}}$
Ras louy conrentrations of

$5 r+2$ in ground water is

inited oy preciattation

of the insoluble carbonate.

Ho $5^{5} \mathrm{O}_{4}$ has been proposed as

sis cholster overosck aterial

to Jintt Sr obolitity in brine

efil irosaents.

Maxinuti concentration of $R$

lin ground water llaited by

precipication of the 1nsoluble

sulfate

Aadrum coprecipitates atth

fd- and Haccarbonates.

\section{Huinjc ic id proweres}

Te0z was tosarbed on shale under outdialng iil is eariched in clays the oritions, probably usseclated with wrentus depostls.
Iron and Al-nydrosides,

clay, Cu, Po and Ag

compounds atsoroed i

froo reduced ground

ater.
Reduced $\mathrm{CO}_{2}$ content wy enhance Ted tetardation.
I absorbed on galent and copper netal under redueing conditions lacressed cewperatures Increased Cs retent Ion

At 200"t ind above, new Orystalline ohates apear in shite. Pollucite \{CsR $\left.S_{2} 0_{6}\right\}$ ippears is a dominant redetion product. since shales are alkali. poor and shouls act as poor and should act as scavengers for ditult clements to recti with
cluys to fora fruework stlicates, 1.t., zeolices ind/or feldspars. 
(BLANK PAGE)

$-15 a-$ 
TABLE 8. m-Facturs: Factors That Affect the Mobility of Urantum.

Each m-factar represents a comparison to a set of reference conditions, given at the oeginning of each section.

Conditions

Given reducing canditions (Eh below $0.273 \mathrm{v}$ at $25^{\circ} \mathrm{C}$; uranium is in the +a

0.01 pt exce.

water pH values (4-8) makes uranium practically immobile in low Eh environ

o pH $=7,\left[\mathrm{UO}_{2}\right]=\sim 0.01 \mathrm{ppb}$ or $\left.1 \mathrm{~g}^{-1}\right]_{\mathrm{M}}\left[\mathrm{UO}_{2}\right]$ a $25^{\circ} \mathrm{C}$

e $\mathrm{pH}=9,[\mathrm{U}]=\sim 1 \mathrm{ppb}$ or $10^{-9} \mathrm{M}\left[\mathrm{UO}_{2}\right]$

$0 \mathrm{pH}=4,[\mathrm{U}]=\sim 0.0001 \mathrm{ppb}$ or $10^{13^{3}}\left[\mathrm{UO}_{2}\right]$

$0 \mathrm{pH}=2$. $[\mathrm{U}]=20.01 \mathrm{ppb}$ or $10^{-11} \mathrm{M}\left[\mathrm{UO}_{2}\right]$ lan-fold increase in uraninite solubility ot $\mathrm{pH}=6$ and $\mathrm{PO}_{4}=0.1 \mathrm{ppin}\left(10^{-6} \mathrm{M}\right)$

1000-fald increase in uraninite solubility with a rise of $\mathrm{P}_{\mathrm{CO}}$ from atmospherte

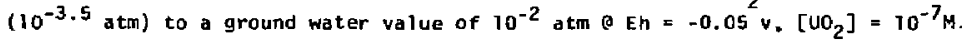

Uranous fluoride complexes are stable up to $\mathrm{pH}=4025^{\circ} \mathrm{C}$, at $2 \mathrm{ppm}[\mathrm{F}]$ and
$\mathrm{pH}=2$.

Solubility of uraninite increases about tenfold as temperature tncreases from

Well crystallized uraninite is much less soluble than amo phous $\mathrm{UO}_{2}$ (pitcholende).

\begin{tabular}{|c|c|}
\hline $\mathrm{m}$ & Reference \\
\hline & Langmule (3978) \\
\hline 0 & Langmuir (1978) \\
\hline+2 & Langmuir (1978) \\
\hline-2 & Langmuir (3978) \\
\hline o & Langmuir (1978) \\
\hline+2 & Langmuir (1978) \\
\hline+3 to +4 & Langmuir (1978) \\
\hline+6 & L sngnuir (1978) \\
\hline+1 & Langmuir (1978) \\
\hline-2 to -6 & Langmuir (1978) \\
\hline
\end{tabular}


TABLE - - CONT INUEO

Conditions

So:ubllity of uraninite increases with temperature with maximum solubility at $260^{\circ} \mathrm{C}$ in pure water.

(a $25^{\circ} \mathrm{C},\left[\mathrm{UO}_{2}\right]=\approx 0.01 \mathrm{ppb}$

(a $100^{\circ} \mathrm{C},\left[\mathrm{UO}_{2}\right]=\approx 0.1 \mathrm{ppb}$

(c) $260^{\circ} \mathrm{C},\left[\mathrm{UO}_{2}\right]=\sim 75 \mathrm{ppm}$

Background values for uranium in streams is around 0.1 ppb. In uraniferaus areas, the uranlum concentration in waters can range from 1 to 400 ppb. (m-factor is $11 \mathrm{M}$ ) expressed relative to the concentration of uranintte in pure water a $25^{\circ} \mathrm{C}\left(10^{-1} \mathrm{M}\right)$.

[Carnotite] $=10^{-7} \mathrm{M}$ a $\mathrm{pH}=7$ and $\mathrm{P}_{\mathrm{CO}_{2}}=10^{-2}$ atm $025^{\circ} \mathrm{C} \mathrm{w} / 0.1 \mathrm{ppm}$ vanadium $10^{-6} M$ vanadatel

[Carnotite] $\times 10^{-9} \mathrm{M} O \mathrm{pH}=7$ and $\mathrm{P}_{\mathrm{CO}_{2}}=10^{-3.5} \mathrm{~atm}$

[Tyuyamunite] $=10^{-6} \mathrm{M} \mathrm{pH}=7$ and $P_{\mathrm{CO}_{2}}=10^{-2} \mathrm{~atm}$

[Tyuyamunite] $=10^{-\mathrm{B}} \mathrm{M} \mathrm{pH}=7$ and $\mathrm{P}_{\mathrm{CO}_{2}}=10^{-3.5} \mathrm{~atm}$

Solubility of carnotite and tyuyanunite increases above $\mathrm{pH}=8$ because of farmation of carbonate complexes.

[Autunite] $=10^{-4} \mathrm{MOPH}=7$ and $\mathrm{P}_{\mathrm{CO}_{2}}=70^{-2} \mathrm{~atm}$

$\Sigma \mathrm{PO}_{4}=10^{-6} \mathrm{M}(0.1 \mathrm{ppen}) ;[\mathrm{Ca}]=80 \mathrm{ppm}$ or $10^{-2.7^{\mathrm{M}}}$ and $[\mathrm{K}]=39 \mathrm{ppm}$ or $10^{-3} \mathrm{H}$.

[Autunite] $=10^{-6}$ to ${ }^{-7} \mathrm{M} \mathrm{O} 2 \mathrm{pH}=7 ; \mathrm{P}_{\mathrm{CO}_{2}}=10^{-3.5} \mathrm{M}$. Ground waters from granitic terrain were more 1 ikely to have a $\left[\mathrm{PO}_{4}\right]$ of $0.1 \mathrm{ppm}$ or more as compared to

[uranyl hydroxide] in slightly alkaline and slightly acidic solutions is about

Reference

Langmu ir (1978)

$+1$

$+5$

Langmutr (1978)

Langmuir (1978)

Langoulits $(1978)$

Langmuir (1978)

Langmuir (1978)

Langmuir (1978)

Langmuir (1978)

Krauskopf (1967) 

[uranyl carbonate] complexes at pH $=7$ with $0.01 \mathrm{M}$ [carbonate] is $10^{-4} \mathrm{M}$ a $25^{\circ} \mathrm{C}$

Uranyl Carbonate Complexes:

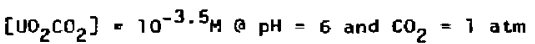

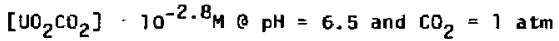

$\left[\mathrm{UO}_{2} \mathrm{CO}_{2}\right]=10^{-2.3} \mathrm{M} \mathrm{O} \mathrm{pH}=3$ and $\mathrm{CO}_{2}=1$ atm $25-50^{\circ} \mathrm{C}$

$\left[\mathrm{UO}_{2} \mathrm{CO}_{2}\right]$ with $\mathrm{NaHCO}_{3}$ exceeds 10,000 ppm at low temperatures At $\mathrm{CO}_{2}$ pressure of $10^{-2}$ atm and $25^{\circ} \mathrm{C}$ the uranyl carbonate complexes are the
major species in pure water down to a pH $=5$.

Ui anyl fluoride complexes up to $\mathrm{pH}=6.7$ e $25^{\circ} \mathrm{C}$

Uranyl sulfate complexes stable up to $\mathrm{pH}=4$ possibly significant up to $\mathrm{pH}=7$. Uranyl silica complexas a pH $=6$-accounts for up to $50 \%$ of the soluble uranium
species with $510_{2}=60 \mathrm{ppm}$ or $10-3 \mathrm{M}$.

Uranyl chloride complexes: neutral solutions saturated with respect tn $\mathrm{UO}_{3} \cdot \mathrm{H}_{2} \mathrm{O}$ or $\mathrm{UO}_{3} \cdot 2 \mathrm{H}_{2} \mathrm{O}$ contains 70 ppr urantum which increases in dikaline and greatiy increases in actdic solutions.

Carbon, carbonaceous matter and/or methane.

Sulfide (pyrite, $\mathrm{H}_{2} \mathrm{~S}$ ).

$\mathrm{Fe}^{+2}$ (i.e., biotite, augite).

Presence of the above reducing agents will generally decrease the solubility to below the decection limit.

Reduction of $u$ due to metanorphic rear tians involving the oxidation of ferrous ion and resultant reduction of uranyl ion.

Reduction of uranium during clay mineral formation.
$+9$

krauskopf (1967)

Rich, et al. (1975)

Rich, et al. (1975)

Rich, et al. (1975)

Rich, et al. (1975)

Langmuir (1978)

Rich, et al. (1975)

weak

Langmuir (1978)

$\stackrel{+m}{\text { moderate }}$

Langmuir (1978)

+6 to
$\rightarrow+6$

very strong

strong

moderate to strong

Langmuir (3978)

kangmuir (1978)

Langinusir (1978)

McMillan (1978) 
TAGLE 8 - CONTIE! IED

\section{Conditions}

Sorption of 1 ppm uranium $\mathrm{pH}=5$ to 8

$$
\begin{aligned}
& \text { a } \mathrm{pH}=4 \\
& \mathrm{pH}=9 \text { with } \mathrm{CO}_{2} \\
& \mathrm{pH}=9 \text { without } \mathrm{CO}_{2}
\end{aligned}
$$

Presence of sulfate, halogens, or carbonate inhibits sorption.

Humic acid concentrates uranium 10,000:1 $\mathrm{pH}=2,5$.

Sarption agents:

carbon

zealites

clay

\begin{tabular}{|c|c|}
\hline m & Reference. \\
\hline 0 & Langmuir \{1978) \\
\hline+2 or & Langmuir (1978) \\
\hline & Langmuir (1978) \\
\hline 0 & Langmutr $(1978)$ \\
\hline$+m$ & Langmuir (1978) \\
\hline$\stackrel{-m}{\text { strong }}$ & Dyck $(1 ; 78)$ \\
\hline strong & Brookins $(1980)$ \\
\hline $\begin{array}{l}-m \\
\text { strong }\end{array}$ & Sralay (1967) \\
\hline$\stackrel{-m}{\text { moderate }}$ & $\begin{array}{l}\text { Shiao, et a). }(1979) \text {. } \\
\text { Beall, et al. }(1979)\end{array}$ \\
\hline$\stackrel{-m}{\text { maderate }}$ & Haire Beall (1979) \\
\hline $\begin{array}{l}\text {-mis } \\
\text { weak }\end{array}$ & Allard, et al. (1980) \\
\hline
\end{tabular}

augite and biatite

oxides 


\section{NATURAL MODELS FOR RADIOACTIVE WASTE BEHAVIOR,}

\section{A. OKlo Natural Fission Reactors (General):}

The existence of well-preserved natural fission reaction sites such as thos? at $0 k 10$ provide the best possible natural analog for the geologic Dehavior of a modern radioactive waste mix.

Oklo originated geologically as a urinium deposit in sedimentary rocks probably analogous to the mucn younger Colorado Plateau-type ore deposits, (Brookins, 1978) except that concentrations of fissionable uranium were nigh enough for natural criticality. It is likely that other natural fission reactors existed in pre- or near-post ok lo time of about 2 oillion years before present. As earth history propossed beyond ok to time, the probability of natural fission decreased to essential impossibility due to the decay of the fissile nuclide $U-235$.

About 10 tons of fission products and 4 tons of Pu were produced over the period of criticality of about 100,000 years by 9 identified reactors (Gancarz et al., 1980). Temperatures during reaction reacned at least $600^{\circ} \mathrm{C}$ (probady $650-700^{\circ} \mathrm{C}$ ) within the reaction zone and were at least $400^{\circ} \mathrm{C}$ several meters outs ide the reaction zone (Vidale, 1978).

Oklo is a hybrid analog consisting first of a near-surface "ore" deposit with approximate conditions $25^{\circ} \mathrm{C}, 1$ atm., En $=-0.05$ to 0.45 and $\mathrm{pH} 7$ to 8.5 (Brookins, 1978). Second, the critical phase would follow closely the deposition phase presumatily under similar approximate geologic and geochemical conditions. If criticality continued for about $10^{5}$ years there would be an interesting coincidence with a third phase, snort to moderate term fission product benavior. The model value at this phase, though not idntical to modern waste isolation, is pernaps enhanced by the continuing presence of 
reaction heat which would approximate heat levels present in coucentrated waste.

A fourtn pinase of the Okio hybrid provides a look at long to very long $\mathrm{t}$ ime Dehavior $\left(10^{6}\right.$ to $10^{9}$ years) of the fission product mix, though during this phase as during later portions of the third phase, geologic and geochemical conditions may have varied consideraoly from the original apparently documentable conditions.

Conditions of actual waste isolation may also vary both in original (relative to $0 \mathrm{klo}$ ) as well as in the post-nistorical geologic environments of moderate term. Therefore, the evidence for stability drawn from ok lo must diminisn in statistical validity as the time factor relating it to waste increases. (Only one set of possible natural conditions prevailed at $0 k 10$ compared to many possible sets of conditions in actual isolation sites). However, long and very long times as generalized here can be eliminated from logical concern. Following the reasoning of Bredehoeft et al. (1978), times of more than $10^{5}$ years could be dropped from predictive/engineering concern relative to waste isolation installations.

Other natural fission sites need to be found and studied to improve the model but it is apparent that the very long term stabilities illustrated in tne study of uklo are extremaly important in verifying the conservatism of geo logic modeling.

Also note that in the study of actual observed element distribution at Oklo, En-pH diagrams of thenretical behavior of geotoxic species do not always apply and certain theoretically expected relationships are not observed (Brookins, 1978; Duffy, 1978). 
Studies of the $0 k$ io deposit suggest: (1) Retention of the rare earths and actinides, probably in the host piucholende; (2) Perhaps only local migration of the alkali and alkaline earths. These two statements essentially surnmarize the prime, significance of the model developed by studies to date.

The use of the 0klo reactor as an analog to waste disposal sites assunes that the radioactive wastes are in reduced form and are for the nost part incorporated into a stable minerai structure (i.e., uraninite in the $0 k 10$ case). Retention of the lanthanides and actinides at the 0klo site is primarily due to the stability of uraninite, in which they are contained.

Less than $10 \%$ of the fission products $R b$ and $S r$ were retained. Some migration of Tc and Ru was noted along with significant migration of $\mathrm{Kr}$, Ke, Ro, Cs, Sr, Ba, Mo, and I. Heavy elements remained relatively fixed, conclude Walton and Cowan (1973).

Otherwise modile or potentially mbile fission products must first escape from the uraninite $\left(\mathrm{UO}_{2}\right)$ grains by fission recoil $(5-10 \%)$ and volume diffusion (very slow). "The principal geochemical requirements for a suitable storage site are those that ensure the survival of tne $\mathrm{UO}_{2}$ matrix, particularly that the Eh and $\mathrm{pH}$ are similar to the values of Oklo" (Cowan, 1978). So, the stability of uraninite relative to Eh and $\mathrm{pH}$ is important not only in the possible distribution of uranium and chemically (mineralogically) associated elements, but of physically retained elements as well.

During the long post-reaction time (approximately $2 \times 10^{9}$ billion years) of $0 k$ lo history much Po has been lost to local migration following Jiffusion out of uraninite. Lead loss averaged about 50\% over this time period. "Local migration" here means movenneint of 3 to 5 meters with redeposition delow the reactor zone. 
$\mathrm{PlO}_{2}$ shows remarkadle stability under $0 \mathrm{k}$ lo conditions. $\mathrm{PuO}_{2}\left(\mathrm{CO}_{3}\right)_{2}^{-2}$ and $\mathrm{PuO}_{2}\left(\mathrm{CO}_{3}\right) \mathrm{OH}^{-}$fall within the stadility field of water at high En (over wide $\mathrm{pH}$ range). So carbonate comple:es may be important in nigh $\mathrm{CO}_{2}$ environments. The ionic radii of $\mathrm{Pu}^{4+}$ and $\mathrm{U}^{4+}$ are nearly identical and an almost ideal solid solution exists between $\mathrm{PuO}_{2}$ and $\mathrm{UO}_{2}$ at high temperatures. $\mathrm{Pu}^{4+}$ remains unoxidized as some $U^{4+}$ becomes oxidized to $v^{6+}$ in pitenblende (Brookins, 1978).

Note that in the above discussions and in the literature words such as "significant movement" or "out of the reaction zone" may refer to actual distances of a few meters or a few tens of meters.

B. Uranium Ore Deposits - Introduction:

study of the uranium ore deposits contributes to analog modeling of waste behavior in three genetic categories:

1. Pre-ore conditions contributing to mobilization of ore-associated elements.

2. Ore-localization and concentration conditions pointing to very specific immobilization.

3. Post-ore conditions that nave allowed stability of the ore masses for times upwurds of $10^{9}$ years $\left(10^{6}\right.$ year scale for Colorado Plateau-Type), or that may have remobilized or dispersed the ore concentrations.

recali tnat "ore" is an economic term referring to high concentrations of valuable materials. This implies concentrations of uranium and associated elements in which the uranium exists as several hundredths of a percent to several percent of the present rock. Of all known radioactive ore bodies only Ok to has been proven to have fissioned, therefore study of uranium ore 
deposits gives us information on the behavior of uranium and its decay products (not fission products) and any otner elements concentrated along witn the uranium in the ore-forming/retaining processes.

Associated elements very generally may include sny of the heavy, or precious metals as in the multi-element ore locales known as porphyry-copper deposits. Porpnyry-coppers may contain economically significant amounts of uranium. The uranium ore deposits proper have limited association with other elements such that only vanadium is routinely dealt with in genetic or economic studies of the deposits. As for decay products, experiments indicate that uranium is the "most mobile non-gaseous element in the uranium decay series within the surficial environment" (Oyck, 1y78). This parallels our general assumption that uranium mobility exceeds that for most of its associates, whether decay or fission products, in the near-surface and the humanly obtainable sub-surface environments.

Figures 1 through 6 show the general geochemical conditions of uranium ore deposition and elucidate the use of Eh-pH diagrams.

1. Uranium Ore Deposit Types

Uranium ore deposition as dealt with herein is predominantly classifiable into two categories:

a. Hyd"othermal ores (vein-types, "hardrock", replacement, etc.)

b. Colorado Plateau-type ores (sedimentary, "softrock", Grants-type, roll-type, etc.)

"Hydrothermal" implies hot-solution origin, generally associaced with a iocal heat source (and possibly an ore-element source) such as a molten rock mass. Other less localized or intense heat saurces are possible (Barnes, 1979), so 


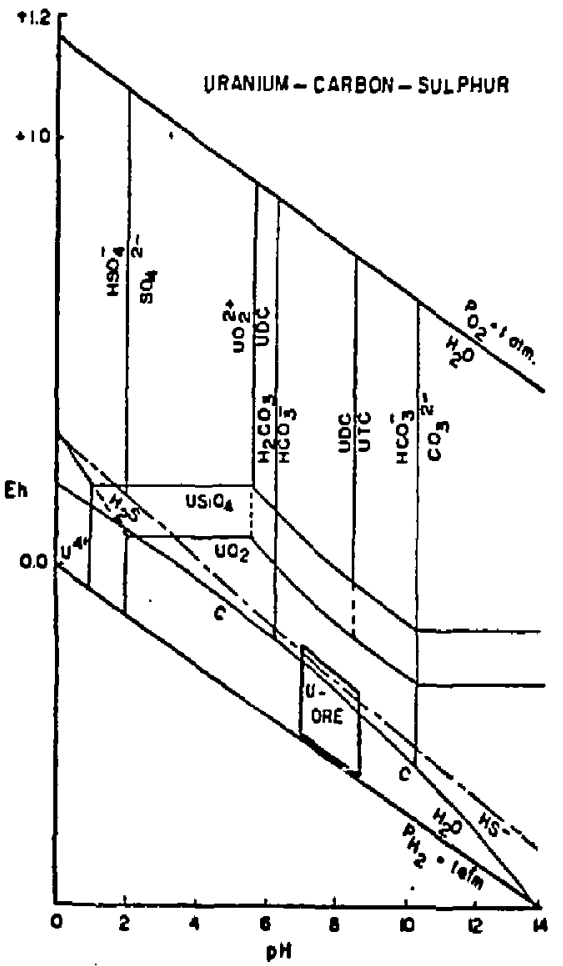

FIG, 1. Eh-pH diagram for part of this system U-S-Si-O-H-Fe. Assumed activities: $U=10^{-6}, \mathrm{Fe}=10^{-6}, \mathrm{~S}=10^{-3}$. (from I.A.E.A., 1978) 


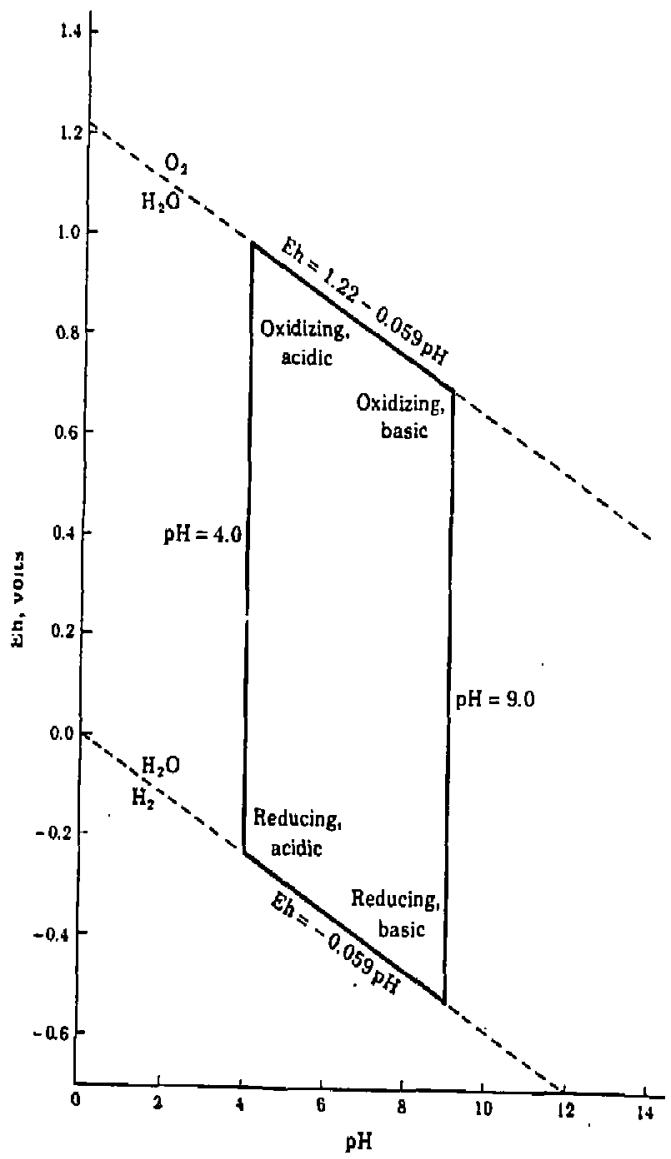

FIG. 2. Framework of Eh-pH diagrams. The parallelogram outl ines the usual 1 imits of Eh and $\mathrm{pH}$ found in near-surface environments. (from Krauskopf, 1967) 


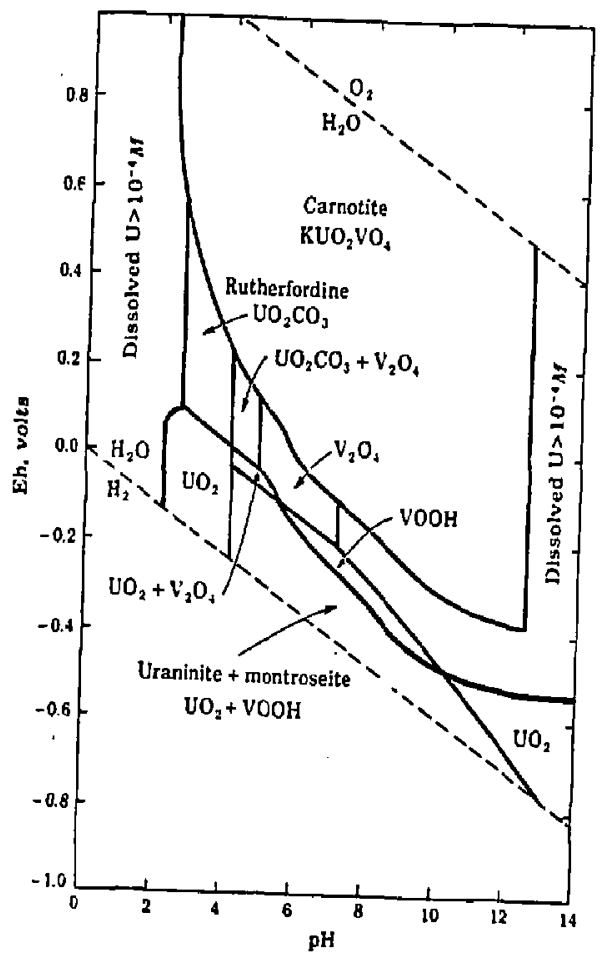

FIG. 3. Eh-pH diagram for uranium and vanadium compounds at $25^{\circ} \mathrm{C}$ and 1 atm total pressure. Total dissolved $Y=10-3 \mathrm{M}$, carbonate $=10^{-1} \mathrm{M}$. (from Krauskopf, 1967) 


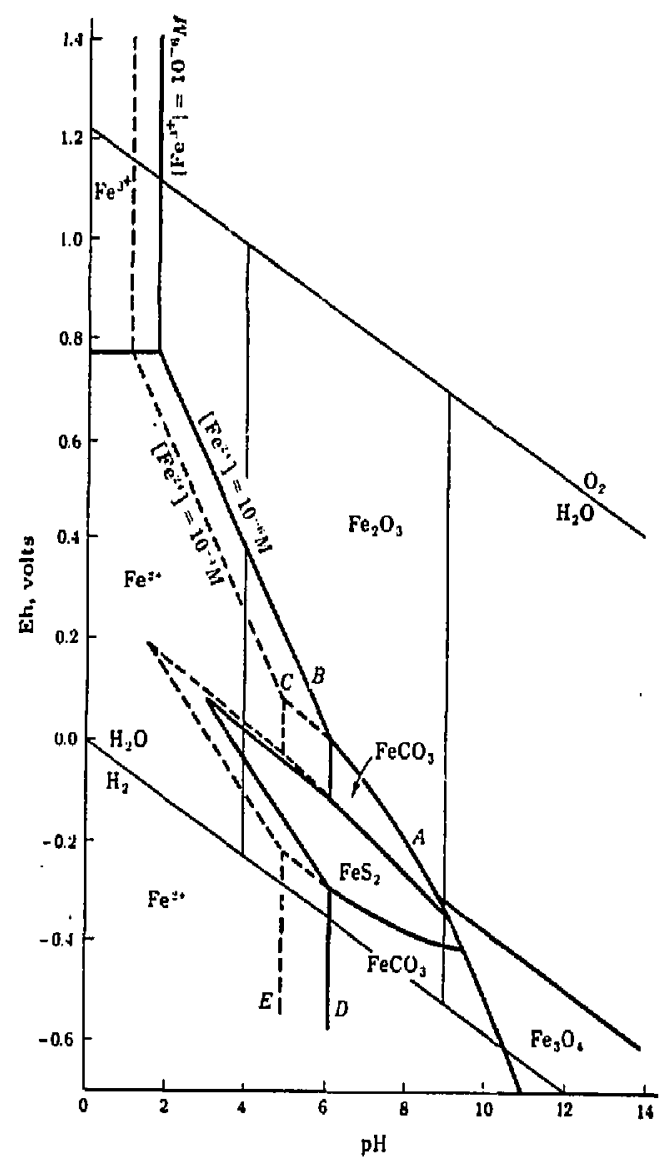

FIG. 4. Eh-pH diagrams showing stability fields of common iron minerals. Total activity of dissolved carbonate, IM, of dissolved sulfur, 10-6M. Solid field boundaries on left side of diagram are for total dissolved iron $=10^{-6 \mathrm{M}}$, dashed lines for 10-4M. (from Krauskopf, 1967)

$\mathrm{Fe}_{2} \mathrm{O}_{3}=$ Hematite; $\mathrm{FeCO}_{3}=$ Sidarite; $\mathrm{FeS}_{2}=$ Pyrite;

$\mathrm{Fe}_{3} \mathrm{O}_{4}=$ Magnetite. 


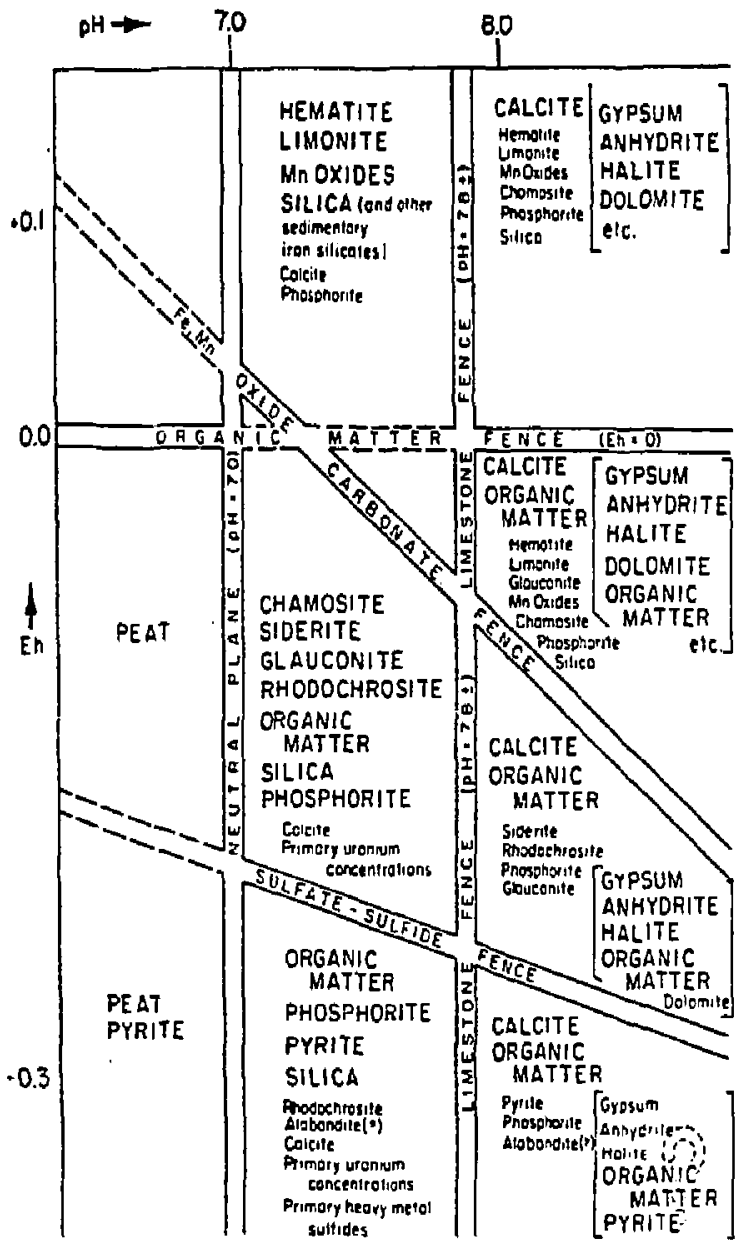

FIG. 5. Fence diagram showing En-pH fields in which chemical end-members of nonclastic sediments are formed under normal sea-water conditions. Associations in brackets are for hypersaline conditions (salinity $>200 \%$ (in Park and McDiarmid, 1964). 
DRANIUM

Becquerelite, $1 \mathrm{O}_{3}, 2 \mathrm{H}_{2} \mathrm{O}$.

Inthitite, $2\left(10.71 l_{-}\right)$

Rutheriosdine, $\mathrm{LO}$. $\mathrm{CO}$.

Urenatballite, $2 \mathrm{CaCO}$, t: $\left(\mathrm{CO}_{3}\right) .10 \mathrm{H}, 0$.

Vozlite, llydrous U, $\mathrm{C}, \mathrm{Cu}$, curbonate.

Mackinumhite, Ut, Th, Ce, silicate.

Tborogummite, Silingte of V,Th,Ce

Uranophune, $\mathrm{C}_{n} \mathrm{O} .2 \mathrm{~T}^{\mathrm{O}} \mathrm{O}, \mathrm{S} \mathrm{SiO}$.7H.O.

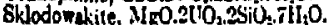

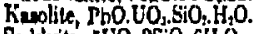

Sodd yite, sUO, $2510.6 \mathrm{H}, 0$.

Delorensite, Fe, U.Y, titauste.

Brannerite, (UOO,Tio, 110.)TiO

Biatchetiolite, U, Lunlalo-niobate.

Iobikannite UI niobate.

Samirbite, $U$ ete. niobate.

Fergusonite, $\Psi, E, U, U$, nobote.

Swmerakite, $\mathrm{Fe}, \mathrm{C}_{2}, \mathrm{U}, \mathrm{C}_{2}, \mathrm{Y}$, niobale.

Ampaneabute, $\mathrm{U}$, ete, piobale.
Eurenite

Polycrase tiknates.

Blomstrindine-Priorite

Betafice, If, niobste-titanate.

Pisckjte, U,Ce, etc., niobate and titunate.

Mendelyetrite, $\mathrm{Ca}, \mathrm{V}$, viohate and titarate.

Plumboniobite, $Y, U, P b$, niubrte.

Torbernite, Culliol, P. D. sllot

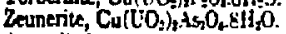

Autunite $\mathrm{Cs}_{(\mathrm{UO}) \mathrm{P}} \mathrm{P}_{\mathrm{S}} \mathrm{O}-8 \mathrm{H} \mathrm{O}$.

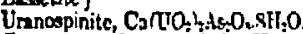

Dranocircite, Baflio, $\mathrm{P}_{5} \mathrm{O}_{2} .5 \mathrm{H}, \mathrm{O}$

Uranospathite, Hydrous urusyl phosphate.

Carsotne, li, $0.2(i, 0,1.0,3 \mathrm{H}$, ().

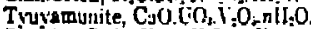

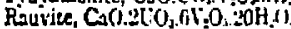

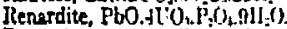

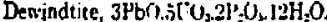

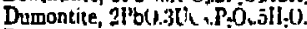

Parsonsite, $2 \mathrm{PbO}$. (OO. $\mathrm{Y}, \mathrm{O}, \mathrm{LI}, \mathrm{i})$.

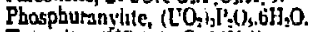

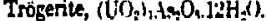

Uvasice, 2U0, $31: 0,151 \mathrm{H} 0$.

Ferehanite, $U_{3}(10,)_{1}, 6 \mathrm{H}_{1}(\mathrm{O})$.

Whalpurgite, $\mathrm{Bi}_{1,} \mathrm{UOO}_{3},(\mathrm{OH})_{33}(-150)$ t

UnNowre, Urany] efr., uranate.

Charkeite, $\left(\mathrm{Na}_{3}, \mathrm{~Pb}, 0.3 \mathrm{CO}_{\mathrm{O}} .3 \mathrm{H}, \mathrm{O}\right.$.

Gummite, alteration of umnitite.

Thorienite, Th and U oxides

Curite, 2P bO. 5 (In, $91 \mathrm{H}_{2} 0$.

Fourmaricrite, Hydroua Pb urinite.

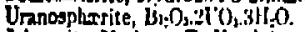

Johannite, Hydrous Cu, li sulpiate

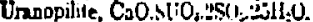

Zippeile, Hydrows Q sulphare.

FIG. 6. Uranium Minerals (from Dana, 1966). 
great variation in genetic conditions and final form are also possiole, but "hydrotnermal" possibilities range to the deeper, hotter, more chemically active end of the depositional spectrum which may be stretched to include "metamorphic" ores.

Colorado Plateau-types imply a more limited range of conditions, generally as in the near-surface environment. Circulating ground water and a broad source of uranium and its ore associates are the generalized genetic agents. Elevated temperatures are often postulated, as is a hydrotnermal source for ore-elements, so that a hydrotherma i categorization may be at least occasionally proper nere also. A family distinction is desirable, and particularly for our purposes, the Colorado Plateau-type, which dominates U.S. uranium production and information in American scientific literature, more closely resembles some proposed waste environments. The nydrotnermal model is covenient relative to possible aigh local heat and reactive brines likely to occur from presently favored disposal methods and environments.

\section{Summary of Uranium Depos it Chemistry}

This section summarizes the prime points affecting uranium mobility and immobility in all three genetic categories noted above.

Conclusions of this summary, and of Tables 6 and 7, may be previewed and abbreviated as follows. In the sense of minimizing the mobility of uranium:

a. Maintain a moderately reducing environment (as expected in most groundwaters in most rock types). This appears to be the overriding variable in uranium inmobility.

b. Keep tine $\mathrm{pH}$ range between ô to 8 (normal surface and near-surface environments). 
c. Minimize $\mathrm{CO}_{2}$ pressure whicn minimizes dissolved carbonate as readily attainable in arid and semi-arid environments.

d. Minimize halide crincentration in associated ...icers. (Note the implication here relative to salt disposal).

Natural or man-made buffer zones of iron, manganese, titanium, and especially carbonaceous matter would maximize sorption and buffer potentially serious changes in Fh. Though sorption processes may be valuade as delay or concentration limiting factors rlative to migrating toxins, these processes are highly variable, poorly understood and apparently by-passed in many natural mobile systems.

3. Uranium Deposition and Mobi ty; Reducing Environment

a. The extreme insolubility of uraninite and coffinite at normal ground water pH's (4-8) makes urinium practically immobile in low En environments regardless of otner moderate geologic and hydraulic variades (Langmuir, 1978).

D. Uraninite solubility increases at elevated $\mathrm{CO}_{2}$ pressures (in high alkalinity waters) due to dissociation of $\mathrm{CaCO}_{3}$. At high $\mathrm{pH}$, $\mathrm{CO}_{3}=$ is the predominant dissociation species so uranyl carbonate complexes form.

c. uranous fluorides are impurtant (stable and soluole complexes) at typical fluoride concentrations in reducing ground waters below $\mathrm{pH}=4$. They greatly enhance uranium solubility at low $\mathrm{pH}$ values. (Note: chloride complexes may have a similar out less profound effect.)

Overall, uranium is immobile in reducing environments unless relatively unusual conditions prevail as noted above. A change from reducing to 
oxidizing conditions (near-surface to surface environments) may instigate drastic increases in uranium mobility, although uranium still may not be extremely mobile even in the surface environinent unless certain conditions prevail.

4. Uranium Deposition and Mobility; Oxidizing Environment

a. Uranium transport generally occurs in oxidizing surface and ground waters as uranyl species, illost often as $\mathrm{U0}_{2}^{2+}$ or uranyl fluoride-, chloride-, phosphate-, carbonate- or sulfate-complexes. Highly oxidizing fluids, ill a $\mathrm{CO}_{2}$ environment, are those most likely to favor uranium transport over large distances.

b. At intermediate Eh's, oxidation and leaching of uraninite and coffinite are greatly enhanced (by several orders of magnitude) when phosphate and/or carbonate are present to form their highly stable uranyl complexes. Uranyl minerals are most stable in $\mathrm{pH}$ range 5 to 8.5 (Lanģmuir, 1978).

c. In unusually acidic near-surface environments (temperature under $100^{\circ} \mathrm{C}$ and $\mathrm{pH}$ values from 0 to 3) uranium sulfate and fluoride complexes are inportant soluble species. At common ground water concentrations of sulfate $(100 \mathrm{ppm})$, uranium sulfates may be a significant modile species up to $\mathrm{pH}=7$.

d. Hot brines, which are of an acidic oxidized nature, are considered carrier solutions for uranium mineralization.

e. Soil bacteria and microflora have been noted to increase uranium solubility, probably due to biosynthesis of complexing and chelating compounds. In general, the role of organisms in transport and 
precipitation or uranium is poorly understood. The role may be more important in fixation of uranium rather than transport.

f. Under conditions of low carbonate concentration, phosphate complexes are importanl soluble species. With ths $\mathrm{pH}$ range of ground waters in the Wind Rivers Formation, Wyoming ( $\mathrm{pH}=6.6$ to 8.3 ) Doth uranyl phospnate and carbonate complexes are abundant.

g. In the absence of vanadium and at atmospheric $\mathrm{CO}_{2}$ pressure the most cominon oxidized uranyl minerals are the autunites (Fig. 6) indicating a major role of phosphate (Langmuir, 1978).

$h$. With uranium in an oxidized environment at low to moderate $\mathrm{pH}$ values, carnotite is most likely to form. Tyuymunite is several times more soluble than carnotite but like carnotite it has a very low minimum solubility near $1 \mathrm{ppb}[U]$ at about $\mathrm{pH}=7$ (Langmuir, 1978). In other words, vanadium decreases the mobility of uranium even in moderately alkaline oxidizing environments.

i. If vanadium and phosphate concentrations are low, but silica is nigh the mineral uranophane will form and demobilize uranium. This is not a typical ground water condition, however (Langmuir, 1978).

j. Generally, even the soluble uranyl minerals are least soluble at pH's witnin the range 5 to 8.5 . Above $\mathrm{pH}=8.5$, uranyl carbonate complexes form; below $\mathrm{pH}=5, \mathrm{NO}_{2}^{2+}$ and other soluble cations form.

$k$. The $\mathrm{pH}$ range (5 to 8.5 ) of minimum soludility of the uranyl minerals is also the $\mathrm{pH}$ range of maximal sorption on most important natural colloidal materials. In the context of an oxidizing environinent, sorption (not solubility) controls total uranium in water up to mineral saturation, therefore sorption can be irmportant at low uranium concentration. 
1. Sorption experiments for clays, phosphates, and iron and titanium hydroxides in the $\mathrm{pH}$ range of 5 to 8.5 and in the absence of strong uranyl sulfate, fluoride and carbonate complexes which inhibit sorption, suggest that clays are relatively unimportant soroers.

m. Titanium and iron oxyhydroxides are the most important sorption media. There is good evidence that uranyl sorption is an important preconcentrating step leading to the formation of both uranyl and uranous minerals even though sorption effects over-all are umpredictable and not functional in open (hignly mobile) solution systems.

n. Reductants such as, humic acids, pyrite, hydrogen sulfide, carbon, solids, liquids or gases, and petroleum can cause uranium precipitation across very abrupt spatial changes from oxidizing to reducing environment. Especially clay rich traps, with abundant organic matter, establish the redox fronts along which near-surface uranium is deposited. These deposits may be destroyed or moved by continued flows of oxidizing waters, "although presently recognized redox front(s) may have been essentially stationary since early Tertiary" (Brookins, 1980).

0. Uranyl dicaroonate may coexist with pyrite under certain conditions but no uranyl species cre thermodynamically stable in the presence of carbonaceous matter (Kimberly, 1973). 


\section{SELECTED ELEMENT GEOCHEMISTRY, MATRIX PARAMETERS}

This section discusses the relationship, as drawn from the literature, between groups of selected elements and the geochemical functions presented in the matrices.

\section{A. Actinide Geochemistr:}

Tne general geochemical conditions that minimize uranium modility would also minimize the mobility of other actinides. These conditions are cnuracterized by:

1. reducing environments $\left(\mathrm{Fe}^{+2}\right.$ in biotite and/or pyrite, also organic matter);

2. $\mathrm{pH}$ in the range of 6.5 to 8.5 ;

3. Small to moderate bicarbonate/carbonate ion concentration; and

4. low dissolved salt content.

Figures 7 through 16 illustrate the type of data that form the basis of $m$-factor assignments relative to behavior of actinides in solution environments.

Self-oxidation/reduction cycles due to $\alpha$-radiation induced radiolys is in an aqueous environment could ennance mobility of the actinides, especially Am and Pu.

Actinides form an extensive series of complexes with halogens and, oxo-anions, such as $\mathrm{NO}_{3}^{-}, \mathrm{SO}_{4}^{2-}, \mathrm{Ox}^{2-}, \mathrm{CO}_{3}^{2-}$ and $\mathrm{PO}_{4}^{2-}$. The general tendency to complex formation is influenced by ionic size and charge such that:

$$
\begin{aligned}
& \mathrm{M}^{4+}>\mathrm{MO}_{2}^{2+}>\mathrm{M}^{3+}>\mathrm{MO}_{2}^{+} \text {and, } \\
& \mathrm{CO}_{3}^{2-}>\mathrm{Ox}^{2-}>\mathrm{SO}_{4}^{2-} \text { (Cotton and Wilkinson, 1y67). }
\end{aligned}
$$




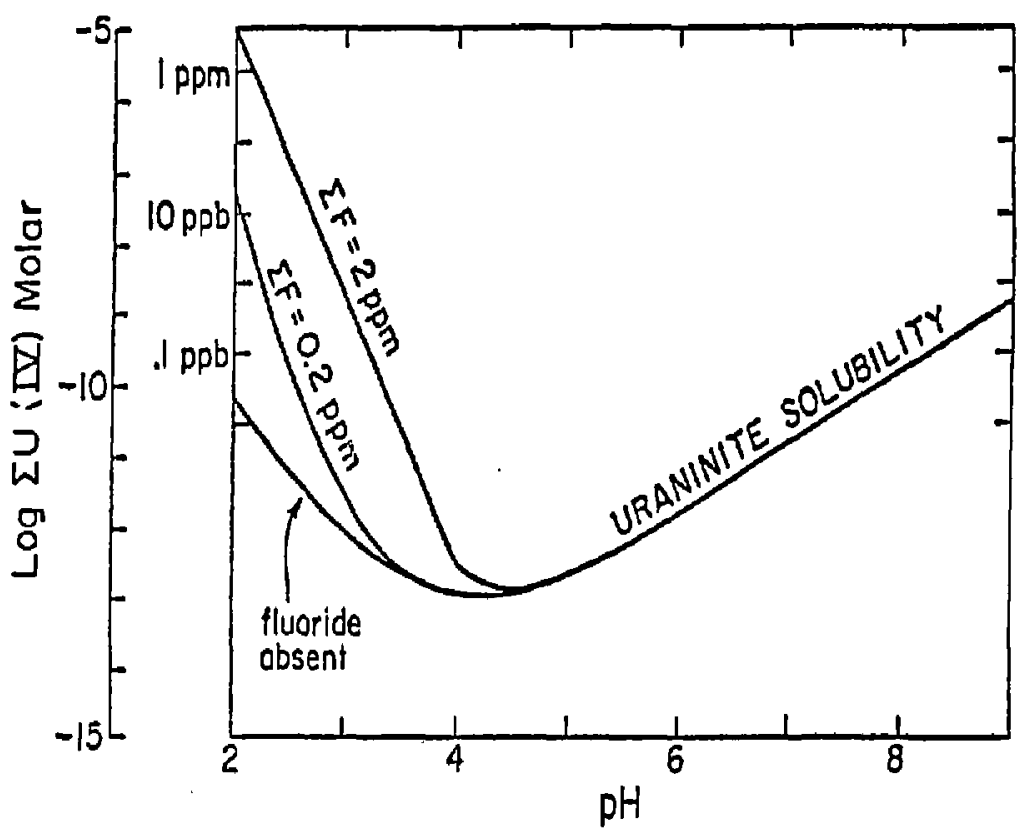

FIG. 7. The effect of uranous-fluoride complexing on the solubility of uraninite $\mathrm{UO}_{2}(\mathrm{C})$, versus $\mathrm{pH}$ at $25^{\circ} \mathrm{C}$. (from Langmuir, 1978). 


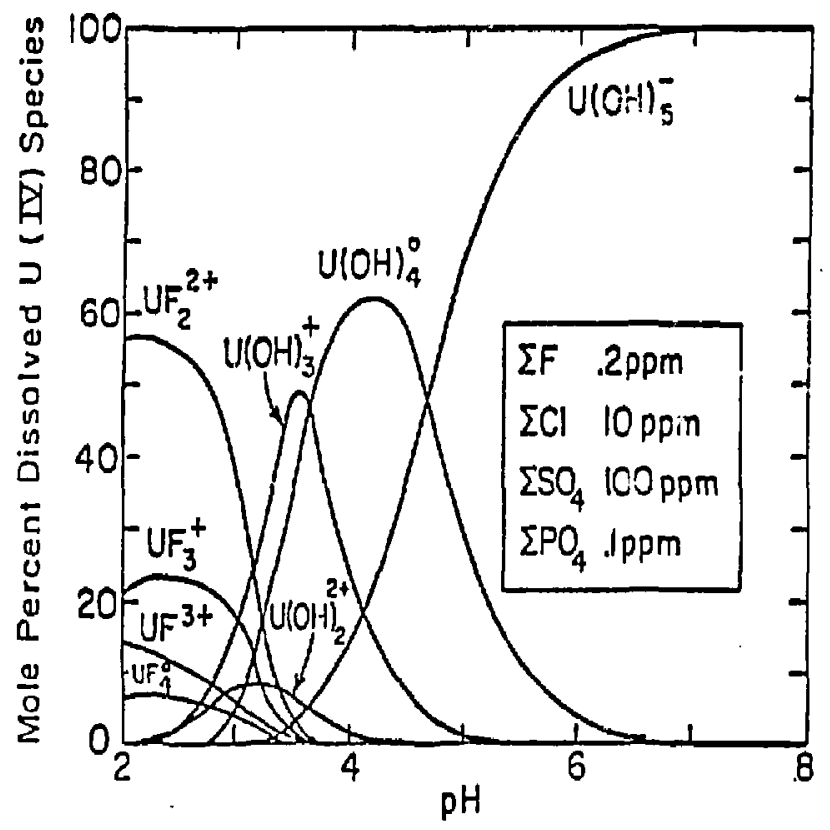

FIG. 8. Distribution of uranous complexes versus $\mathrm{pH}$ for some typical ligand concentration in ground water at $25^{\circ} \mathrm{C}$ (from Langmuir, 1978). 


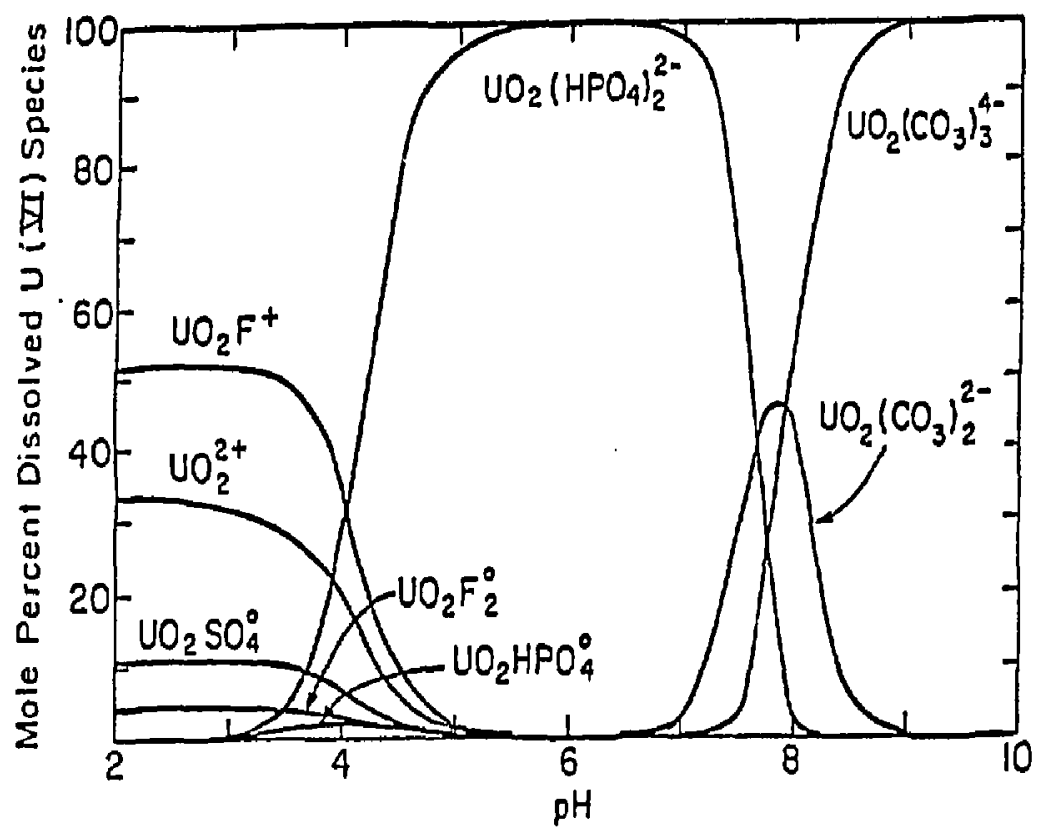

F16. 9. Distribution of uranyl complexes versus $\mathrm{pH}$ for some typical ligand concentrations in ground waters of the Wind River Formation at $25^{\circ} \mathrm{C} . \mathrm{PCU}_{2}=$ $10^{-2.5} \mathrm{~atm}, \Sigma \mathrm{F}=0.3 \mathrm{ppm}, \Sigma \mathrm{Cl}=10 \mathrm{ppm}, \Sigma \mathrm{SO}_{4}=100 \mathrm{ppm}, \Sigma \mathrm{PO}_{4}=0.1 \mathrm{ppm}$, $\mathrm{LSiO}_{2}=30 \mathrm{ppm}$ (from Langmuir, 1978). 


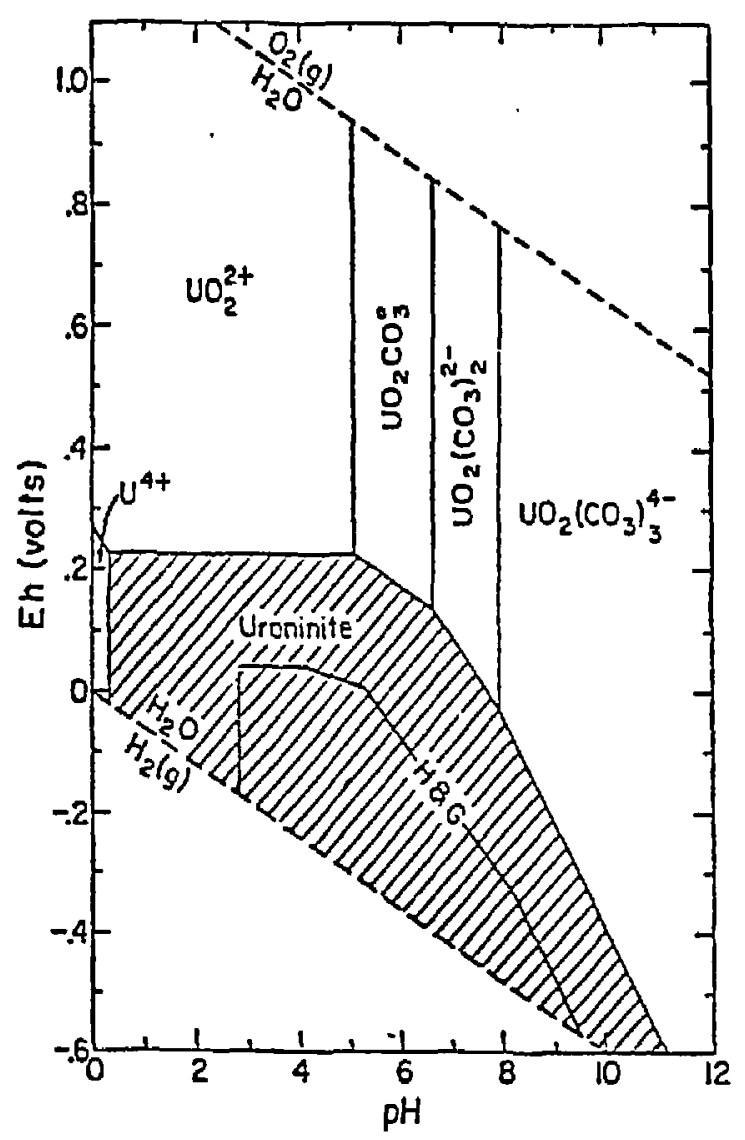

FIG. 10. Eh-pH diagram in the $\mathrm{U}-\mathrm{O}_{2}-\mathrm{CO}_{2}-\mathrm{H}_{2} \mathrm{O}$ system at $25^{\circ} \mathrm{C}$ for $P_{\mathrm{CO}_{2}}=10^{-2} \mathrm{~atm}$. Uraninite, $\mathrm{UO}_{2}(\mathrm{c})$, solution boundaries are drawn at $10^{-6} \mathrm{M}$ $(0.24$ ppin) dissolved uranium species. "H \& G" denotes the boundary of the uraninite stability field according to Hostetier and Garrels (1962) (in Langmuir, 1978). 


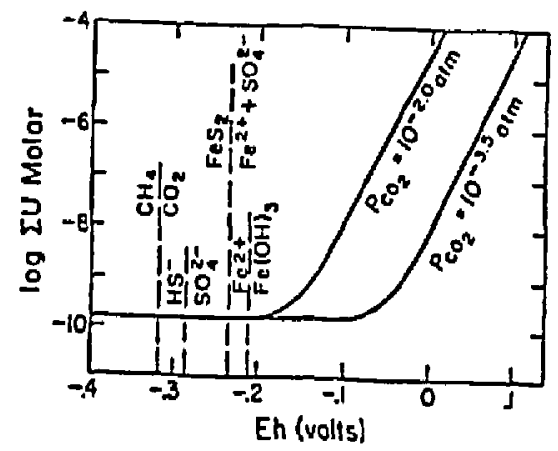

FIG. 11. The solubility of uraninite, $\mathrm{UO}_{2}(\mathrm{c})$ at $\mathrm{pH}=8$ and $25^{\circ} \mathrm{C}$ as a function of Eh and $\mathrm{P}_{\mathrm{CU}_{2}}$. Also shown are the Eh values for some important redox reactions computed assuming:

$$
\begin{aligned}
& \mathrm{CH}_{4}=\mathrm{CO}_{2}, \mathrm{SO}_{4}^{2-}=\mathrm{HS}^{-}, \mathrm{Fe}^{2+}=10^{-4} \mathrm{M} \text {, and } \\
& \mathrm{SO}_{4}^{2-}=10^{-3} \mathrm{M} \quad \text { (From Langmuir, 1978). }
\end{aligned}
$$

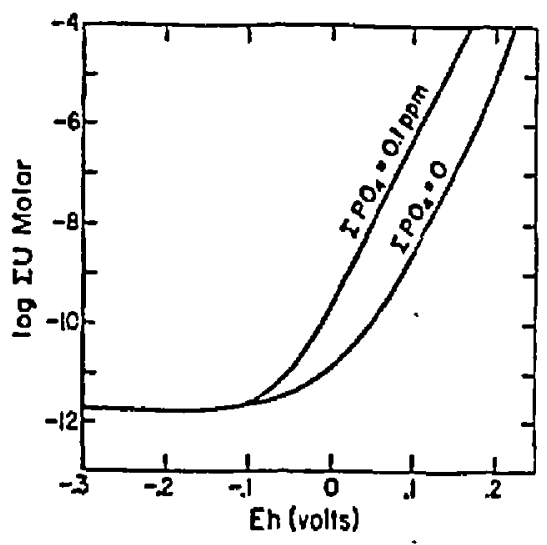

FIG, 12. The solubility of uraninite, $\mathrm{UO}_{2}(\mathrm{c})$, at $\mathrm{pH}=6$ and $25^{\circ} \mathrm{C}$ as a function of $\mathrm{Eh}$ for $\mathrm{PCO}_{2}=10^{2.0} \mathrm{~atm}$, with $\mathrm{PO}_{4}$ absent, and for $\Sigma \mathrm{PO}_{4}=10^{-6} \mathrm{M},(0.1 \mathrm{ppm}) \quad$ (From Langmuir, 1978). 


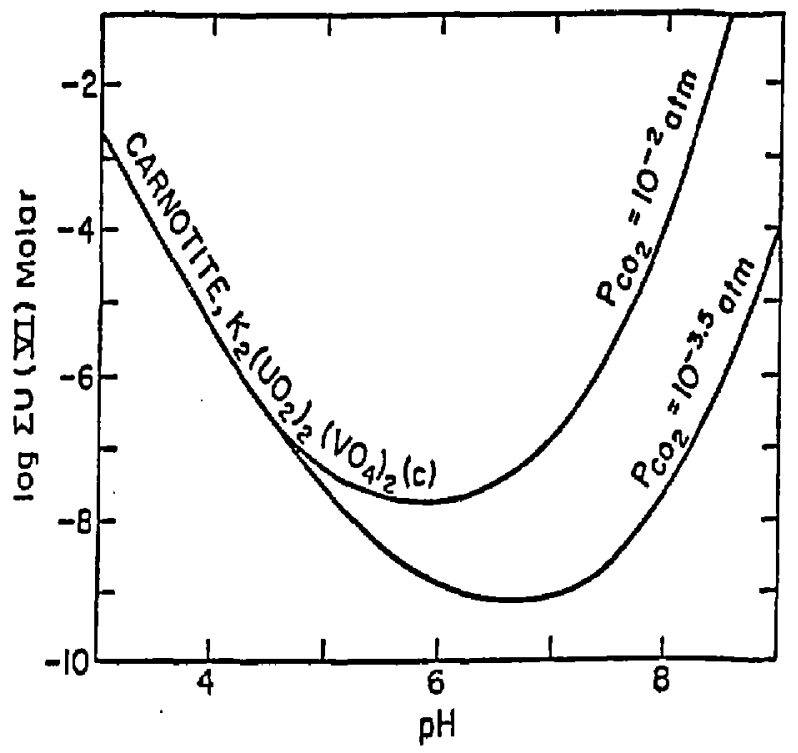

FI6. 13. Solubility of carnotite at $25^{\circ} \mathrm{C}$ as a function of $\mathrm{pH}$ and $\mathrm{P}_{\mathrm{CO}}$ for $K=10^{-3} \mathrm{M}(39 \mathrm{ppm})$ and $\Sigma V=10^{-6} \mathrm{~N}\left(0.1 \mathrm{ppm}\right.$ as $\left.V \mathrm{O}_{4}\right)$ (from Langmuir, 1978). 


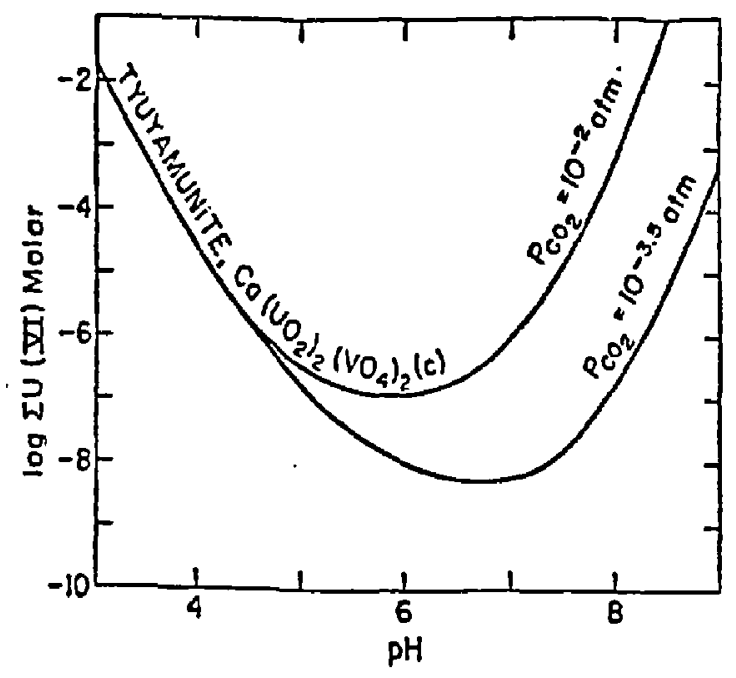

FIG. 14. Solubility of tyuyamunite at $25^{\circ} \mathrm{C}$ as a function of $\mathrm{pH}$ and $\mathrm{PCO}_{2}$ for $C a=10^{-2.7} M(80 \mathrm{ppm})$, and $\Sigma V=10^{-6} \mathrm{M}\left(0.1 \mathrm{ppm}\right.$ as $\left.V_{4}\right)$. (From Langmuir, 1978). 


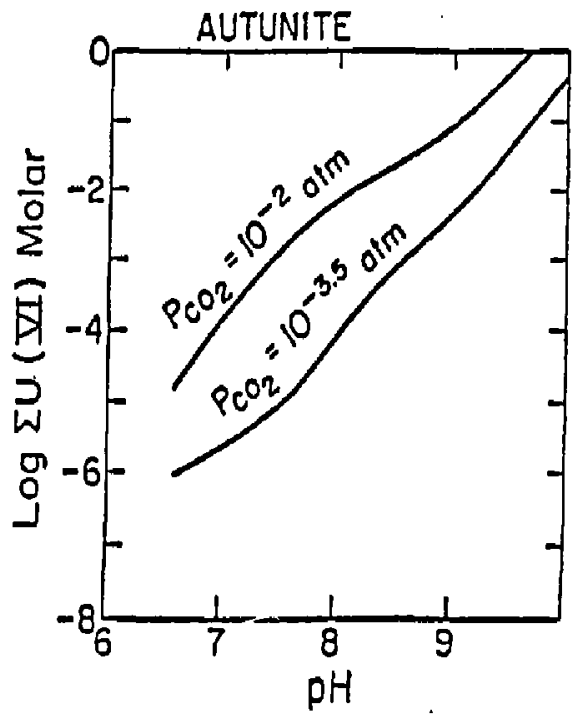

FIG. 15. Solubility of autunite at $25^{\circ} \mathrm{C}$ as a function of $\mathrm{ph}$ and $\mathrm{P}_{\mathrm{CO}_{2}}$ for $\mathrm{Ca}=10^{-2.7} \mathrm{M}(80 \mathrm{ppm})$, and $\sum \mathrm{PO}_{4}=10^{-6} \mathrm{M}(0.1 \mathrm{ppm})$.

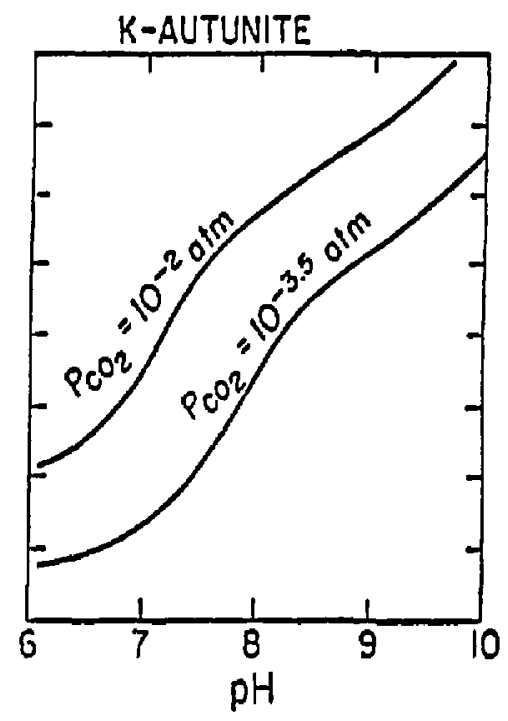

FIG. 16. Solubility of potassium autunite at $25^{\circ} \mathrm{C}$ as a function of $\mathrm{ph}$ and $\mathrm{P}_{\mathrm{CO}_{2}}$ for $\mathrm{K}=10^{-3} \mathrm{M}(39 \mathrm{ppm})$ and $\Sigma \mathrm{PO}_{4}=10^{-6} \mathrm{M}(0.1 \mathrm{ppm})$.

(Both figures from Larigmuir, 1978). 
Stapilities of the oxidation states are:

$\mathrm{UO}_{2}^{2+}>\mathrm{NpO}_{2}^{+}>\mathrm{PuO}_{2}^{2+}>\mathrm{AmO}_{2}^{2+} ; \quad \mathrm{Am}^{3+}>\mathrm{Pu}^{3+}>\mathrm{No}^{3+}$.

Complex formation can shift the oxidation potential and influence tne relative stabilities of oxidation states for actinides. The stability of the nigher oxidation state falls from uranium through americium.

"Under anoxic conditions to be expected in a deep underground repository in igneous rock, the actinides would be expected to exist predominately in the tri- and tetra-valent state. The aqueous chemistry in these valence states at environnental $\mathrm{pH}$ levels is largely dominated by nydrolys is reactians. In oxic systems like surface waters, the penta-and hexa-valent states would predominate (for $U, N p$ and possibly $\mathrm{Pu}$ ). For these higher valence states the aqueous cnemistry would be entirely different at environmental pH levels, with a much lower degree of hydrolysis and higher overall mobility, "Beall et al., $1980)$.

Therefore, mobility is not only a function of the benavior of stable states but also a function of the rates of conversion from other oxidation states.

Given the relative stabilities of the oxidation states and very similar chemical properties, geochenical environments which immobilize uranium would De expected to also immodilize Np, Pu, and An.

The tendency of actinides to hydrolyze is: $A m>P_{U}>N p>V$ and $\mathrm{M}^{4+}>\mathrm{HO}_{2}^{2+}>\mathrm{M}^{3+}>\mathrm{MO}_{2}^{+}$(Cotton and Wilkinson, 1967).

The inaximum concentration of tetravalent elements in solution is i imited Dy the precipitation of hydroxides, which like for uranium, might be transfixed into dioxides (Allard, 1979). 
Neptunium exists as $\mathrm{NpO}_{2}^{+}$in an aerated solution (Allard, 1979). The formation of sulfate complexes of $\mathrm{Np}^{4+}$ and $\mathrm{NpO}_{2}^{2+}$ is also noted (Cotton and dilkinson, 1967). This illustrates influence of complex forming anions on the oxidation state of $\mathrm{Np}$ and other oxides.

The aqueous chemistry of Pu (like $U, N p$ and Am) is complicated by the fact that all four oxidation states can coexist in appreciable concentration in a solution. Aqueous solutions of $\mathrm{Pu}$ and $\mathrm{Am}^{+4}$ and $\mathrm{Am}^{+6}$ undergo rapid self-reduction due to their a-radiation (Cotton and wikikinson, 1967).

The oxidation state of $P u$ in aqueous solutions is affected by radiolysis of the water: "Water radiolysis will be a major factor in determining the oxidation state of Pu solutions in the near vicinity of the radiation field of a waste repository. It can be postulated that even small quantities of $\mathrm{Pu}$ carried away from the repository by some leaching and transport process and subsequently adsorbed on some mineral in a rock will be subjected to the oxidation effects of radiolysis from its own alpha activity." The net result of a series of reactions initiated by rartiolys is of the water is that Pu may undergo a cycle of oxidation and reduction. The period of the cycle will depend on $\mathrm{Pu}$ concentration, radiation field intensity, $\mathrm{pH}$, temperature and formation of complexes; $\mathrm{Pu}^{+3}+\alpha$-radiation $+\mathrm{H}_{2} \mathrm{O}+\mathrm{Pu}^{4+}+\mathrm{P}_{u}{ }^{6+}$ (Fried et al., 1980). (Amu ${ }_{2}^{+}$is reduced [4\%/hour j by products from its own $\alpha$-radiation).

Two random examples fiom real world tests:

1. The mobility of Pu in natural soils was determined to be 0.2 to 2 cm/year (Jakubick, 1979).

2. Concentration factors of $P_{u}$ in aquatic plants and animals can De quite nigh, for example, $2 \times 10^{4} \mathrm{ppm}$ in North Atlantic sargassum; $10^{3}$ ppn in edible bivales; but less than 19 ppm in edible fish tested (NEA, 1977). 
Also note the following excerpt from Ogard et al. (1980):

"It has been suggested for the management of nuc lear waste that the reducing conditions that frequently occur in deep geologic burial woulc result in very slow leaching of spent-fuel elements in contact with water. We have conducted leaching experiments both in the oxidizing condition of air-saturated water and in reducing conditions produced by bubbi ing hydrogen or hydrogen-argon gas mixtures through the water. A reducing solution praduced in this manner proved not to be very reducing as evidenced by the high concentration of uranium found in the leachant. The concentration of uranium in the reducing water was only a factor of 10 less than in the air-saturated water whereas estimates of up to a factor of $10^{10}$ less were thought possible. These results do, however, provide other information of value to the management of nuclear waste.

We have compared the concentration of uranium, fission products and other radionuclides found in the leachant to their concentration in the spent-fuel element and nave concluded three tnings: 1) The radionuclides cerium, plutonium, americium, and europium reach a maximum concentration in the leachant and precipitate as further dissolution of the $\mathrm{UO}_{2}$ matrix takes place. 2) The precipitate appears to have a negative temperature coefficient of soluoility. 3) Congruent dissolution of the $\mathrm{UO}_{2}$ matrix is the primary mechanism for release of the radionuclides into the leachant under oxidizing and slightly reducing conditions."

The solubility limits in water of the rare-earths and actinides investigated in this system are listed in Table 9. 
TABLE 9. Ooserved Solubility Limits at pH4, Deionized water (From Ogard et ai., 1980)

\begin{tabular}{|c|c|c|c|}
\hline \multicolumn{4}{|c|}{ Moles/Liter } \\
\hline Element & $25^{\circ} \mathrm{C}$ & $70^{\circ} \mathrm{C}$ & Condition \\
\hline$\vec{E} u$ & $\geq 3 E-8$ & $2 E-9$ & $0 \& R$ \\
\hline $\mathrm{Ce}$ & $\geq 3 \mathrm{E}-7$ & $1 E-8$ & $0 \& R$ \\
\hline Am & $\geq 5 E-8$ & $2 k-9$ & $0 \& R$ \\
\hline $\mathrm{Pu}$ & $\geq 3 E-7$ & $1 E-8$ & $0 \& R$ \\
\hline \multirow[t]{2}{*}{$U$} & $>5 E-5$ & $>3 E-4$ & 0 \\
\hline & & $22 E-6$ & $R$ \\
\hline
\end{tabular}

$0=$ air-saturated water, $R=$ reducing conditions

$3 E-8=3 \times 10^{-8}$ moles/liter

B. Comparison of Actinide and Lanthanide Chemistry:

The actinide elements, especially $U$ through Ari, have analogous geochemical benavior. Also the lantnanide elements, have analogous geochemical behavior within their group. The actinides do net necessarily benave like the lanthanides. Althounn some similarities do exist, the aqueous chemistries of the groups are significantly different.

"Major characteristics of the distribution of rare elements (rare metals and rare eartins) in sedimentary rocks can be related to ionic size, charge and bond cnaracter. Sudstitution of rare-metals ions for major ions in crystal structures is of minor importance and adsorption of rare-metal jons on the surface of particles in fine-grained sediments plays a major role," (Krauskopf, 1907).

Since the outer electron structures are so similar, tine elements of the lanthanide and actinide series show very similar chemical properties within their respective series; so similar that they generally occur int imately associated in nature. The generalization is less true for the actinides than for the lanthanides, because some of the former have stade higher valences (additional electrons coming from the shell under the valence shell). 
Generally, the chemistry for all lanthanides and actinides in the $i^{3+}$ and $\mathrm{i}^{4+}$ states are similar, and the ionic radii for most of the actinides and the lanthanides are comparable within 15\%. This suggests similar potential for substitution in minerals, even though the charge may differ by one unit.

In the actinide series, the energies of the outer orbitals are about comparable over a range of atomic numbers, especially for uranjum through americium and since the orbitals overlap spacially, bonding can involve any or all of them. Actinides, therefore, have a cendency to form complexes and bond covalently. In contrast, lantnanides bond almost exclusively ionically and form virtually no complexes or covalent compounds.

\section{c. Lanthanide Geochemistry:}

Reducing conditions in geomedia would immobilize lantnanides (Brookins, 197y). A lamprophyre dike near the WIPP site can be considered as a natural analog for a high temperature canister emplaced in bedded evaporite, Data indicate retention of most if not all elements originally present in the dike despite 1 to 2 meter contact zone effects on the evaporite sequence. The dike is enriched in lanthanides (Brookins, 1980).

Apparently there is little exchange of the lanthanides with clay minerals due to interaction with brine. The slight depletion of light (La, Ce) rare earths and enricnmen: of heavy rare earths is due to tne formation of Mg-rich clay minerals such as chiorite-saponite, at the exposure of pre-existing smectites. The slight loss of La and Ce is due to incorporation of these elements into included salts or into oxide-hydroxide coatings (Register et al., 1980). 
Preferential fixation of lanthanum and cerium into calcareous sediments is due to control by similar ionic radii for $\mathrm{Ca}^{2+}$ (in the sediments), $\mathrm{La}^{3+}$ and $\mathrm{Ce}^{3+}$. Sea water shows a pronounced cerium depletion. It has been proposed that the depletion is due to formation of $\mathrm{Ce}^{4+}$ which is removed $D y$ precipitation with ferromanganese nodules (Register et al., 1980). (The section on Sorption presents additional information on lanthanide effects).

D. Hikali Metals (Rb and Cs) Geochemistry:

Monovalent elements like Cs would not form any complexes in ground water (Allard, 1979). "Rb/Sr dating of clay minerals penecontemporaneous with uranium mineralization indicates closed system conditions for $\mathrm{Rb}$ and $\mathrm{Sr}$ since the time of ore formation 135 to 140 million years ago. Because of the greater retentivity of $C S$ and $R b$ in most clays, an indirect argument can be made for these rocks being closed to is since time of formation as well," (Brookins, 1980). Host of the geochemical data on these elements deals with sorption effects. See the section on sorption for further discussions.

E. Alkaline Earths ( $C a, 5 r, B a, R a)$ Geochemistry:

Little discrimination between ${ }^{83} \mathrm{Sr}$ and ${ }^{45} \mathrm{Ca}$ in either precipitation or cation exchange was observed in soil, therefore $\mathrm{Sr}$ seems to behave like Ca in soils.

Maximum concentration of $\mathrm{Sr}$ (divalent) in ground water is limited by precipitation of non-soluble carbonate (Allard, 1979).

$\mathrm{Na}_{2} \mathrm{SO}_{4}$ has been proposed for use in waste canister overpacks to limit Sr mobility in orine environments. 
Generally, uranium appears to be more mobile than radium around uraniun deposits in Canada. Accumulations of radium are particularly prominent in ground waters which arise from sufficient depth, such that reducing conditions prevail. As $\mathrm{Fe}$ and Mn precipitate upon oxidation, radium becomes adsorbed on the oxides. Moreover, deep water usually contains large amounts of $\mathrm{CO}_{2}$ which escapes when the water reaches atmospheric pressure. This $\mathrm{CO}_{2}$ escape causes $\mathrm{Ca}$ - and Mg-carbonates to presipitate with the co-precipitation of Ra. This phenomena is particularly evident near mineral springs. Geochemical controls which depress Ra concentration in water are:

1. cation exchange with clays

2. co-precipitation with geochemically related elements, $\mathrm{Ca}$ and $\mathrm{Mg}$.

3. adsorption onto $\mathrm{Fe}$ and $\mathrm{Mn}$ hydrous oxides (Dyck, 1978).

Typical radium concentration in oxidized ground water is about $1.0 \times 10^{12} \mathrm{~g} / 1(0.1$ picograms/1). In brines the dissolved radium content increases ten to even several hundred picograms/l due to complexing with $\mathrm{Cl}^{-}$. Ra in water increases under reducing conditions around deposits not Decause of dissolution of Ra itself, but due to dissolution of Fe-iln hydroxides which removes a major host for Ra adsorption. So, radium increases with depth due to greater salinity of ground water and reducing conditions wnich dissolve Fe-Mn oxides (Dyck, 1978). This maximum concentration of Ra in ground water is limited by precipitation of a non-soluble sulfate (Allard, $1979)$.

Reconcentration and resulting enhanced radiation field of $T$ and $R a$ due to different migration rates of a parent/daughter chain is discussed by Burknolder and Cloninger (1978). 
F. Iodine:

Iodine environmental chemistry is a topic in itself. It certainly is soluble (as are the other halogens) and mobile in the geochemical environment in many ways. Further, sorption of iodine is generally low (See Sorption Section) and iodine may migrate in halite by diffusion (Brookins, 1979). Mooility is decreased in reducing environments.

The toxicity arguments for iodine (229) are interesting. On one hand is the nign geochemical mobility and the high biological (including human) affinity for the element. Counter to this is the extremely long half-life of $I^{229}$ (very low specific activity).

Iodine should be assumed to be nighly mobile geochemically. Barriers generally must be physical or time-distance related. The question of base toxicity must be settled by the toxicology/health physics community.

\section{G. Metals:}

Ruthenium (Ru) - Reducing conditions would increase retardation of Ru in a brine, possibly as a sulfide with some hydroxide (Brookins, 1979).

Humic acid promotes sorption of Ru. Nitrite ions strongl! complex $\mathrm{Ru}^{2+}$ to form neutral or anionic complexes which are very weakly sorbed by sediments and thus decrease the sorption of Ru (Barney, 1979).

Ru did snow a tendency to sorb on halite containing clay from brine simulant solution at $\mathrm{pH}=6.5-7.9$ (Dosch, 1979).

Antimony $(\mathrm{Sb})$ - Owing to similar ionic radius $\mathrm{Sb}^{3+}$ can substitute for Doth ilb and Ta and vice versa.

Nickel and Cobalt ( $\mathrm{Ni}$ and $\mathrm{Co}$ )- $\mathrm{Co}$ ano $\mathrm{Ni}$ are estimated to be about 20 times as abundant in uranium ores as in unmineralized sandstone. Nickel enrichment is more pronounced in the clay-sized fraction than in the whole-rock samples (Brook ins, 1980). 
Nitrite ions strongly complex $\mathrm{Co}^{2+}$ to form neutral or anionic complexes which are very weakly sorbed by sediments. Thus $\mathrm{NO}_{2}^{*}$ decreases sorption of Co. Humic acid inbibits sorption of Co apparently by forming soluble complexes with $\mathrm{Co}^{2+}$ (Barney, 1979).

Lead $(P D)$ - Lead is relatively immodile due to insoluble sulfides and sulfates (Dyck, 1978). "In the weathering zones (oxidizing), Pb-rich uranium minerals lose lead and are ultimately replaced by uranophane and montmorillonitic clay" (Rimsaite, 1978).

Diffusion loss of lead from nost uraninite appears to be an important process in the fractionation of lead from uranium, (Gancarz et al., 1980).

Other metals- For Eh-pH diagrams of Ru, Cd, In, SD, Ag, Pd, Zr, Rh, Re, Mo, Sn, Te, Bi, Y and Nb refer to Brookins (1978).

\section{H. Technetium:}

$\mathrm{Tc}^{4+}$ is sparingly soluble in reducing environinents. Reducing conditions would increase retardation of Tc in a brine or other geomedia, possioly by incorporation into carbonates or absorbed on clays (brookins, 1979). Also under reducing conditions $\mathrm{TCO}_{4}^{-}$may precipitate as an oxide. Augite adsorbs $\mathrm{TcO}_{4}^{-}$(bird and Lopata, 1980).

See Allard et al. (1979) and Brookins (1978) for En-pH diagrams for technetium, and also Section VI on Sorption. 


\section{GEOCHEMICAL PARAMETERS USED IN MATRIX}

This section examines effects in terms of the geochemical parameters (Eh, $\mathrm{pH}$, mineralogy, presence of anions, temperature) on the most significant group of elements, the actinides.

\section{A. Effects of Eh on Actinide Geocnemistry}

En (oxidation potential) is the single most important variable influencing the mobility of actinides in near surface environinents. Reducing conditions in the geomedia would immovilize the actinides (Brookins, 1979) Decause the reduced species form very insoluble oxides/hydroxides and sorption is greatly ennanced (Allard et al., 1979). Comparisons of actinide chemistry indicate that uranium is potentially the most mobile actinide and conditions leading to immobilization of uranium would also immobilize Np, $\mathrm{Pu}, \mathrm{Am}$ and $\mathrm{Th}$. Uranium chemistry proxies behavior of the group. The dominant mechanism speculated for uranium ore deposition (immobilization) is reduction notably by organic matter, ferrous iron compounds (minerals) and/or sulfur compounds (Allard, 1975; Rich et al., 1975; Barthel, 1974).

Under axidizing conditions uranium is generally one of the most mobile trace elements, mostly owing to the high stability of its complexes, especially tne carbonate complexes. The uranyl ion is mobile in natural and alkaline solutions if carbonate is present and somewhat mobile in weaxly acid solutions (due to sulfate, halogen and hydroxide complexes).

Carbon readily reduces uranium. However, under certain conditions, the uranyl ion may be stable in the presence of reduced iron and sulfur. The uranous ion is oxidized in the presence of oxygen, $\mathrm{MnO}_{2}$, and possibly hematite. 
Under mildly reducing conditions, complex formation and self-oxidation/ reduction due to $\alpha$-radiation-induced radiolysis may affect mobility.

\section{Effects of $\mathrm{pH}$ on Actinide Geochemistry}

The reduceo forms of $\mathrm{U}, \mathrm{Np}, \mathrm{Pu}$ and $\mathrm{Am}$ are insoluble at $\mathrm{pH}=6.5$ to 8.5. The important uranyl minerals (carnotite and autunite) are least soluble at $\mathrm{pH}$ of 5 to 8.5 (less than $1-2 \mathrm{ppb}$ of $U$ should be present in saturated ground water), jolubilities increase significantly for $\mathrm{pH}$ values below 5 and above $g$ for all species. Thorium is generally insoluble at normal environmental $\rho \mathrm{H}$ values, particularly for the pH range 7 to 8 . There is some evidence that uranium may form a mobile species $\mathrm{UO}_{3}^{+}$under slightly reducing conditions at pH below 7 .

At normal environmental pH values (6 to 8 ) carbonate and phosphate complexes contribute to the mobility of oxidized uranium. The effects of fluoride and sulfate are minimal with this pH range.

\section{Effects of Mineralogy on Actinide Geochemistry}

Mineral species influence the adsorption and oxidation/reduction potential of the rock and associated ground fluids. Adsorption is considered by some to de an inportant preconcentrating step for the ultimate immobilization of uranium by reduction to $\mathrm{UO}_{2}$. Others perceive reduction as a precursor for adsorption. Comnon rock-forming minerals which are important because of their reducing and/or adsorption properties include: zeolites, clays, iron-manganese-titanium oxyhydroxides, biotite, hornblende, pyrite/marcasite, fossil carbon, $\mathrm{CH}_{4}, \mathrm{H}_{2} \$$, petroleum, bitumens, grapnite, and humic acid. The presence of the above materials reduces the potential for 
actinide migration. The most effective agents for immobilization are carbon and hydrocaroon compounds.

Low temperature alteration of clay in association with cardonaceous matter and sulfides may be a significant mechanism for the precipitation of uraninite.

Manganese and iron oxides are potential sorbers. Also $\mathrm{MnO}_{2}$ and possioly hematite can convert reducing fluids into uranium carriers.

0. Effects of the Presence of Anions on Actinide Geochemistry

$$
\left(\mathrm{CO}_{3}^{*}, \mathrm{HPO}_{4}^{=}, \mathrm{SO}_{4}^{=}, \mathrm{F}^{-}, \mathrm{Cl}^{-}, \mathrm{OH}^{*} \text {, etc. }\right) \text {. }
$$

Actinides, more than any other group of elements, form an extensive series of complexes with halogens, oxo-anions, carbonate, sulfate, and phosphate. Complexes of uranium have been studied because of their possible geocnemical role in transport and ore formation. Under oxidizing conditions uranium is one of the most mobile trace elements, mainly due to the hign stability and solubility of its complexes, especially with $\mathrm{CO}_{3}^{2-}$ but also with halogens, phosphate and sulfate. Complexing can change the oxidation potential and therefore the oxidation state of the actinides as well as greatly influencing the solubility, resulting in enhanced modility.

The influence of complexes on uranium mobility is greatly decreased under reducing conditions. Under mildly reducing conditions, carbonate complexes may be effective uranium mobilizers. In general, the potential for complexing is greatly reduced because the actinides precipitate is very insoluble oxides and nydroxides. Under oxidizing conditions in the normal pH range of 6.5 to 8 , Doth carbonate and phosphate complexes are inportant in the natural environment. There are contradictory statements in the literature concerning the stadility of carsonate complexes at elevated temperatures. Langmuir (1978) observes that at $100^{\circ} \mathrm{C}$ and $\mathrm{CO}_{2}$ at $10^{-2} \mathrm{~atm}$, the uranyl carbanate complexes are minor at all $\mathrm{pH}^{4} \mathrm{~s}$. 
At $\mathrm{pH}$ values below 6 and especially below 4 , uranyl complexes with halogens, sulfate and hydroxide become significant mobilizers. The effects of tne carbonate complexes increases at alkaline $\mathrm{pH}$ values.

In summary, under normal near-surface environmental conditions, carbonate and possibly to a lesser degree phosphate complexes are the dominant complexing anions which enhance uranium (and other actinides) mobility. Reducing conditions and $\mathrm{pH}$ values from 7 to 8 would mininize, if not eliminate, the potential impact of complexes on actinide mobility given the usual near-surface concentration of complexing anions in ground water. Very high concentrations of carbonate, phosphate and halogens would greatly increase actinide mobility, probably in almost any geochemical environment. Complexing inhidits sorption.

\section{E. Effects of Temperature on Actinide Geochemistry}

"It has been established that the main effects of temperature are an acceleration of the hydrolysis of a number of the major components of the waste and an increase in radiation yields", (Spitsyn and Balakova, 1979). Hydrolys is of metal ions ( $\mathrm{Fe}, \mathrm{Cr}, \mathrm{Al}$ ) at certain temperatures leads to the formation of crystalline precipitates that prevent transfer of all the waste ions to the solid phase (tends to reduce adsorption by coating open fluid passageways?).

At $200^{\circ} \mathrm{C}$ and above, new crystalline phases appear in shale. The minerals formed would depend on the waste form, accessory minerals in the shale and on the temperature. Since shales are alkali-poor they should act as scavengers for alkali elements (e.g., Rb, Cs) which would react with the clays to form framework silicates, i.e., zeolites and/or feldspars. Pollucite (CsAlSi ${ }_{2} \mathrm{O}_{6}$ ) appears as a dominant reaction product in the $200^{\circ} \mathrm{C}$ experimental range. 
Uxidized uraniun minerals do not occur when waste forms are reacted with organic-rich shale at $200^{\circ} \mathrm{C}$. It seems quite clear that hignly reducing materials such as organic carbon and iron sulfides are sufficient to prevent oxidation of uranium.

Prototype nuclear waste materials react with shale rocks in the presence of water (at $\left.300^{\circ}-400^{\circ} \mathrm{C}\right)$ to form at least 20 reaction product phases. These materials act to buffer or control the further transport of radionuclides Deyond the imediate reaction 2one. Alumino-silicate minerals act as scavengers for cesium and strontium which becomes immobilized as pollucite, powellite and feldspar. Uranium and (by implication) the transuranic elements are strongly influenced by the redox characteristics of the accessory minerals in the rock.

"Snales act as chemical as well as physical barriers to the migration of radionuclides from the immediate vicinity of a waste canister," (even at elevated temperatures $100^{\circ}-400^{\circ} \mathrm{C}$ ) (Freeborn et al., 1980). 


\section{SORPTION}

Sorption is not well understood and it would appear that some of the examples of effective sorption blockage of waste spill migration may be misleading. Sorption, as a group of chemical/mineral interactions tends to be more rate-dependent than other processes discussed in this report. Perhaps sorption mechanisms are better thought of as delayers rather than barriers. In the case of surface spills, a one-shot cnemical release into a nomogeneously porous sorbing media such as organic-rich soil, sorption is an effective short-term barrier.

In subsurface systems the sorption process is less predictable:

1. Continued flow of toxic solutions can circumvent sorption by moving continuously and rapidly through the media such that sorption effect; as studied in controlled experiments do not maximize.

2. Moving solutions equilibrate with sorption media and flush out toxins already sorbed.

3. Solutions flow preferady through few channelways in the bulk surbing media, saturating rock adjacent to channelways and not utilizing tne sorption capacity of the mass.

4. Addition of natural ions (e.g., brines) overpowers availabl: soroing media capacities for toxic retention and/or flushes out already-sorbed toxins.

Notice that sorption mechanisms are generally most effective under the gross conditions that immobilize the important radiotoxins geochemically i.e., reducing conditions, near neutral pH, and low dissolved salt. Mobilizers such as uranyl-sulfate, -floride and-carbonate complexes inhibit tine sorption processes thus increasing their effect on mobility. 
Sorption processes may include:

I. ion excrange,

2. adsorption reactions of ions or complexes,

3. reversible formation of non-soluble complexes,

4. rsible formation of non-soludle complexes and,

5. fuimation of colloid particles.

At least three major inechanisms of sorption appear to dominate over simple cation exchange:

1. Hydrolysis and carbonate complexation appears to enhance general sorption of radionuclides on normally very inert materials such as quartz (Beail and Allard, 1980).

2. Chemi-sorption mechanisms that take place on the surface of certain minerals involve complex formation between an exposed anion on the mineral surface and the cation from solution.

3. Oxidation/reduction reactions between the $\mathrm{Fe}^{2+} / \mathrm{Fe}^{3+}$ couple and certain actinides ( $U, \mathrm{Pu}, \mathrm{Np})$.

But it most systems, nigher sorption was obtained for minerals with high surface area or cation exchange capacity. (Beall and Allard, 1980; Beall et al., 1980).

Tne pH of the aqueous phase seems to be one of the most important parameters that determines the sorption on a solid surface. Generally maximum sorption is at the near neutral pH range of 0.5 to 8.5 .

There are significant differences in static vs. dynamic sorption behavior which suggest the importance of sorption kinetics. Increased sorption is obtained with increased contact time, which implies a kinetic factor, especially for tri- and tetravalent elements. Temperature increases from $25-65^{\circ} \mathrm{F}$ resulted in small increases of sorption (less than a factor of tnree) for clay. granite and ferrous minerals (Allard, 1979). 
"The clay fraction of a natural formation will not retard significantly the migration rates of the corresponding radioisotopes if the contacting phase has high salinity," (Shiao et al., 1979, based on studies of monovalent and divalent ions on either $\mathrm{Na}$ or Ca inontomorillonite). Shiao also studied $\mathrm{Eu}^{3+}$, apparently as an analog to lanthanides and actinides, however, Lynch and Doscn (1980) note that for Eu ${ }^{3+}$, mechanisms other than sorption are important when making experimental measurements.

"The hold up time in the backfill material is at the most some ten thousand years. The only long-lived radionuclides of biological interest that would be sufficiently delayed are ${ }^{90} \mathrm{Sr},{ }^{137} \mathrm{CS}$ and ${ }^{241} \mathrm{Am}$. Thus, the clay barrier is of minor importance in the long term perspective, as far as retention is concerned." (Allard et al., 1979). "The time needed for equilibration (for sorption) is much longer than the transit time of the solution through the pores of the rock. The kinetics of adsorption and de-adsorption may severely effect the dispersion of nuclides in geo-media." (Friedman and Fried, 1979).

Based on studies of Am on hornblende schist and Sr cal glauconite. "Kinetic parameters may be as important to understanding the migration of a nuclide through a geologic media as the equipibrium-sorption value (Kd). Desorption may occur with a rate equal to or less than the rate for adsorption." (Rickert et al., 1979). Radionuclide dispersion through the geologic media surrounding a repository may be enhanced by high aqueous ion concentrations, especially divalent ions from dissolving waste canisters. Na and $C_{a}$ ion loading decreased retention of $C_{S}(10 x), S r(100 x)$ and Eu $(100 x)$ by silicate minerals (Wilihester, 1979).

Figure 17 provides additional information on uranyl adsorption as a function of pH. Table 10 gives experimental data on measured sorption of selected anions on a number of minerals. 


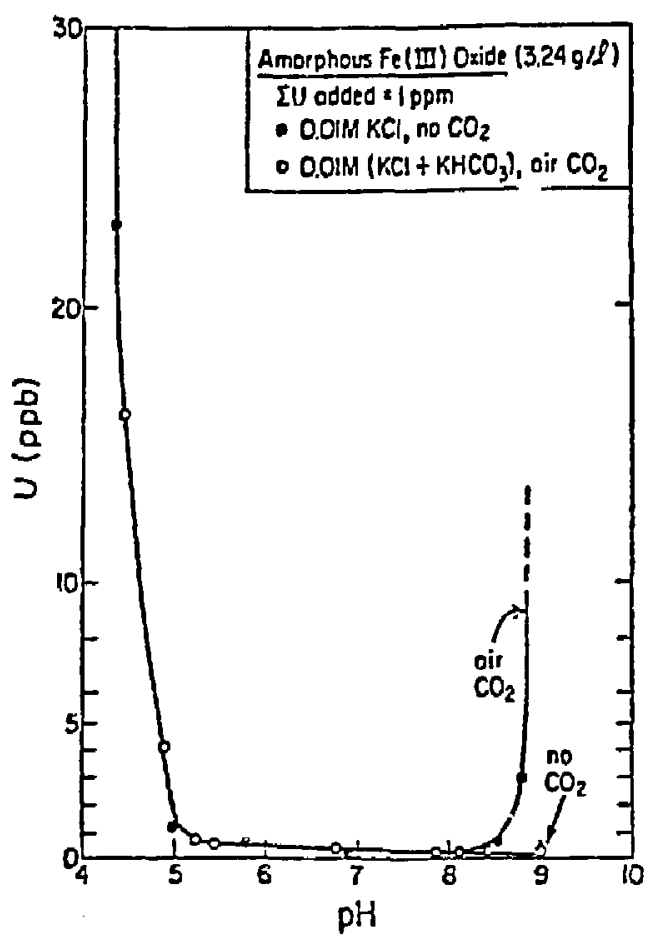

FI6. 17. Adsorption of uranyl onto $x$-ray amorphous ferric oxynydroxide as a function of $\mathrm{pH}$ (oxyhydroxide surface area $285 \mathrm{~m}^{2} / \mathrm{g}, \mathrm{H}_{2} \mathrm{O} / \mathrm{Fe}_{2} \mathrm{O}_{3}$ molar $=1.38$, $P Z C=8.6)$. The "air $\mathrm{CO}_{2}$ " curve $\left(\mathrm{P}_{\mathrm{CO}_{2}}=10^{-3.5} \mathrm{~atm}\right)$ is extrapolated above the last data point, parallel to data trends for two similar experiments (not shown). (from Langmuir, 1978). 


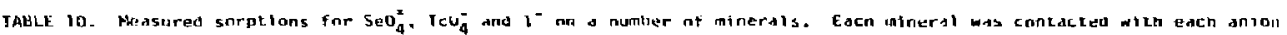
separately. Pesults are given for minly tunse ginerals which silowed measurade takcup ot the anions. The ratios

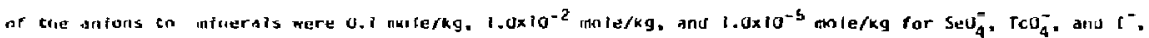
respectively except as noleo.

\begin{tabular}{|c|c|c|c|c|c|c|}
\hline Ninerals & Adverax findide firnula & $\begin{array}{l}\text { Aninus } \\
\text { atrached }\end{array}$ & $\begin{array}{c}\text { Uriginal } \\
\text { concentratian } \\
\text { altacued } \\
\text { (rimle/kg mineral) }\end{array}$ & $\begin{array}{l}\text { Nuaber of } \\
\text { desarptintis } \\
\text { attempted }\end{array}$ & 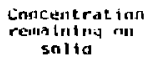 & 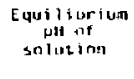 \\
\hline
\end{tabular}

\begin{tabular}{|c|c|c|c|c|c|c|}
\hline \multicolumn{7}{|l|}{ Silicatus } \\
\hline Auglet & & $\begin{array}{l}\mathrm{S}_{\mathrm{SOU}}= \\
\mathrm{I} C \mathrm{U}_{4}-\end{array}$ & $\begin{array}{l}4.0 \times 10^{-2} \\
1.9 \times 10^{-3}\end{array}$ & $\begin{array}{l}2 \\
1\end{array}$ & $\begin{array}{l}3.2 \times 10^{-2} \\
1.4 \times 10^{-3}\end{array}$ & $\begin{array}{l}4.4 \\
t i .1\end{array}$ \\
\hline Horntalende & 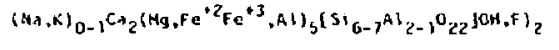 & $\mathrm{SeO}_{4}=$ & $2.2 \times 10^{-2}$ & 2 & $1.0,10^{-c}$ & 8.2 \\
\hline arotite & 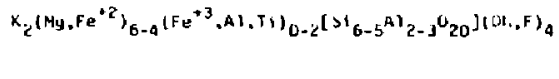 & $\mathrm{IcO}_{4}^{-}$ & $\begin{array}{l}2.4 \times 10^{-6} \\
9 \times 10^{-5} \\
5 \times 10^{-6}\end{array}$ & $\begin{array}{l}0 * \\
0 \\
0\end{array}$ & - & 7.8 \\
\hline Vemicullte & 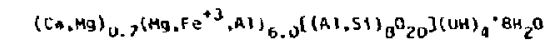 & $\mathrm{SeO}_{4}^{2}$ & $3.2 \times 10^{-2}$ & 4 & $2.0 \times 10^{-2}$ & 0.0 \\
\hline Kanlinite & $\therefore{ }_{4}\left[>{ }_{4} a_{10} J(v H+\}_{B}\right.$ & $\mathrm{TCO}_{4}^{-}$ & $\begin{array}{l}3 \times 10^{-4} \\
8 \times 10^{-6}+4 \\
8.0 \times 10^{-5} \ldots\end{array}$ & 0 & - & 0.0 \\
\hline
\end{tabular}


TABLE 10 (continued)

\begin{tabular}{|c|c|c|c|c|c|c|}
\hline Minerals & Approximate taminsio & $\begin{array}{l}\text { Aninons } \\
\text { atencined }\end{array}$ & 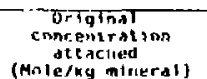 & 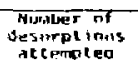 & $\begin{array}{l}\text { Concentratiant } \\
\text { remaluing un } \\
\text { sabid }\end{array}$ & $\begin{array}{l}\text { Enimlarion } \\
\text { pri nit } \\
\text { solution }\end{array}$ \\
\hline
\end{tabular}

Sulfides, corbonatrs, Punsphices

balena pus

Sphalertle [2n.te)s

enicite caca

is

Snithsmitite Znco,

Apatite $\quad \mathrm{CO}_{5}\left(\mathrm{POO}_{\mathrm{d}} \mathrm{Y}_{3}^{(\mathrm{OH}, \mathrm{F}, \mathrm{Cl})}\right)_{2}$

\begin{tabular}{|c|c|c|c|c|}
\hline $\mathrm{SeO}_{4}$ & $5 \times 10^{-3}$ & U & - & 0.1 \\
\hline $\mathrm{IcO}_{4}^{-}$ & $2.7 \times 10^{-7}$ & 0 & - & - \\
\hline 3 & $3.0 \times 10^{-4}$ & u & - & - \\
\hline $\sec _{4}=$ & $3.9 \times 10^{-2}$ & 1 & $3.9 \times 10^{-2}$ & - \\
\hline $700^{\circ}$ & $2.2 \times 10^{-5}$ & o & $\cdot$ & $\cdot$ \\
\hline${ }_{\mathrm{SeO}}$ & $9.7 \times 10^{-1}$ & 1 & $1.5 \times 10^{-3}$ & 8. \\
\hline
\end{tabular}

$500{ }_{4}^{\circ} \quad 9.8 \times 10^{-6}$

$100^{-} \quad 3.2 \times 10^{-5}$

500.

$2.5 \times 10^{-2}$

$0 \quad 1.5 \times 10^{-3}$

o

-

Meinlse nxyaps

Copper

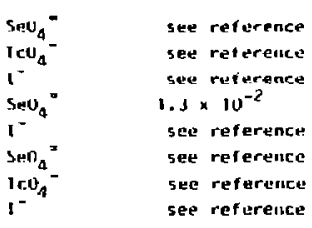

$\mathrm{CuO}_{\mathrm{Cu}_{2} \mathrm{O}}^{\mathrm{Col}}$

- Spant anenus desarptian accurred.

* $1 \times 19^{-5}$ males $\mathrm{TcO}_{\mathrm{n}}^{-} / \mathrm{ky}$ minaral.

(frrm olrd and Lagate lyou) 


\section{HYOROTHERMAL ORES}

Geochemical work has been focused for decades on the characterization of the hot aqueous solutions which transport and deposit metallic ore elements. Geochemical conditions whicn allow mobility of metal ions prior to ore deposition would jeopardize the stability and integrity of a waste disposal site. Ore solutions are generally characterized as follows:

- Aqueous solutions saturated with silica and of ten containing high [NaCl].

- Temperature range: 50 to $550^{\circ} \mathrm{C}$.

- Pressure range: up to 2,000 atm.

- $\quad$ PH: neither strongly acid nor strongly alkaline.

Interestingly, the order of solubilities for ore minerals provides no explanation for the observed order of deposition. Of the various suggestions for explaining metal soludility in ore solutions, the most promising is increased solubility resulcing from the formation of complex ions and molecules. Ore solution behavior may be characterized in terms of species modility and immobility as follows:

A. Mobility (active ore solutions)

- Salinity $3 \%-50 \%$ dissolved solids by weight.

- Major aqueous components: $\mathrm{Na}, \mathrm{K}, \mathrm{Ca}, \mathrm{Cl}$.

- $\quad 0.1 M$ carbonate; $0.1 M$ sulfur species; $0.01 M$ ammonia; weakly alkaline to somewhat acidic.

- Mecnanicism for transport: sulfide complexes at low temperature; chloride complexes at high temperature with generally increasing stability above $200^{\circ} \mathrm{C}$. 
- Evolving fluids: Field and experimental studies and data from ${ }^{87} \mathrm{Sr} /{ }^{86} \mathrm{Sr}$ ratios indicate that anion exchange reactions, between solution and minerals, such as feldspar, micas and clays must proceed continually so that a solution changes in composition as it moves... A hydrothermal fluid is therefore an evolving or changing entity, influenced principally by temperature and the rock through which it passes (Skinner, 1979; Stanton, 1972).

It appears that a toxic metal waste disposal situation should assume some mobility of fluids and that the rates and distances of that mobility must be controiled.

B. Inmobility (ore deposition)

- Chemical reactions between maving solutions and the rocks lining the channelways must de a major cause of precipitation. These are:

a) Exchange reactions which change anion and cation concentration.

D) Addition of reduced sulfur from black shale would cause an immediate precipitation of sulfide minerals.

c) Change in oxidation state which can be influenced by metamorphic reactions (i.e., serpentinization) and the addition of carbonaceous matter or mixing with ground waters.

- Drop in temperature - reduced stability of complexes, e.g., chloride complexes.

- Orop in pressure - reduces the amount of dissolved gases, e.g., $\mathrm{CO}_{2}, \mathrm{NH}_{4}, \mathrm{CH}_{4}$.

- Change in $\mathrm{pH}$ - (associated with above changes) hydrogen ion consumers are carbonates, feldspars, mafic minerals (Barnes, 1979). 
C. Supergene Processes (Remodilization of metals in the weatnering/ oxidizing environment)

The mooility of metal ions in the zone of weathering is determined by the composition of both the waters and the country rock. Tne fundamental process is oxidation, but since tne oxidation of sulfides produces hydrogen ion and sulfate, both Eh and $\mathrm{pH}$ are important.

The nost rock environment is especially important in the oxidation of sulfides in the supergene process. Some metals that would be leached from a siliceous host are retained in calcareous rocks (Park and McDiarmid, 1975).

Sulfide-free oxidizing meteoric waters leacn such elements as zinc, molybcenum, and uranium from igneous rocks leaving beh $A$ stable oxidation products of $\mathrm{Fe}, \mathrm{Al}, \mathrm{Ti}$, and $\mathrm{Cr}$. Molybdenum, $\mathrm{Zn}$ and $\mathrm{Ag}$ are especially soluble in sulfate solutions, but under favorable conditions they furm slabie oxidation products in limestone. Similarly, copper, which is relatively mooile in sulfate waters that circulate through siliceous igneous rocks, forms practically insoluble carbonate minerals in calcareous environments. Iron and lead oxidize to staple compounds in both siliceous and calcareous rocks, and are generally retained in the zone of weathering. Most arsenic compounds, in contrast with those of antimony, are relatively soluble and consequently are leached from the zone of weathering. Copper and silver when mobilized in the oxidizing zone will largely redeposit under reducing conditions, generally at the water table as a sulfide mineral phase, thus the basis for the supergene ores or enrichments of these metals.

D. Hydrothermal alteration (Buik-rock mineral changes due to hydrotnermal activity)

Ore-bearing solutions evolve as they move. Given the proper country rock and conditions, the alteration reactions can significantly inf luence mooility. Certain alteration /silicification, dolomitization and 
recrystallization) may prepare the ground (chemically and physically) for precipitation of ore. Example: silicification can convert a soft, impermeasle rock to a more brittle rock suoject to fracture and therefore more susceptible to ore solutions. Silicified rock terrain should be avoided for waste sites because of such tendency to allow fracture access of oxidizing ground waters. Conversely, such a rock mass could serve if disposal is in a permeable silicified rock confined by soft, reducing, relatively impermeable rock strata (silica alteration zones surrounded by clay alteration with pyrite). Alteration products are an integral part of the mineralization process. Detailed studies of mineral alteration associated with ore deposits provide clues for the conditions over which the deposit formed. A discussion of alteration reactions is beyond the scope of this project but may provide a fruitful avenue of investigation, Alteration reactions can significantly influence the Eh, $\mathrm{pH}$ and cation/anion characteristics of ore solutions. Hydrous silicates (clays, micas, etc.) are abundant products of alteration accompanied by volume increase relative to original rock, a factor of ten considered as a progressive natural sealant process around a not waste package. Increased sorption effects ascribed to such clay alteration is not a likely benefit, however, as dealt with in Section VI of this report.

Tables 11 and 12 illustrate natural variation in hydrothermal solutions. In sumary, this section suggests that waste behavior generalizations can De orawn from the abundant literature on hydrothermal solutions. But these geocnemical systems are even more complex than those affecting the behavior of the selected radwaste elements and further treatment will not oe attempted nere. 
TABLE 11. Compositions of some modern and ancient nydrothermal solutions.

Concentrations in ppm. $1=$ Salton Sea geothermal brine; $2=$ Cheleken geotherinal brine; $3=0$ oil field brine, Gaddis Farins 0-1 well, Lower Rodessa reservoir, central Mississippi, $11,000 \mathrm{ft} ; 4=$ fluid inclusion in fluorite, Cave-in-Rock District, $111 . ; 5=$ fluid inclusion in sphalerite, OH vein, Creede Colo.; $\sigma=$ fluid inclusions, core zone at Binghan Canyon.

\begin{tabular}{|c|c|c|c|c|c|c|}
\hline \multirow[b]{2}{*}{ Element } & \multicolumn{3}{|c|}{ Modern solutions } & \multicolumn{3}{|c|}{ Ancient solutions } \\
\hline & 1 & 2 & 3 & 4 & 5 & 6 \\
\hline$C l$ & 155,000 & 157,000 & 158,200 & 87,000 & 46,500 & 295,000 \\
\hline $\mathrm{Na}$ & 50,400 & 76,140 & 59,500 & 40,400 & 19,700 & 152,000 \\
\hline $\mathrm{Ca}$ & 28,000 & 19,708 & 36,400 & 8,600 & 7,500 & 4,400 \\
\hline$k$ & 17,500 & 409 & 538 & 3,500 & 3,700 & 57,000 \\
\hline$S r$ & 400 & 636 & 1,110 & - & - & - \\
\hline 践 & 235 & $-{ }^{a}$ & 51 & - & - & - \\
\hline Li & 215 & 7.9 & - & - & - & - \\
\hline Ro & 135 & 1.0 & - & - & - & - \\
\hline Cs & 14 & 0 & - & $=$ & - & - \\
\hline Mg & 54 & 3,080 & 1,730 & 5,600 & 570 & - \\
\hline$B$ & 390 & - & - & $<100$ & 185 & - \\
\hline$B r$ & 120 & $52 \overline{0} .5$ & 870 & - & - & - \\
\hline I & 18 & 31.7 & - & - & . & - \\
\hline$F$ & 15 & - & - & - & $=$ & - \\
\hline $\mathrm{NH}_{4}$ & 409 & - & 39 & - & - & - \\
\hline $\mathrm{HCO}_{3}^{-}$ & $>750$ & 31.9 & - & - & - & - \\
\hline $\mathrm{H}_{2} \mathrm{~S}$, & $16^{b}$ & 0 & - & - & $=$ & - \\
\hline $\mathrm{SO}_{4}^{2-}$ & 5 & 309 & 310 & 1,200 & 1,600 & 11,000 \\
\hline $\mathrm{Fe}$ & 2,290 & 14.0 & 298 & - & - & 8,000 \\
\hline inn & 1,400 & 46.5 & - & 450 & 690 & - \\
\hline Zn & 540 & 3.0 & 300 & 10,900 & 1,330 & - \\
\hline $\mathrm{Pb}$ & 102 & 9.2 & 80 & - & - & - \\
\hline $\mathrm{Cu}$ & 8 & 1.4 & - & 9,100 & 140 & - \\
\hline
\end{tabular}

a Not determined.

b Sulfide present; all $\mathrm{S}$ reported as $\mathrm{H}_{2} \mathrm{~S}$.

(From Skinner, 1979) 

TABLE 12. Representative Total (arialytical) Cancentrations in Hydrothermal
Solutions.

\begin{tabular}{|c|c|c|c|c|c|c|c|c|c|c|}
\hline & & & omplex-farming & Species & (nolalitfes) & Met & is (ppm) & & & \\
\hline Location & $\Sigma \mathrm{C} 1$ & $2 \mathrm{SO}_{4}$ & $\Sigma^{2}=$ & $\mathrm{ENH}_{3}$ & $2 \mathrm{NO}_{3}$ & $2 n$ & Pb & Cu & $\mathrm{pH}$ at & $T^{\circ} \mathrm{C}$ \\
\hline $\begin{array}{l}\text { Ore Deposits } \\
\text { Creede. colo. }\end{array}$ & $0.9-1.9$ & $0.02-0.3$ & $10^{-3.8}-10^{-3.7}$ & - & . & $10^{2.8}$ & $\begin{array}{l}10^{-3.3} \\
(\mathrm{Fe}: 1)\end{array}$ & $10^{-2.8}$ & 5.4 & 250 \\
\hline Darwin, Cal. & $>4.3$ & -0.01 & - & - & $0.15 \pm 0.06$ & $<7700$ & - & 740 & $4.8-6.7$ & 350 \\
\hline Yatani. Japan & $0.1-0.2$ & $10^{-6}-10^{-10}$ & $\sim 10^{-2}$ & - & $-\quad--1$ & - & - & - & -6 & 250 \\
\hline Providencia, Mex. & $0.03->4.3$ & 0.7 & - & - & - & $220-890$ & - & $<70-530$ & - & 300 \\
\hline Echo Bay. N.H.T. & -7 & $10^{-2}-10^{-3}$ & $-1,7$ & - & to 0.1 & & (Ag: $0.1-1$ & .1 & $4.2 \pm .5$ & 200 \\
\hline Kuroko Deposits, Japan & $0.4-1.5$ & - & $<10^{-1.7}$ & - & $\cdot$ & - & - & - & $5.5 \pm .5$ & 250 \\
\hline Pasto Bueno, Peru & 0.4 to 3.5 & & & & & & & & - & $175-290$ \\
\hline $\begin{array}{l}\text { Tribag, Ontario } \\
\text { Messina, S. Africa }\end{array}$ & $\begin{array}{ll}- & \end{array}$ & $\mathrm{HH}_{2} \mathrm{~S}$ & $10^{-2}-10^{-3}$ & - & - & & & & - & - \\
\hline S.H.Wiscansin, U.S. & $4.2->5.1$ & - & $>10^{-3}$ & - & $11.03-0.9$ & 8700 & -500 & 400 & $6.0 \pm .3$ & $\overline{150}$ \\
\hline Eureka, Col. & $0.1-0.6$ & $10^{-2.2}$ & $10^{-1.4}$ & - & $1.01-0.2$ & $>1-<1000$ & $>1-41000$ & (Au $10^{-2}-10^{-3}$ ) & $4.3-5.9$ & 300 \\
\hline \multicolumn{11}{|l|}{ Geothermal Fluids } \\
\hline E) Jatto, Chile & 0.2 & - & $10^{-3.7}$ & $10^{-3.9}$ & $10^{-1.1}$ & - & - & - & $\overline{7}$ & $\begin{array}{r}263 \\
25\end{array}$ \\
\hline Imperial Valley & & & & & & & & & & \\
\hline Salton Sea, Cal. & 2.4 & $<10^{-4.0}$ & $10^{-3.7}$ & $10^{-3.5}$ & $0^{-3.0}$ & 380 & 70 & 3 & $\therefore$ & 240 \\
\hline Cerro Prfeto, Mex. & 0.3 & $10^{-3.8}$ & - & - & $10^{-3.0}$ & - & - & - & $\begin{array}{l}6.1 \\
-\end{array}$ & $\begin{array}{r}25 \\
100\end{array}$ \\
\hline Che leken, U.S.S.R. & 3.1 & $10^{-2.8}$ & $10^{-4.0}$ & - & $10^{-2.4}$ & 0.19 & 3.6 & 0.9 & $\begin{array}{l}7.9 \\
5.5\end{array}$ & $\begin{array}{l}25 \\
54\end{array}$ \\
\hline & 2.9 & $10^{-2.5}$ & - & - & $10^{-3.4}$ & $2.3-4.7$ & 3.6 & 0.8 & 5.4 & 80 \\
\hline Central Miss. U.S.A. & 5.9 & - & - & $10^{-2.1}$ & & 124 & 6.8 & & & 158 \\
\hline Eastern Kansas, U.S.A. & 6.0 & $10^{-1.9}$ & $10^{-2.9}$ & $10^{-3.0}$ & $10^{-2.4}$ & .06 & 1.7 & .14 & 7.03 & -20 \\
\hline & 4.0 & $10^{-2.9}$ & $10^{-2.2}$ & $10^{-3.4}$ & $0^{-2.2}$ & .13 & 1.1 & $c .1$ & 6.88 & -20 \\
\hline
\end{tabular}

(Af ter Skinner, 1979) 


\section{DEPTH}

The gross changes of geochemical variables associated with increased depth are, of course, temperature and pressure increase (plus simple distance to the biosphere). But other major variables change with the temperature/pressure gradients, namely:

1. Porosity

2. Permeability

3. Eh

4. $\mathrm{pH}$

5. Salinity (especially chloride)

6. Sorption

As shown in $\mathrm{Fig} .18$, pressure increase is equated with depth into the earth, along with examples of high, medium and low natural thermal gradients possible in crustal environments. Recall that in shallow/moderate depths, the pressure of an essentially open (to the surface) system would be atmospneric plus hydrostatic (groundwater) pressure. At moderate/great deptins or in very weak rocks with sufficient time allowed, pressure will approacn that of the overlying rock column (litnostatic).

\section{A. Porosity/Permeability/Depth Relationships}

Initial porosities for shales at the time of deposition range frum 0.6 to 0.9 and most of the reduction in porosity occurs with in the upper $300 \mathrm{~m}$ of burial. Sands are less yariabla (Fig. 19). At depths of $3000 \mathrm{~m}$, porosity ranges from 0.2 to nearly 0.0 for sands on sliales. Porosity reversals are nated in zones of sediments that have not followed the usual compaction-depth sequence because their low permeability has prevented the escape of interstitial water at normal rates with burial (Hanor, 1979). 


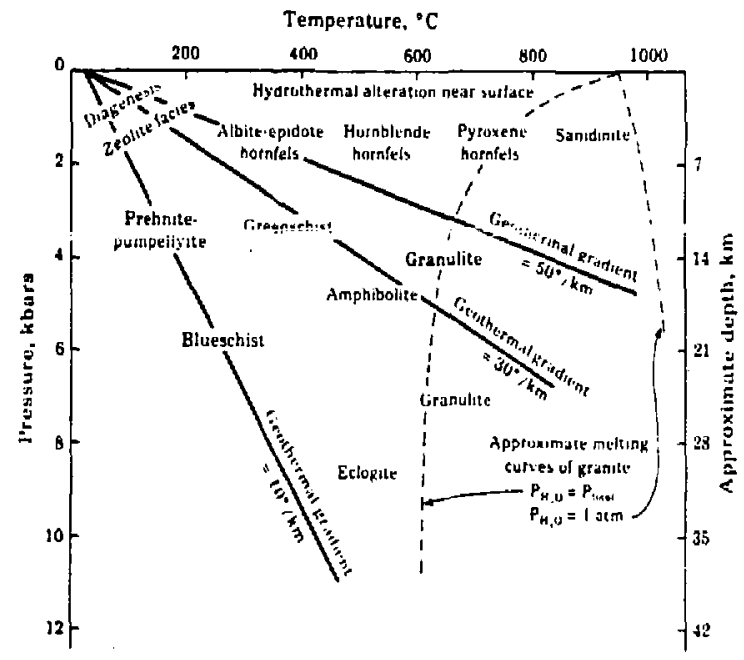

F16. 18. Ap, sroximate pressure-temperature fields of the principal metamorphic facies. The three solid lines show $\rho r_{\text {r }}$ sible values of the geothermal gradient: the mean of measured values is about $30 \%$, the maximum about $50 \% \mathrm{~km}$, the minimum about $10 \% \mathrm{~km}$. The dashed lines show temperatures of incipient melting of granite, under water-vapor pressure equal to total pressure and water-yapor pressure equal to l atm. Between the two lines is the region where differential melting of high-grade metanorphic rocks may occur.

(In Krauskopf, 1967) 
A significant volume of water is released during normal sediment compaction and diagenesis (lithification). Seventy-five percent of this water from shale is normally expelled during shallow burial from $0.1000 \mathrm{~m}$, and a snale is likely to be essentially staoilized and "sealed" at depths of $300 \mathrm{~m}$ (Fig. 19). For sandstone, burial to $3000 \mathrm{~m}$ is required before $75 \%$ of this water is expelled (Hanor, 1979).

Note: Low porosity and perneability are not necessarily desirable for the inmediate area of the waste disposal site. Generally a critical factor for the aeposition of ores and sorption reactions to take place is relatively high surface area (i.e., a generally porous/permeable strata). Permeability can be an important control since most mineralogic changes (chemical changes that would aid precipitation and adsorption) are not isochemical. The rocks must oe open for contact and for exchange witn constituents in the solution. However, too porous/permeaple strata would allow flow rates to be too high and not allow for enough time for potential cortact (adsorption) and excnange. Likely, a nign porosity coupled with low permeability, such as may exist in interpedded shale units or shales interbedded with certain sandstones, would be ideal.

In general, ore deposits are localized in rock strata of intermediate porosity and perneability. Often the process of ore deposition and alteration greatly influences these properties. High fracture permeability would be nearly always undesirable.

Generally, permeability and porosity decrease witn deptn of burial owing to pressure of overlying rocks and to the cementing action of mineral-laden waters. Many mines are ory in their lower levels. The lower depth limit varies considerably and may be anywhere from a few feet to several thousand feet below the surface. 


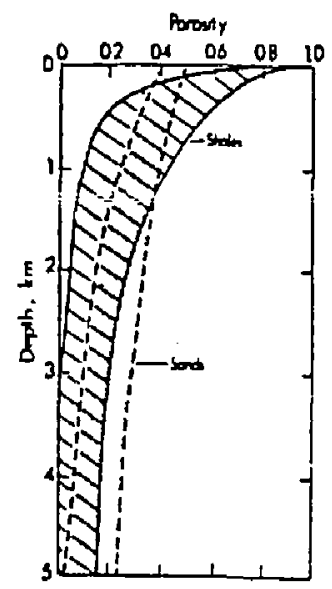

FIG. 19. Range in porosity of shales (ruled area) and sands (stippled area) as a function of depth of burial. Based on data of Perrier and Quiblier (1974). 
Neverthe?ess, the preponderance of evidence indicates that solutions in large amounts do move through massive rocks at depth. Fluids under pressure are able to fracture and work their way through rock. Depth, due to increasing hydrostatic pressure may work against inmooility. Studies support the contention that fluids are able to fracture rocks and pass through them to areas of lower pressure. (Park and MCDiarmid, 1975).

One cannot help being impressed by the movement of large amounts of hot fluids through relatively impermeable rocks e.g., in the Big Geyser Area, California (and the many broadly minera! ized and altered nydrothermal ore districts). Park and Mcoiarmid (1975) concluded that "ore-bearing fluids are aole to move through dense rocks oy working around individual grain boundaries or by other means."

\section{B. Uepth-related Salinity:}

Salinity of ten increases with depth in sedimentary basins (Fig.21). Typically, the rate of salinity increase diminishes with depth, and maximum odserved salinities level off to a value that is characteristic for each basin (Dickey, 1969; Hanor, 1979). Significant reversals in salinity with depth have oeen found in Cenozoic sands and shales of the Gulf Coast with iower salinity in sediments of abnormally high fluid pressures. In tne Illinois Basin (Figs. 20 and 21) chloride increases with depth and there is an approximate depth sequence, observed in many other basins as well. Shallow waters are nigh in bicarbonate and su'fate, progressing to sodium chloride waters with increasing depth. In zones characterized by hydrostatic fluid pressure, salinities in shales are a factor of $1 / 4$ to $1 / 10$ lower than in adjacent sands. Most nigh-sulfate formation waters are confined to relatively snallow depths (Hanor, 1979). 


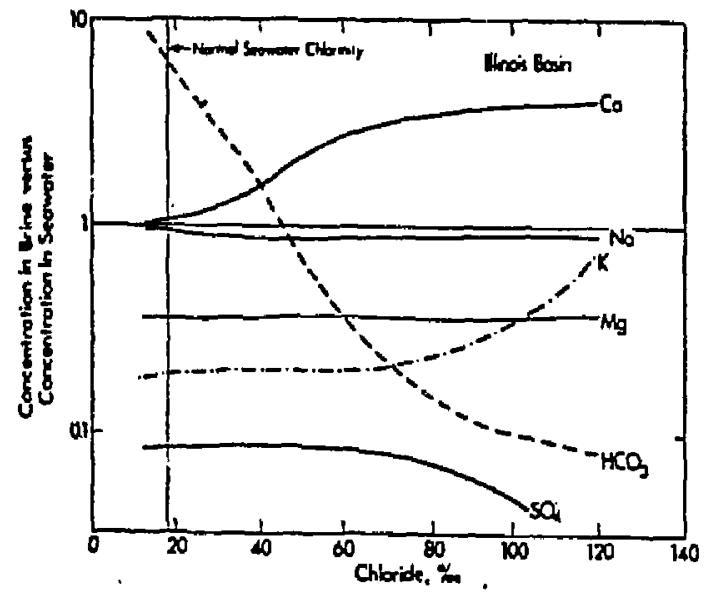

FIG. 20. Variation in major element concentration of waters in the Illinois basin as a function of dissolved chloride content. Values are normalized with respect to sea water of the same chloride content.

(Hanor, 1979) 


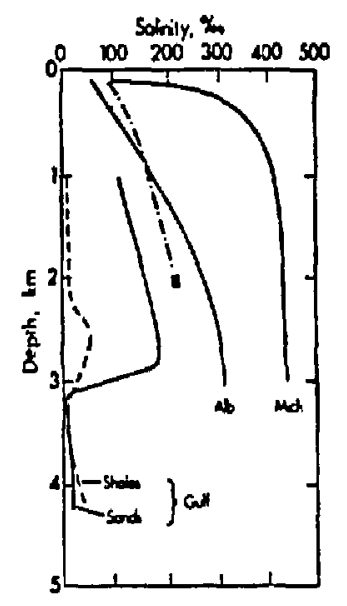

FIG. 21. Maximum observed salinities at various depths in the Illinois, Michigan, and Alberta basins. The two profiles on the left show the variation in salinity in shale sands in the Manchester field, Louisiana Gulf Coast (In Hanor, 1979). 


\section{Depth-related pH:}

Temperature increases with depth, and $\mathrm{pH}$ is generally considered to decrease as temperature increases. Hanor (1979) states that the pH of pure water will be 5.8 at $150^{\circ} \mathrm{C}$. The diagram (Fig. 22) from Krauskopf (1967) shows a confusing effect of temperature on $\mathrm{pH}$. Because of the increased ionization constant of water to a maximum at $230^{\circ} \mathrm{C}$, the neutral pH point is then 5.7 . Krauskopf states that with increasing temperatrme water at first becomes ooth a petter acid and a better base. It is likely that increased geochemical mobilities, dependent on decreasing $\mathrm{pH}$, will result due to this depth function (this point deserves some review).

Field data from the Stripa Granite shows an increase of $\mathrm{pH}$ with shallow/moderate depth. At $10 \mathrm{~m}, \mathrm{pH}=5.15$ and at $801-838 \mathrm{~m}, \mathrm{pH}=9.60$ (Fritz et al., 1980). This is an unusually high natural pH. Thermal gradient in the Stripa area is low. Recall that relative to actinide mobilization significant $\rho H$ variance either side of neutral will increase mobility.

\section{Depth-related Eh:}

The redox potential for deep ground water (approx. $500 \mathrm{~m}$ ) in Stripa granite is largely determined and buffered by the presence of iron-containing minerals. For the expected pH ranges of 7.2 to 8.5 , the Eh value would be in the range of -70 to $-380 \mathrm{mV}$ in undisturbed ground water from granitic terrain due to the $\mathrm{Fe}^{3+} / \mathrm{Fe}^{2+}$ equilibrium. Under these conditions:

$$
\begin{aligned}
& \mathrm{Pu} \text { exists as } \mathrm{Pu}^{3+} \text { or } \mathrm{Pu}^{4+}, \\
& \mathrm{Np} \text { as } \mathrm{Np}^{4+} \text {, } \\
& \text { TC as } \mathrm{TC}^{4+} \text {, and } \\
& U \text { probably as } \mathrm{U}^{4+} \text {. (Allard et al., 1979) }
\end{aligned}
$$

The above reducing conditions would tend to minimize the mobility of the actinides. 


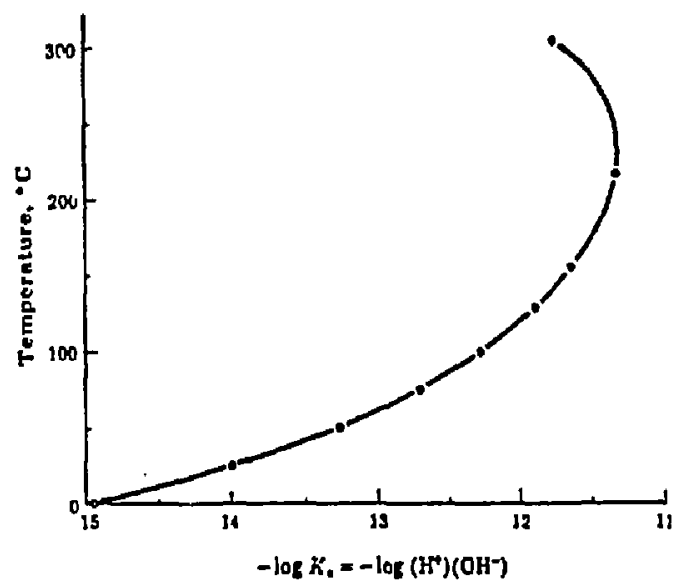

FIG. 22. Change of the ionization constant of water with temperature. (In Krauskopf, 1967). 
The following discussion is from Park and MCDiarmid (1975)

"In tectonically stable regions, the oxidation zone generally extends to the water table, especially if the country rocks are permeable. Recent faulting, fluctuating water table or impervious wall rocks may modify the pattern of oxidation.

The position and permanence of the water table is critical because sulfides are generally stable in the slightly alkaline, moderately reducing environinent below the ground water table. In humid climates the sulfide zone (reducing) may be a few feet from the surface; in arid environments, where the water table is likely to be deep, the lower limit of oxidation may extend $2000-3000 \mathrm{ft}$. below the outcrop.

The role of permeability in oxidation is strikingly demonstrated at the Tsumeb Mine, SW Africa, where d nearly vertical ore pipe that cuts througn steeply dipping sediments is oxidized in the upper and lower parts but is unweathered at the intermediate leveis. The unoxidized part of the pipe is protected from ground water by relatively iripermeable strata. Oxidation along the deep brecciated (fractured) stratum is so efficient that the lower part of the pipe is more thoroughly oxidized tnan inucn of the shal low weathered zone."

Note: What one gains geochemically from depth in terms of waste isolation may depend significantly on the rock strata in which the waste will be put. It is conceivaole that a shale at a depth of 100 to $300 \mathrm{~m}$ would exhibit better properties in terms of sealing (very low solution mobility) than a sandstone or a granite at 1000 to $3000 \mathrm{~m}$.

\section{E. Other Depth Functions:}

$\mathrm{CO}_{2}$ content, which is of critical importance to the geochemical mobility of many radionuclides, is in a simple sense increased with the 
increased pressure of depth. The actual source of much $\mathrm{CO}_{2}$ is limited by depth. Diagenetic/metamorphic reactions (changing calcite and quartz into calcium-silicates $+\mathrm{CO}_{2}$ ) which take place at shallow depth and moderate temperature (approximately $300^{\circ} \mathrm{C}$ ) are 1 imitad by depth-pressure increase in a closed system. A temperature of about $600^{\circ} \mathrm{C}$ is necessary for this reaction at a pressure equivalent of 3000 meters depth (Fig. 23). Note that this effect increases rapidly through depths of 0 to 2000 meters.

Melting puints of rocks decrease with depth due to fluxing by increased $\mathrm{H}_{2} \mathrm{O}$ pressure.

F. Sunmary of Depth Implications to Waste Isolation:

The question of depth as related to burial of wastes can be answered with respect to the variation of geochemical functions as follows.

1. Low porosity and permeability generally associated with depth are not necessarily desirable for the immediate area of tne disposal site.

2. Decreased $\mathrm{pH}$ at greater depths would likely ;movide increased geochemical mobilities. Relative to actinides, significant pH variation either side of neutral will increase mobility.

3. Reducing conditions associated with greater depths would tend to minimize mobility of the actinides. But these conditions depend on the type of rock strata in which wastes will be placed. Shales exhibit favorable geochemical conditions at relatively shallow depths. 


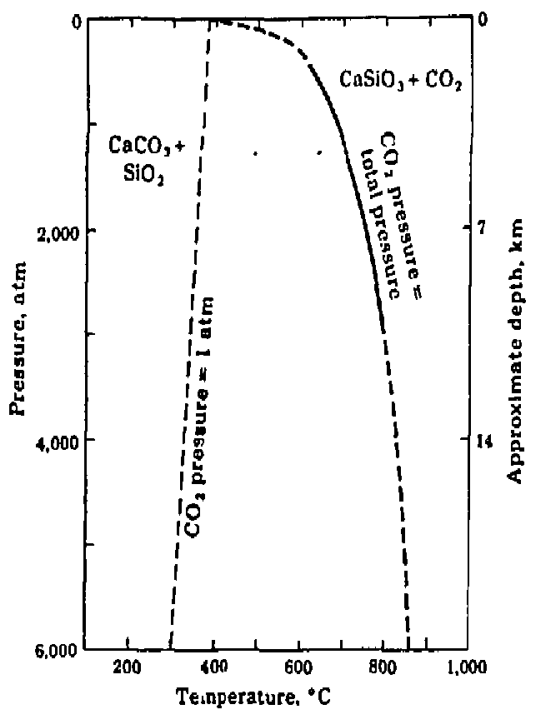

FIG. 23. Equilibrium curves for the reaction $\mathrm{CaCO}_{3}+\mathrm{SiO}_{2}+\mathrm{CaSiO}_{3}+\mathrm{CO}_{2}$ at $P_{\mathrm{CO}_{2}}=P_{\text {total }}$ (heavy line) and $P_{\mathrm{CO}_{2}}=1$ atm (light line). Heavy solid line experimentally determined. Dasined lines extrapolated or theoretical. At P-T values between the two lines, calcite and quartz are stable if $\mathrm{P}_{\mathrm{CO}_{2}}=\mathrm{P}_{\text {total }}$, and wollastonite is stable if $\mathrm{P}_{\mathrm{CO}_{2}}=1$ atm.

(In Krauskopf, 1967) 


\section{CONCLUSIONS ANO SUGGESTIONS FOR FURTHER HORK}

A. Conclusions

The geochemical approach leads to the conclusion that radioactive wastes could be immobilized in a quite normal, easily obtainable geologic/geochemical situation. That situation should consist of:

- Reducing Environment

- Moderate pH (6.0-8.5)

- $\mathrm{LOW} \mathrm{CO}_{2}$

- Low salt (especially chloride)

- High porosity, low permeability

The above conditions do not imply considerable depth. For shale, which appears to be the rock-type most closely associated with optimal geochemistry, the optimum depth is likely to be less than $1000 \mathrm{ft}$.

The prime variable for radionuclide immobility is the Eh. Reducing conditions should prevail unless the isolation is to depend on physical/hydrological barriers rather than geochemical stability; and it is our contention that when coupled with those above, reducing conditions essentially ensure immobility even when physical/hydrological conditions are otnerwise poor.

The very long-term stability $\left(10^{7} \cdot 10^{9}\right.$ years $)$ of important elements at OKlo (natural fission reactors) and of uranium ore deposits, indicates the effectiveness of low Eh in apparently varied and not necessarily optimum pnysical/hydrologic conditions. An isolation site in shale, if selected to provide long-term geologic stability relative to exhumation by erosion or disturoance by tectonic effects, could be quite shallow (less than $1000 \mathrm{ft}$ ). 
Appropriate geochemical conditions may be present below any stable water table. Obviously very long-term prediction of water table levels or non-incursion of circulating oxidizing waters is difijcult, thus moderate depth provides a time-rate insurance that is likely to be valid. This is significant also in terms of the geologic mobilities of iodine and radon.

Sorption is perhaps over-rated as a barrier process relative to long-term radioactive waste isolation. Sorption processes are effective in nomogeneously porous and permeable sorbing materials suen as soils under slow solution flow (leaks) or one-shot situations (spills). In the long-term subsurface situation, sorption can be important but can also be rendered ineffective by expected natural processes. At best sorption should be considered a moderate-term delay ( $10^{4}$ years) rather than a long term barrier. Interestingly, sorption is maximized under the same conditions that maximize other geocnemical immobilizing processes so these processes are mutually supportive.

Organic and pyritic shales are generally the best waste host rocks in terms of parameters used in this study.

Base metal behavior, as seen in our brief look at theoretical nydrothermal ore deposition and geothermal systems, appears to be similar to the nuclides studied in their tendencies toward immobility under reducing conditions and some mobility in oxidizing systems. These distinctions are less clear-cut for hydrothermal metals in both the reducing and oxidizing situations, and the role of complexing is likely even more significant than for the nuclides studied. Empirical data (as in several taoles following) suggests massive mabilities of base metals, probably even under reduced conditions. More empirical data would likely support the implication that metals are mobile even where they should theoretically stay put. 
The m-factors identified in this report are easily interpreted and reproduced, but are not yet in a form useful for broad derivation and application to the hazard index formula. The $+m,-m$ designations must be quantified numerically in order to interface with the Smith et al. (1980) geotoxicity hazard index. For that matter, the m-factors based on geochemical functions should be reducible to broader, more easily identifiable geologic conditions as related to specific sites.

In the geochemical review work for this report, we felt that it is not possiole in a theoretical approach to ensure that the subile geochemical effects on waste behavior are entirely allowed for. The analog (empirical) approach, if several models are used, is likely to be superior to the tneoretical approach in allowing for geochemical/thermodynamic variables such as:

- Kinetics (reaction rates)

- Reaction potentials

- Reversibility of reactions and

- Threshold functions.

B. Suggestions for Further Work We felt it impossible (as apparently did out literature sources) to attempt the evaluation of analog models without some traditional base in theory. It is difficult to accept the suggestion of immobility of a few natural examples without knowing "whyi" Therefore, our results are def initely a hybrid of theoretical and analog reasoning and are likely in need of further analog input and testing. The suggestions for further work, given by each individual author, are presented in the following paragraphs. 
Kresan feels that the following areas of work wonld be of particular importance.

Other Analogs:

1. Review of sedimentary basins especially in petroleum literature was Darely touched in our study, Further review would provide considerable information on the geochemistry and porosity/permeadility of sedimentary rucks and characteristics of fluids within these rocks. (Material referenced from Hanor (1979), in Fig. 24, shows temperature-related salinity functions.)

2. A geothermal springs analog built on a comparison of metal bearing and non-metal bearing geothermal waters could provide a more detinite feel for metal modilities (as summarized by Tables 13-17).

3. Replacement deposits, i.e., behavior of metal-bearing solutions as they react with certain minerals to precipitate ore have not been dealt with significantly in this report.

4. Stability and characteristics of alteration products over different temiperature and pressure conditions should be studied. This could yield information on the chenical and physical properties of alteration products formed beforr or during ore deposition which may have influenced deposition. Alteration reactions can significantly influence $\mathrm{pH}$, Eh and cation/anion concentrations, as wall as permeabilities.

$\because$ ispts to Explore:

$i$. nssume a potential for the migration of aqueous solutiuns to predict -inimizing the modility of constituents using the natural :raracteristics of a sequence of rock strata. 


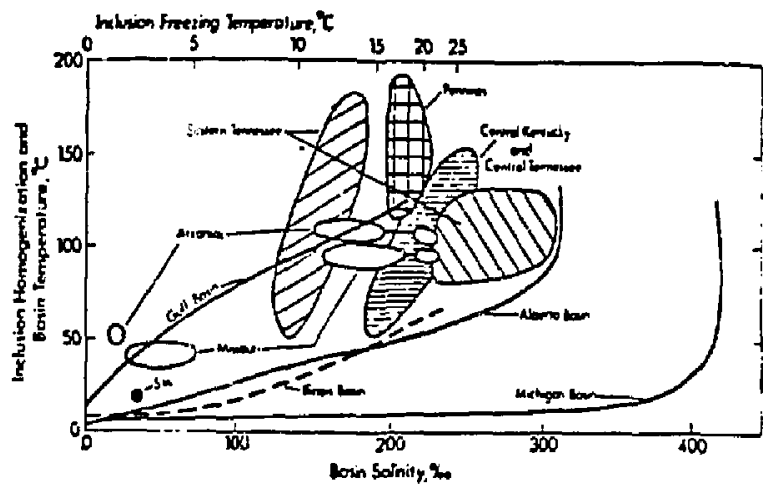

fIG. 24. Temperature-salinity relations in ore-forming fluids from Mississippi Valley type districts (patterned areas), as deduced fron fluid inclusion data, and temperature-salinity relations for waters in the Illinois, Michigan, Alberta, and Mississippi Gulf basins. S.H. marks the position of surface seawater. (From Hanor, 1979) 
TABLE 13. Estimated compositions (weight per cent) of three samples of sulfide-rich scale from pipes discharging Salton Sea brines at well No. 1 IIO.

\begin{tabular}{|c|c|c|c|}
\hline & $\begin{array}{c}W-769 \\
\left(220 \pm 30^{\circ} \mathrm{C}\right)\end{array}$ & $\begin{array}{c}W-767 \\
\left(170^{W} \pm 30^{\circ} \mathrm{C}\right)\end{array}$ & $\begin{array}{c}W-768 \\
\left(130 \pm 20^{\circ} \mathrm{C}\right)\end{array}$ \\
\hline $\begin{array}{l}\mathrm{Si} \\
\mathrm{Cu} \\
\mathrm{Fe} \\
\mathrm{Ag} \\
\mathrm{AS} \\
\mathrm{Sb} \\
\mathrm{Bi} \\
\mathrm{Mn} \\
\mathrm{Co} \\
\mathrm{Al} \\
\mathrm{Ga} \\
\mathrm{Yb} \\
\mathrm{Be} \\
\mathrm{Mg} \\
\mathrm{Ca} \\
\mathrm{Sr} \\
\mathrm{Ba} \\
\mathrm{B} \\
\mathrm{Pb} \\
\mathrm{Sn} \\
\mathrm{Na} \\
\mathrm{K} \\
\mathrm{Ti}\end{array}$ & \begin{tabular}{l}
\multicolumn{1}{c}{$M$} \\
\multicolumn{1}{c}{$M$} \\
5.0 \\
7.0 \\
0.18 \\
0.72 \\
0.11 \\
0.055 \\
0.0050 \\
3. \\
0.0016 \\
0.0002 \\
0.0036 \\
0.014 \\
0.55 \\
0.008 \\
0.014 \\
0.019 \\
0.012 \\
0.002 \\
1.0 \\
1.5 \\
0.0007
\end{tabular} & \begin{tabular}{l}
\multicolumn{1}{l}{11} \\
$M$ \\
7.0 \\
1.3 \\
0.10 \\
0.17 \\
0.004 \\
0.42 \\
0.01004 \\
1.0 \\
0.016 \\
0.0002 \\
0.046 \\
0.0085 \\
0.60 \\
0.003 \\
0.020 \\
0.11 \\
0.011 \\
0.002 \\
1. \\
1. \\
0.0015
\end{tabular} & \begin{tabular}{l}
\multicolumn{1}{l}{1} \\
$M$ \\
6.0 \\
2.8 \\
0.10 \\
0.25 \\
0.009 \\
0.34 \\
0.0006 \\
1.4 \\
0.012 \\
0.0002 \\
0.037 \\
0.0080 \\
0.55 \\
0.003 \\
0.0090 \\
0.080 \\
0.007 \\
0.002 \\
1. \\
1.5 \\
0.0007
\end{tabular} \\
\hline
\end{tabular}

$M=$ major constituent.

(In Stanton, 1972) 
TABLE 14. Quantitative $x$-ray fluorescence analyses

(weight per cent) and mineralogical assemblages

of sulfide-rich scale from No. I IID well, Salton Sea geothermal area.

\begin{tabular}{|c|c|c|c|c|c|c|c|c|}
\hline $\begin{array}{l}\text { Sanple } \\
\text { No. }+\end{array}$ & Temp., & $\mathrm{Cu}$ & $\mathrm{Ag}$ & $\mathrm{Fe}$ & As & Sb & $S$ & $\begin{array}{l}\text { Mineral } \\
\text { content }\end{array}$ \\
\hline $\begin{array}{ll}W-769 & (1) \\
W-769 & (2)\end{array}$ & $\begin{array}{l}220 \pm 30 \\
220 \pm 30\end{array}$ & $\begin{array}{l}10.0 \\
43.6\end{array}$ & $\begin{array}{l}1.2 \\
5.8\end{array}$ & $\begin{array}{l}3.8 \\
7.1\end{array}$ & $\begin{array}{l}0.23 \\
0.15\end{array}$ & $\begin{array}{l}1.05 \\
0.69\end{array}$ & $\begin{array}{r}6.6 \\
22.5\end{array}$ & $\begin{array}{l}\text { bn, } c p, A g \\
\text { bn,cp,ccII, } \\
\text { asp,Ag }\end{array}$ \\
\hline $\begin{array}{l}W-767(1) \\
W-767(2) \\
W-767(3) \\
W-768(1) \\
W-768(2) \\
W-768(3) \\
W-768(4) \\
W-768(5) \\
W-768(6)\end{array}$ & $\begin{array}{l}170 \pm 30 \\
170 \mp 30 \\
170 \mp 30 \\
130 \mp 20 \\
130 \mp 20 \\
130 \mp 25 \\
130 \mp 20 \\
130 \mp 20 \\
130 \mp 20\end{array}$ & $\begin{array}{l}14.0 \\
27.5 \\
23.6 \\
10.1 \\
13.4 \\
19.2 \\
12.4 \\
11.5 \\
28.2\end{array}$ & $\begin{array}{l}1.2 \\
3.1 \\
1.0 \\
1.0 \\
1.2 \\
1.6 \\
1.6 \\
2.1 \\
3.4\end{array}$ & $\begin{array}{r}15.7 \\
8.6 \\
10.6 \\
25.4 \\
18.8 \\
11.3 \\
14.0 \\
12.0 \\
9.8\end{array}$ & $\begin{array}{l}0.20 \\
0.13 \\
0.13 \\
0.30 \\
0.23 \\
0.15 \\
0.15 \\
0.14 \\
0.11\end{array}$ & $\begin{array}{l}0.52 \\
0.66 \\
0.57 \\
0.55 \\
0.53 \\
0.56 \\
0.53 \\
0.45 \\
0.55\end{array}$ & $\begin{array}{r}10.2 \\
13.4 \\
12.8 \\
9.9 \\
10.8 \\
12.2 \\
10.9 \\
11.6 \\
14.2\end{array}$ & $\begin{array}{l}\text { dg, py } \\
\text { bn,ccll, Ag } \\
\text { dg,bn } \\
\text { dg,trace td } \\
\text { dg,trace td } \\
\text { dg,bn, py } \\
\text { dg,bn } \\
\text { dg,strm } \\
\text { bn,cp,ccII, } \\
\text { strm,Ag }\end{array}$ \\
\hline
\end{tabular}

$t$ Individual bands in the scale are indicated by numbers in parentheses, band 1 being the first band deposited in each case. Mineralogical abbreviations: asp=arsenopyrite; bn=bornite; cclI=dense Cu2S;

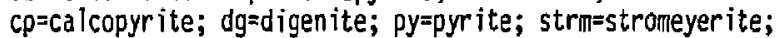
td=tetrahedrite.

(In Stanton, 1972) 
TAULE 13. Concentrations nt Miruar Elements in Wacers From Geotherinal wells and Springs (ppm).

\begin{tabular}{|c|c|c|c|c|c|c|c|c|c|c|c|c|}
\hline & Hn & Fe & Ni & Cu & Pb & $\ln$ & cd & $A_{9}$ & Au & As & so & \\
\hline \multirow{2}{*}{ 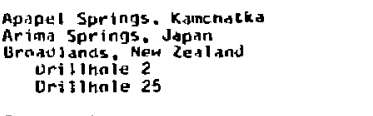 } & 61 & 18.7 & 0.015 & $\begin{array}{l}0.002 \\
0.1\end{array}$ & $\begin{array}{l}0.025 \\
0.4\end{array}$ & 0.005 & & & & 3 & $0.15-0.45$ & \multirow{4}{*}{ 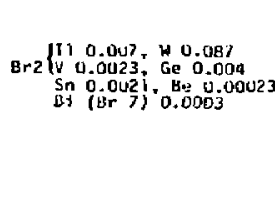 } \\
\hline & 0.0133 & $\begin{array}{l}0.36 \\
0.36\end{array}$ & $\begin{array}{l}0.0002 \\
0.00005\end{array}$ & $\begin{array}{l}0.0009 \\
0.0013\end{array}$ & $\begin{array}{l}0.0413 \\
0.0055\end{array}$ & $\begin{array}{l}0.006 \\
0.0006\end{array}$ & $\begin{array}{l}\text { 0.000401 } \\
0.00002\end{array}$ & $\begin{array}{l}0.0047 \\
0.00025\end{array}$ & 0.00004 & 5.7 & 0.2 & \\
\hline \multirow{2}{*}{ 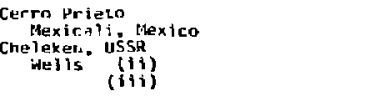 } & 0.64 & 0.2 & 0.002 & 0.005 & 0.0046 & 0.006 & & \multirow[t]{2}{*}{0.049} & \multirow[t]{2}{*}{0.004} & \multirow[t]{2}{*}{2} & \multirow[t]{2}{*}{0.4} & \\
\hline & 46.5 & $\begin{array}{r}14.0 \\
4.2\end{array}$ & D. 33 & $\begin{array}{l}3.41 \\
0.90\end{array}$ & $\begin{array}{l}9.20 \\
3.60\end{array}$ & $\begin{array}{l}3.06 \\
0.19\end{array}$ & $\begin{array}{l}1.06 \\
0.00\end{array}$ & & & & & \\
\hline Geystir, Iceland & & 0.0125 & 0.001 & & & 0.002 & & & & & & 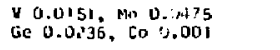 \\
\hline \multirow{2}{*}{ 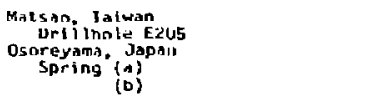 } & 42 & 220 & & 0.05 & $0.6 \sim 0.9$ & 13 & & & & 3.6 & & 412.3 \\
\hline & $\begin{array}{l}1.2 \\
5.4\end{array}$ & $\begin{array}{l}0.02 \\
21.1\end{array}$ & & & $\begin{array}{l}0.01 \\
0.01\end{array}$ & & & & & $\begin{array}{l}39.5 \\
0.04\end{array}$ & & $\begin{array}{l}\text { in } 0.7 \\
\text { A) } 24.2\end{array}$ \\
\hline \multirow{2}{*}{ 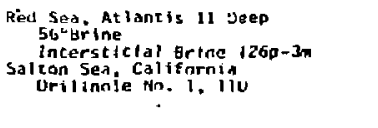 } & $\begin{aligned} \forall 2 \\
134\end{aligned}$ & $\begin{array}{l}86 \\
83\end{array}$ & & $\begin{array}{l}0.25 \\
1.5\end{array}$ & $\begin{array}{l}0.63 \\
0.3\end{array}$ & $\frac{0.54}{7.1}$ & & 0.04 & & & & Lin 0.16, \\
\hline & 1400 & 2290 & & 8 & 102 & 540 & 2.0 & 1.4 & 0.0 & 12 & 0.4 & 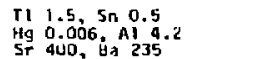 \\
\hline \multirow{2}{*}{$\begin{array}{l}\text { Tamagawa, Japan } \\
\text { Uzon, Kanchatka } \\
\text { Siring in Central Thermal Areas } \\
\text { Hairekes, New Zealand (average } \\
\text { nf several drillmales) }\end{array}$} & 4.2 & 105 & & 0.01 & 7.0 & 2.8 & & & & & & \multirow{2}{*}{ 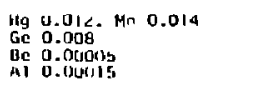 } \\
\hline & 0.0007 & 0.012 & 0.001 & 0.0019 & 0.0045 & 0.0422 & $0.00 u 5 b$ & 0.015 & & 4.7 & 0.1 & \\
\hline
\end{tabular}

(After Barnes, 1979) 
TABLE 16. Examples of geothermal areas explored by orfiling.

\begin{tabular}{|c|c|c|c|c|c|c|}
\hline Ared & Rock Types & $\begin{array}{c}\max \\
\text { drimed } \\
\text { depth } \\
(\mathrm{m})\end{array}$ & $\begin{array}{l}\text { Max. } \\
\text { temp. } \\
(\cdot c)\end{array}$ & $\begin{array}{l}\text { Main solutes } \\
\text { (total dissolved } \\
\text { solids, } 9 / \mathrm{kg}, \\
\text { surface sample) }\end{array}$ & $\begin{array}{l}\text { Water } \\
\text { pH } \\
\text { (surfare. } \\
\text { cold) }\end{array}$ & $\begin{array}{l}\text { Main gases } \\
\text { present }\end{array}$ \\
\hline Reyk javik. Iceland & Tertiary basalt & 2200 & 146 & $\mathrm{Na}^{+}, \mathrm{Cl}^{-}, \mathrm{HCO}_{3}^{-}(0.9)$ & a.6 & $\mathrm{N}_{2}$ \\
\hline Reykjanes. Iceland & Quaternary and Recent basalt & 1750 & 290 & $\mathrm{Na}^{+}, \mathrm{Cl}^{-}, \mathrm{Ca}^{2+}(40)$ & 5.8 & $\mathrm{CO}_{2}, \mathrm{H}_{2}$ \\
\hline $\begin{array}{l}\text { Pauzhetsk, Kamchatka, } \\
\text { U.S.S.R. }\end{array}$ & Quaternary dacite, andesite & 800 & 190 & ${ }_{(3.0)}{ }^{+}, \mathrm{Ca}^{2+}, \mathrm{Cl}^{-}, \mathrm{SO}_{4}{ }^{2-}$ & B.9 & $\mathrm{CO}_{2}, \mathrm{H}_{2} \mathrm{~S}$ \\
\hline El Tatto, chile & $\begin{array}{l}\text { Quaternary and Tertiary rhyolite, } \\
\text { andesite; Mesozoic sediments }\end{array}$ & 600 & 260 & $\mathrm{Na}^{+}, \mathrm{Cl}^{-}(15)$ & 7.0 & $\mathrm{CO}_{2} \cdot \mathrm{N}_{2}, \mathrm{H}_{2} \mathrm{~S}$ \\
\hline Yellowstone Park, U.S.A. & quaternary rhyolite & 330 & 240 & $\mathrm{Na}^{+}, \mathrm{Cl}^{-}, \mathrm{HCO}_{3}^{-}(1.7)$ & 8.8 & $\mathrm{CO}_{2} \times \mathrm{H}_{2} \mathrm{~S}$ \\
\hline Salton Sea, California & $\begin{array}{l}\text { Tertfary sediments (quarternary } \\
\text { rhyolite) }\end{array}$ & 2470 & 360 & $\mathrm{Ha}^{+}, \mathrm{Ca}^{2+}, \mathrm{K}^{+}, \mathrm{Cl}^{-}(350)$ & 5.5 & $\mathrm{CO}_{2}, \mathrm{CH}_{4}, \mathrm{H}_{2} \mathrm{~S}$ \\
\hline Mexicalf, B.C., Mexico & $\begin{array}{l}\text { Sediments; quaternary basalts. } \\
\text { granite }\end{array}$ & 2600 & 370 & $\mathrm{Na}^{+}, \mathrm{CI}^{-}, \mathrm{K}^{+}(17)$ & 5.5 & $\mathrm{CO}_{2}, \mathrm{H}_{2} \mathrm{~S}$ \\
\hline Ngawha, New Zealand & Cretaceous sediments (basalt) & 600 & 235 & $\mathrm{~B}, \mathrm{Cl}^{-}, \mathrm{Ha}^{+}, \mathrm{HCO}_{3}^{-}(\mathrm{B})$ & 7.5 & $\mathrm{CO}_{2}, \mathrm{H}_{2} \mathrm{~S}^{\mathrm{NH}} 3$ \\
\hline Kizildere, Turkey & $\begin{array}{l}\text { Tertiary sandstones, } 1 \text { imestones: } \\
\text { schist. marble }\end{array}$ & 1000 & 220 & 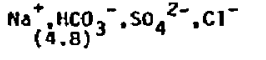 & 9.0 & $\mathrm{CO}_{2} \cdot \mathrm{H}_{2} 5$ \\
\hline Matsuk awa. Japan & $\begin{array}{l}\text { Quaternary and Tertiary andesite, } \\
\text { dacite }\end{array}$ & 1200 & 280 & $\mathrm{Na}^{+}, \mathrm{So}_{4}^{2-}, \mathrm{Fe}^{2+}(1-4)$ & $3-6$ & $\mathrm{CO}_{2}, \mathrm{H}_{2} \mathrm{~S}$ \\
\hline Carderella, Italy & $\begin{array}{l}\text { Mesazoic and Tertiary elays, lime- } \\
\text { stone, anhydrite; Permian shist }\end{array}$ & 1600 & 260 & Steam only & & $\begin{array}{l}\mathrm{CO}_{2}, \mathrm{H}_{2} \mathrm{~S} \\
\mathrm{H}_{3}, \mathrm{BO}_{3}, \mathrm{NH}_{3}\end{array}$ \\
\hline
\end{tabular}

(After Barnes, 1979) 
TABLE 17. Estimated composition of dissolved matter (in ppmi) of brines produced from two bores in the Salton Sea area, California.

\begin{tabular}{|c|c|c|}
\hline Constituent & Bore No. I IID & Bore No. 2 IIO \\
\hline Sodium & 50,400 & 53,000 \\
\hline Potassium & 17,500 & 16,500 \\
\hline Lithium & 215 & 210 \\
\hline Rubidium & 137 & 70 \\
\hline Cesium & 16 & 20 \\
\hline Ammonia $\left(\mathrm{NH}_{4}\right)$ & 409 & \\
\hline Calciuin & 28,000 & 27,800 \\
\hline Magnesium & 54 & 10 \\
\hline Barium & 235 & 250 \\
\hline Strontium & 609 & 440 \\
\hline Cnloride & 155,000 & 155,000 \\
\hline Fluor ine & 15 & Not reported \\
\hline Bromine & 120 & Not reported \\
\hline lodine & 18 & Not reported \\
\hline Sulfate $\left(\mathrm{SO}_{4}\right)$ & 5.4 & Total sulfur $=30$ \\
\hline Sulfide sulfur & 16 & -- \\
\hline Boron & 390 & 390 \\
\hline Iron & 2,090 & 2,000 \\
\hline Manganese & 1,560 & 1,370 \\
\hline Silver & 0.8 & 2 \\
\hline Copper & 8 & 3 \\
\hline Lead & 84 & 80 \\
\hline Zinc & 790 & 500 \\
\hline Arsenic & 12 & Not reported \\
\hline Ant imony & 0.4 & Not reported \\
\hline $\mathrm{CO}_{2}$ as $\mathrm{HCO}_{3}$ & 150 & 690 \\
\hline Silica & 400 & 400 \\
\hline Total reported & 258,360 & 258,765 \\
\hline
\end{tabular}

(From Stanton, 1972) 
2. Solutions evolve as they move through wall rock. Any model dealing with potential modility/transport of radionuclides must incorporate potential changes in the solution during flow.

$\therefore$, cs from wachter regarding further work:

I. Purely analog data may be collected fram diverse sources to test the conclusions regarding $\mathrm{Eh}, \mathrm{pH}, \mathrm{CO}_{2}$, etc. effects as opposed to gross physical/hydrological effects.

Uranium exploration data apparently show some randomness in results, often with low uranium concentrations even in oxidizing uraniuiti systems.

Table 18 shows one of a series of coal-waste materials tested under known Eh, pH conditions. Actinide/lanthanide mobilities are negligible even though present in the test material in moderate concentrations. Tables 19 and 20 further illustrate these test results, indicating significant mobilities of other toxins.

Tables 21 through 24 show the incidents of certain metallic toxins in about 500 wells tested in Arizona.

2. The m-factors approach should be restructured to ref lect more easily obtained information. The m-factors shovid be based on semi-quantitative definition of geologic/geochemical factors or limits imposed by analog models.

3. Drillers' experience, when integrated for a given rock-type in a given area, may yield interesting depth-analog data. waltz and Decker (1981) indicate in the Johnson Drilling Journal that fracture permeability (especially for all except near-vertical fractures) decreases markedly at depths as shallow as 400 feet in the Colorado Front Range Granite. 
Purely analog work, the collection and interpretation of the type of data illustrated here, would as (suggested by the samples in Tabies ia-24) apparently be rewarding and further test the conclusions of this report. 
TABLE 18. Chemical Composition of Lurgi Ash and Slurry Supernatant

Solutions of the Ash from an Illinois No. 6 Coal at severdl ph's,

\begin{tabular}{|c|c|c|c|c|c|c|c|c|c|}
\hline \multirow[b]{3}{*}{ Constituents } & \multirow[b]{3}{*}{$\begin{array}{c}\text { Solid Ash } \\
(\mathrm{mg} / \mathrm{kg})\end{array}$} & \multicolumn{8}{|c|}{ Chemical composition of $10 \%$ slurry supernatant } \\
\hline & & \multicolumn{4}{|c|}{$\begin{array}{c}\text { Air } \\
(\mathrm{n} g / L)\end{array}$} & \multicolumn{4}{|c|}{$\begin{array}{l}\text { Argon } \\
\text { (mg/L) }\end{array}$} \\
\hline & & $\begin{array}{l}\mathrm{pH} \\
7.55 *\end{array}$ & 5.10 & $\begin{array}{l}\text { PH } \\
3.82\end{array}$ & $\begin{array}{c}\mathrm{pH} \\
2.68\end{array}$ & $\begin{array}{l}\text { PH } \\
8.82 *\end{array}$ & $\begin{array}{l}\mathrm{pH} \\
7.20\end{array}$ & phi & $\begin{array}{c}\mathrm{pH} \\
3.79\end{array}$ \\
\hline Ag & $\$ .4$ & - & - & - & - & - & - & - & - \\
\hline Al & 108,121 & $\$ .3$ & 2 & 14 & 132 & 0.3 & $<0.3$ & 0.3 & 92 \\
\hline Av & $<.001$ & - & - & - & - & - &. & - & - \\
\hline As & 3 & $<1,0$ & 1.0 & 41.0 & $<1.0$ & $<1.0$ & 4.0 & $<1.0$ & 4.0 \\
\hline B & 355 & 4.0 & 4.5 & 4.5 & 5.5 & 4.5 & 3.0 & 4.5 & 8.0 \\
\hline $8 a$ & 950 & $<1,0$ & $<1.0$ & $<1.0$ & $<1.0$ & $<1.0$ & $<1.0$ & $<1.0$ & $<1.0$ \\
\hline $8 \mathrm{e}$ & 12 & $<.02$ & $<.02$ & .01 & .03 & $<.02$ & $<.02$ & $c .02$ & .01 \\
\hline$B r$ & $<1.0$ & - & - & - & - & - & - & - & - \\
\hline $\mathrm{Ca}$ & 16,652 & 290 & 480 & 400 & 570 & 440 & 370 & 430 & 500 \\
\hline Cd & $<.6$ & .02 & .03 & .03 & .06 & .01 & $<.03$ & .02 & .05 \\
\hline $\mathrm{Ce}$ & 140 & - & - & - & $=$ & - & - & - & - \\
\hline $\mathrm{Cl}$ & 100 & 25 & $<25$ & 25 & 25 & $<25$ & $<25$ & $<25$ & $<25$ \\
\hline cont & - & 2 & 2 & 2 & 81 & 2 & 2 & 16 & 140 \\
\hline MCE+ & - & 28 & 28 & 0 & 23 & 10 & 3 & 6 & 4 \\
\hline$C r$ & 212 & $<.02$ & .02 & .05 & .12 & .01 & .01 & .06 & .16 \\
\hline$C_{0}$ & 34 & $<.05$ & .05 & .08 & .19 & $<.05$ & $<.05$ & 6.05 & .17 \\
\hline $\mathrm{Cu}$ & 57 & .01 & .02 & .13 & .73 & .01 & .05 & .01 & .05 \\
\hline Cs & 11 & - & - & $\cdot$ & $=$ & - & - & $\cdot$ & - \\
\hline Eu & 1.9 & - & 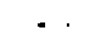 & - & - & - & - &. & \\
\hline $\mathrm{F}$ & e10 & .31 & .30 & .09 & .04 & .51 & .34 & .16 & .02 \\
\hline $\mathrm{Fe}_{\text {total }}$ & 143,780 & .06 & .19 & .24 & 560 & .06 & 11 & 101 & 880 \\
\hline $\mathrm{Fe}^{+2}$ & - & .03 & .11 & .10 & 533 & .13 & .05 & 110 & 864 \\
\hline Ga & 26 & - & - & - & - & - & - & - & - \\
\hline Ge & 7.0 & $=$ & - & - & - & - & - & - & - \\
\hline$H f$ & 6.1 & - & - & - & - & - & - & - & - \\
\hline $\mathrm{Hg}$ & .05 & $<.0002$ & $<.0002$ & .0002 & $<.0002$ & $<.0002$ & $<.0002$ & $<.0002$ & $<, 0002$ \\
\hline 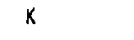 & 14,611 & 42 & 49 & 51 & 26 & 39 & 43 & 48 & 61 \\
\hline La & 47 & - & - & - & - & - & - & • & - \\
\hline Li & 42 & 1.8 & 1.9 & 2.0 & 2.0 & 1.6 & 1.8 & 1.9 & 2.1 \\
\hline Ly & 1.5 & • & - & - & - & - & - & - & - \\
\hline $\mathrm{Mg}$ & 3,739 & 10.5 & 14 & 15 & 22 & 9.5 & 11 & 13.5 & 23 \\
\hline
\end{tabular}


Chemical composition of los slurry supernatant

\begin{tabular}{|c|c|c|c|c|c|c|c|c|c|}
\hline \multirow[b]{3}{*}{ Constituents } & \multirow[b]{3}{*}{$\begin{array}{c}\text { Solid Ash } \\
(\mathrm{mg} / \mathrm{kg})\end{array}$} & \\
\hline & & \multicolumn{4}{|c|}{ Air } & \multicolumn{4}{|c|}{$\begin{array}{l}\text { Argon } \\
(\operatorname{mg} / L)\end{array}$} \\
\hline & & $\begin{array}{l}\mathrm{pH} \\
7.55 *\end{array}$ & $\begin{array}{l}\text { pH } \\
5.10\end{array}$ & $\begin{array}{l}\text { pH } \\
3.82\end{array}$ & $\begin{array}{l}\mathrm{pH} \\
2.68\end{array}$ & $8.82^{\mathrm{pH}}$ & 7.20 & 5.35 & 3.79 \\
\hline$M_{n}$ & 1,859 & .45 & 1.94 & 2.7 & 3.8 & .11 & .90 & 2.3 & 3.7 \\
\hline$M_{0}$ & 30 & $<.03$ & $<.03$ & $c .03$ & $<.03$ & $<.03$ & $<.03$ & 4.03 & 5,03 \\
\hline $\mathrm{Na}$ & 1,929 & 34 & 37 & 38 & 40 & 32 & 37 & 37 & 40 \\
\hline $\mathrm{NHH}_{4}$ & - & 17 & 8 & 12 & 11 & 10 & 10 & 10 & 17 \\
\hline $\mathrm{Ni}^{4}$ & 89 & .03 & .13 & .23 & .50 & 8.07 & .04 & .14 & .42 \\
\hline Po & 45 & .1 & .1 & .1 & .2 & .1 & .1 & .1 & .2 \\
\hline$p$ & 87 & - & - & - & - & - & - & - & - \\
\hline $\mathrm{PO}_{4}$ & - & $<.01$ & $<.01$ & $<.01$ & $<.01$ & $<.01$ & 4,01 & $<.01$ & $<, 01$ \\
\hline $\mathrm{Rb}^{-4}$ & 162 & $\cdot$ & $\cdot$ & - & - & - & $\cdot$ & - & - \\
\hline $5_{\text {Total }}$ & 6,100 & - & - & - & - & - & - & - & $\cdot$ \\
\hline $5^{-2}$ & 1,500 & $<.2$ & $<.2$ & $<.2$ & $<.2$ & $c .2$ & $<.2$ & 6.2 & $\bullet .2$ \\
\hline $\mathrm{SO}_{4}$ & 8,100 & 820 & 943 & 808 & 338 & 730 & 735 & 700 & 710 \\
\hline So & 4.2 & .2 & .3 & .3 & .6 & .3 & .3 & .3 & .5 \\
\hline Sc & २9 & - & - & - & $\cdot$ & - & - & - & $=$ \\
\hline $\mathrm{Se}_{\mathrm{e}}$ & 8 & $\$ .1$ & $<.1$ & 8.1 & 4.1 & $<.1$ & $<.1$ & $<.1$ & $<+1$ \\
\hline $5 i$ & 29,946 & 5 & 29 & 60 & 130 & 4 & 9 & 27 & 120 \\
\hline Sin & 8.21 & - & - & - & - & - & - & - & - \\
\hline$s_{n}$ & - & $<1.0$ & $<1.0$ & $<1.0$ & $<1.0$ & $<1.0$ & $<i .0$ & $<1.0$ & Cl.0 \\
\hline$S_{r}$ & 370 & 1.8 & 1.9 & 2.1 & 2.9 & 1.5 & 1.7 & 1.9 & 2.6 \\
\hline$T_{3}$ & 1.1 & - & - & - & - & - & - & - & - \\
\hline Te & - & 0.5 & 0.5 & 0.5 & $८ 0.5$ & $\$ 0.5$ & 0.5 & 0.5 & 0.5 \\
\hline $\mathrm{Th}$ & 21 & - & • & - & - & - & - & - & - \\
\hline $\mathrm{Ti}$ & 6,295 & $\$ .5$ & 0.5 & $\varangle .5$ & 0.5 & 40.5 & 0.5 & 4.5 & 0.5 \\
\hline$\pi$ & 4.6 & 0.4 & 80.4 & $\varangle .4$ & 0.4 & 40.4 & $\$ .4$ & 8.4 & 80.4 \\
\hline$v$ & 17 & - & - & - & - & - & - & - & - \\
\hline$v$ & 184 & . & - & - & - & . & - & - & - \\
\hline$H$ & 1.5 & - & - & - & - & - & - & - & - \\
\hline$Y_{b}$ & 2.9 & - & - & - & - & - & - & - & - \\
\hline $2 n$ & 900 & .12 & 5.5 & 12 & 17 & .01 & .11 & 6.5 & 20 \\
\hline$z r$ & 170 & - & - & - & - & - & - & 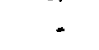 & - \\
\hline Ec $($ mmhos $/ \mathrm{cm})$ & - & 1.17 & 1.50 & 1.95 & 5.60 & 1.20 & 1.39 & 1.80 & 5.20 \\
\hline In (alastrode ny) & - & +223 & +246 & +407 & +349 & +109 & +161 & +102 & +243 \\
\hline
\end{tabular}

-Mt:isezl or of supernatant.

Ziesizal oxygen demand.

*a: aplene chloride extractable organics.

'Frop îriffen et al., (980) 


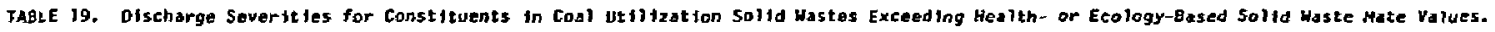

\begin{tabular}{|c|c|c|c|c|c|c|c|c|c|c|c|c|c|}
\hline $\begin{array}{l}\text { Param- } \\
\text { eter }\end{array}$ & $\begin{array}{l}\text { Res/th } \\
(\mathrm{mg} / \mathrm{kg})\end{array}$ & $\bar{c}$ & $\begin{array}{l}\text { Lurg! } \\
\text { Mo. } 5\end{array}$ & $\begin{array}{l}\text { Lurg! } \\
\text { Ko. } 6\end{array}$ & $\begin{array}{l}\text { Lurg: } \\
\text { Rose: } \\
\text { butd }\end{array}$ & H-Cos1 & SRC & $\begin{array}{l}\text { Fyp } \\
\text { dosh }\end{array}$ & $\begin{array}{l}\text { 8ottom } \\
\text { ssh } \\
\text { (sheg) }\end{array}$ & $\begin{array}{l}\text { Hign- } \\
\text { temp. } \\
\text { char }\end{array}$ & $\begin{array}{l}\text { Hedium- } \\
\text { temp. } \\
\text { chat }\end{array}$ & $\begin{array}{l}\text { High-S } \\
\text { refuse }\end{array}$ & $\begin{array}{l}\text { Lon-S } \\
\text { refuse }\end{array}$ \\
\hline \multirow{16}{*}{ 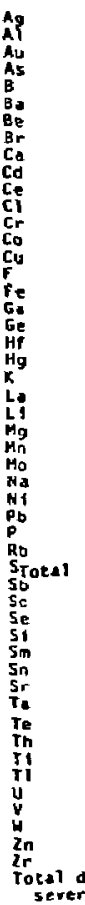 } & \multirow{16}{*}{ 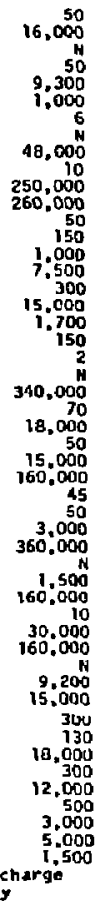 } & \multirow{16}{*}{ 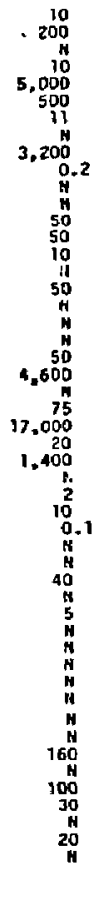 } & 478 & 541 & 506 & 66 & 338 & 368 & 123 & B6 & 68 & 283 & 485 \\
\hline & & & 1 & & 2 & & 7 & 5 & & & & 2 & 1 \\
\hline & & & $\frac{2}{2}$ & $\begin{array}{l}2 \\
2\end{array}$ & 8 & & 2 & 3 & 1 & & & & \\
\hline & & & ? & 5 & $\stackrel{19}{a}$ & $\frac{2}{2}$ & $\begin{array}{l}2 \\
6\end{array}$ & $\stackrel{\text { B }}{9}$ & - lit & $\frac{1}{2}$ & $\frac{2}{2}$ & $\stackrel{9}{7}$ & $?$ \\
\hline & & & $\mathbf{3}$ & 4 & 1 & & 2 & 3 & 2 & & & & 2 \\
\hline & & & 5 & 6 & 5 & 1 & 10 & 14 & 4 & 1 & 1 & 3 & 4 \\
\hline & & & 3,020 & 2,876 & 1,201 & 473 & 2,703 & $2,68 \mathrm{~B}$ & $2.7 \div 5$ & 419 & דונו & 1.723 & 496 \\
\hline & & & 3 & 3 & 1 & & 2 & 5 & 3 & & & 2 & 4 \\
\hline & & & 101 & 93 & 46 & 1 & 8 & 19 & 23 & 4 & $\mathbf{3}$ & 15 & 15 \\
\hline & & & $\begin{array}{r}97 \\
18 \\
2,180\end{array}$ & $\begin{array}{r}44 \\
4 \\
870\end{array}$ & $\frac{2}{4}$ & $\begin{array}{r}10 \\
3 \\
140\end{array}$ & $\begin{array}{r}7 \\
6 \\
10,040\end{array}$ & $\begin{array}{r}80 \\
11 \\
8,730\end{array}$ & $\begin{array}{r}28 \\
2 \\
2860\end{array}$ & $\begin{array}{r}10 \\
1 \\
870\end{array}$ & $\begin{array}{r}6 \\
870\end{array}$ & $\begin{array}{r}24 \\
5 \\
8,290\end{array}$ & $\begin{array}{r}27 \\
5\end{array}$ \\
\hline & & & & & & & & & & & & & \\
\hline & & & B & $\mathbf{a}$ & s & 1 & 4 & 6 & 7 & 1 & 2 & 5 & 9 \\
\hline & & & 40 & 39 & 40 & 6. & 11 & 32 & 28 & 6 & 27 & 29 & 52 \\
\hline & & & 6 & 6 & 1 & 1 & 1 & a & 2 & & & 1 & 1 \\
\hline & & & 75 & 20 & 2 & 4 & & 28 & 3 & 2 & 2 & 15 & 25 \\
\hline & & & 6,054 & 4.531 & 22,805 & 1,033 & 13,152 & 12,020 & 11,155 & 1.463 & 1,100 & 10,412 & 15.1 to \\
\hline
\end{tabular}

Discharge severity - concentrat lon/HATE

(From Eriffen et 1 1.. 1900) 
TABLE 20. Elements with Concentrations Exceeding Recommended water Quality Levels Under the Laboratory Test Conditions.

\begin{tabular}{|c|c|c|c|c|}
\hline \multirow[b]{2}{*}{ Sample } & \multicolumn{4}{|c|}{ Natural pH } \\
\hline & $\mathrm{pH}$ range & Air & Argon & Constituents \\
\hline $\begin{array}{l}\text { Lurgi Ash } \\
\text { (II). } \# \text { Coal) }\end{array}$ & $8.8-2.7$ & 7.6 & 8.8 & $\begin{array}{l}\mathrm{B}, \mathrm{Ca}, \mathrm{Cd}, \mathrm{K}, \mathrm{Hn}, \\
\mathrm{NH}_{4}, \mathrm{PD}, \mathrm{SO}_{4}, \\
\mathrm{So}\end{array}$ \\
\hline $\begin{array}{l}\text { Lurgi Ash } \\
\text { (II). \#5 Coal) }\end{array}$ & $10.9-3.1$ & 8.3 & 10.9 & $\begin{array}{l}\mathrm{B}, \mathrm{Ca}, \mathrm{K}, \mathrm{Mn}, \\
\mathrm{NH}_{4}, \mathrm{~Pb}, \mathrm{SO}_{4},\end{array}$ \\
\hline $\begin{array}{l}\text { Lurgi Ash } \\
\text { (Rosebud Coal } \\
\text { Mont.) }\end{array}$ & $11.1-3.1$ & 8.4 & 11.1 & $\begin{array}{l}\mathrm{B}, \mathrm{Ca}, \mathrm{Cd}, \mathrm{F}, \mathrm{K}, \\
\mathrm{Mo}, \mathrm{NH}_{4}, \mathrm{PD}, \\
\mathrm{SO}_{4}, \mathrm{Sb}\end{array}$ \\
\hline SRC & $10.2-2.9$ & 6.4 & 7.5 & $\begin{array}{l}\mathrm{B}, \mathrm{Ca}, \mathrm{Fe}, \mathrm{Hn}, \\
\mathrm{NH}_{4}, \mathrm{SO}_{4}\end{array}$ \\
\hline H-Coal & $11.3-2.3$ & 8.8 & 11.3 & $\mathrm{~B}, \mathrm{Ca}, \mathrm{NH}_{4}$ \\
\hline Char $\left(1200^{\circ} \mathrm{F}\right)$ & $9.7-2.4$ & 7.2 & 7.6 & $B$ \\
\hline $\operatorname{Char}\left(1800^{\circ} \mathrm{F}\right)$ & $8.1-2.5$ & 8.1 & 7.5 & $\mathrm{~B}, \mathrm{Ca}, \mathrm{Mn}, \mathrm{NH}_{4}$ \\
\hline Low-sulfur gob & $9.2-2.4$ & 9.2 & 9.2 & None \\
\hline High-sulfur gob & $8.9-2.5$ & 7.5 & 7.4 & $\mathrm{~K}, \mathrm{NH}_{4}, \mathrm{SO}_{4}$ \\
\hline STag & $8.8-2.8$ & 3.8 & 5.7 & $\mathrm{NH}_{4}$ \\
\hline Fly ash & $10.0-2.5$ & 4.1 & 4.3 & $\mathrm{~B}, \mathrm{Ca}, \mathrm{SO}_{4}$ \\
\hline
\end{tabular}

(From Griffen et at., 1980) 
TABLE 21. Highest concentration of copper and samples exceeding the U.S. Public Health recommended limit of 1.0 pom for the counties of Arizona.

\begin{tabular}{lccc}
\hline County & Highest Value & \multicolumn{2}{c}{ Samples Exceeding 1.0 pom } \\
& ppm & No. & $\%$ \\
\hline Apache & 0.58 & 0 & 0.0 \\
Cochise & 0.14 & 0 & 0.0 \\
Coconino & 4.36 & 1 & 3.6 \\
Gila & 0.50 & 0 & 0.0 \\
Graham & 0.25 & 0 & 0.0 \\
Greenlee & 0.04 & 0 & 0.0 \\
Maricopa & 0.46 & 0 & 0.0 \\
Mohave & 2.63 & 1 & 2.9 \\
Navajo & 0.43 & 0 & 0.0 \\
Pima & 22.60 & 4 & 2.1 \\
Pinal & 4.26 & 1 & 0.7 \\
Santa Cruz & 0.01 & 0 & 0.0 \\
Yavapai & 1.23 & 1 & 9.1 \\
Yuma & 0.10 & 0 & 0.0 \\
Ali Counties & 22.60 & 8 & 1.2 \\
& & & \\
\hline
\end{tabular}

TABLE 22. Highest concentration of zinc and samples exceeding the U.S. Public Health recommended limit of $5.0 \mathrm{ppm}$ for the counties of Arizona.

\begin{tabular}{lccc}
\hline County & Highest Value & Samples Exceeding 5.0 ppm \\
& ppm & No. & $\%$ \\
\hline Apache & 1.73 & 0 & 0.0 \\
Cochise & 2.78 & 0 & 0.0 \\
Coconino & 1.91 & 0 & 0.0 \\
Gila & 0.57 & 0 & 0.0 \\
Graham & 0.33 & 0 & 0.0 \\
Greenlee & 0.03 & 0 & 0.0 \\
Maricopa & 0.68 & 0 & 0.0 \\
Mohave & 0.864 & 0 & 0.0 \\
Navajo & 4.54 & 0 & 0.0 \\
Pima & 3.0 & 0 & 0.0 \\
Pinal & 15.14 & 2 & 1.5 \\
Santa Cruz & 0.01 & 0 & 0.0 \\
Yavapai & 0.34 & 0 & 0.0 \\
Yuma & 0.28 & 0 & 0.0 \\
All Counties & 15.14 & 2 & 0.3 \\
\hline
\end{tabular}

(From Dutt and McCreary, 1970) 
TABLE 23. Highest concentration of lead and samples exceeding the U.S. Public Health Service mandatory limit of 0.01 ppon for the counties of Arizona.

\begin{tabular}{lccc}
\hline County & Highest Value & Samples Exceeding $0.01 \mathrm{ppm}$ \\
& ppm & No. & \\
\hline Aoache & 0.088 & 7 & 30.4 \\
Cothise & 0.045 & 0 & 0.0 \\
Coconino & 0.167 & 3 & 10.7 \\
Gila & 0.000 & 0 & 0.0 \\
Grdian & 0.000 & 0 & 0.0 \\
Greenlee & 0.000 & 0 & 0.0 \\
Maricopa & 0.177 & 8 & 11.0 \\
Mohave & 0.029 & 0 & 0.0 \\
Navajo & 0.254 & 2 & 7.4 \\
Pima & 0.518 & 3 & 9.6 \\
Pinal & 0.175 & 0 & 2.2 \\
Santa Cruz & 0.043 & 0 & 0.0 \\
Yavapai & 0.000 & 3 & 0.0 \\
Yuma & 0.113 & 44 & 12.0 \\
All Counties & 0.518 & & 6.5 \\
\hline
\end{tabular}

TABLE 24. Highest concentration of cadmium and samples exceeding the U.S. Public Heatth Service mandatory limit of $0.01 \mathrm{ppm}$ for the counties of Arizona.

\begin{tabular}{lccc}
\hline County & Highest Value & Samples Exceeding 0.01 opm \\
& ppm & No. & \\
\hline Apache & 0.494 & 1 & 4.4 \\
Cochise & 0.003 & 0 & 0.0 \\
Coconino & 0.002 & 0 & 0.0 \\
Gila & 0.000 & 0 & 0.0 \\
Graham & 0.000 & 0 & 0.0 \\
Greenlee & 0.000 & 0 & 0.0 \\
Maricopa & 0.204 & 2 & 2.7 \\
Mohave & 0.000 & 0 & 0.0 \\
Navajo & 0.004 & 0 & 0.0 \\
Pima & 0.080 & 8 & 4.2 \\
Sinal & 0.011 & 1 & 0.7 \\
Santa Cruz & 0.000 & 0 & 0.0 \\
Yavapai & 0.000 & 0 & 0.0 \\
Yuma & 0.004 & 0 & 0.0 \\
All Counties & 0.494 & 12 & 1.8 \\
\hline
\end{tabular}

(From Dutt and McCreary, 1970) 


\section{REFERENCES}

\section{A. Fission Product Behavior}

Allard, B. et a). (1980), "Possible Retention of lodine in the Ground," in Northrup, ed., p. 673-680.

Allard, B. et al. (1979), "Disposal of Radioactive Waste in Granitic Bedrock," in Fried, ed., p. 48-73.

Allen, E. J., (1978), "Criticality Analys is of Aggregation, of Actirides Fron Cormercial Nuclear Waste in Genlogical Storage," JRRL/TM-6458 II.S. O0E August.

Andelman, J. B. and T. ᄃ. Rozzell (1970), "Plutonium in the Water Environment," in Radionuclides in the Enyironment, S. E. Fierling, ed., Am. Chem. Soc., Washington, D.C. p. 118.

Apt, K. E., ed. (1977), "Investigations of the R.:tural Fission Reactor Program," Los Alamos Report No. 7032-PR.

Barney, G. S. (1979), "Variables Affecting Sorption and Transport of Radionuclides in Hanford Subsoils," in McCarthy, ed., p. 435-438.

Barthel, F. H. (1974), "Review of Uranium Occurrences in Permian Sediments in Europe, with Special Reference to !ranium Mineralizations in Permian Sandstone," in IAEA Proc., Athens, May 1974, p. 277-289.

Beall, G. W. and B. Aliard (1980), "Prediction of Sorption Behavior of Aci inides on Geologic Media," in Abstracts, Materials Researcin Society, p. 094 .

Beali: G. W. et al. (1980), "Chemical Reactions in the Bedrock-Groundwater System of Importance for the Sorption of Actinides." in Northrup ed., p. 625-631. 
Beall, G. W. et al. (1979), "Sorption Behavior of Trivalent Actinides and Rare Earths on Clay Minerals," in Fried, ed., p. 201-213.

Bird, G. W. and V. J. Lopata (1980), "Solution Interaction of Nuclear Waste Anions with Selected Geological Materials," in Northrup, ed., p. 419-426.

Bondietti, E. A. and C. W. Francis (1979), "Chemistry of TC-99 and NP-237 in Contact with Unweathered Igneous Rocks," in McCarthy, ed., p. 417-418.

Bredehoeft, J. D. et al. (1978), "Geologic Disposal of High-Level Radioactive Wastes - Earth Science- Perspectives," U.S. Geol. Survey Circular 779.

Breger, I. A. (1974), "The Role of Organic Matter in the Accumulation of Uranium," in IAEA Proc., Athens, May 1974, p. 99-124.

Brookins, D. G. (1980), "Geochemistry of Clay Minerals for Uranium Exploration in the Grants Mineral Belt, New Mexico," AIME Preprint 80-112, $12 \mathrm{p}$.

Brookins, O. G. (1980), "Clay Minerals Suitable for Overpack in Waste Repositories: Evidence from Uranium Deposits," in Northrup, ed., p. $427-435$.

Brookins, D. G. (1979), "Thermodynamic Considerations Underlying the Migration of Radionuclides in Geomedia: Oklo and Other Examples," in McCarthy, ed., p. 355-366.

Brookins, D. G. (1978), "Application of Eh-pH Diagrams to Problems of Retention and/or Migration of Fissiogenic Elements at OKio," in IAEA Natural Fission Reactors Proc., p. 243-265.

Brookins, D. G. (1976), "Uranium Deposits of the Grants, New Mexico Mineral Belt," ERDA/O0E Rept. GJ0-1636-1, Grand Junction, Colo.

Burkholder, H. C. and C. Defigh-Price (1978), "Diffusion of Radionuclide Chains Through an Adsorbing Medium," in Am. Inst. of Chem. Eng. Symp. Series No. 179, Vol. 74. 
Burkholder, H. C. and M. O. Cloninger (1978), "The Reconcentration Phenomenon of Radionuclide Chain Migration," in Am. Inst. of Chem. Eng. Symp. Series No. 179 Vol. 74, p. 83-90.

inipman, N., G. Simpson, H. Rodger, R. Frendberg, and H. Lawroski (1980), "Environmental Effects From Disposal of Defense High Level Radioactive Wastes in a Generic Geologic Repository", in Northrup, ed., p. 813.

Claassen, H. C. (1978), Hydraulic Processes and Radionuclide Distribution in a Cavity and Chimney Produced by the Cannik in Nuclear Explosion, Amchitka Island, Alaska, U.S. GeoI. Survey, Prof. Paper 712-0.

Cohen, B. L. and H. H. Jow (1978), "A Generic Hazard Evaluation of Low-Level Waste Burial Grounds," Nuclear Technology, Vol. 47, p. 387-388.

Cowan, G. A. (1978), "Migration Paths for Ok lo Reactors Products and Applications to the Problem of Geological Storage of Nuclear Wastes, " in IAEA Natural Fission Reactors Proc., p. 693-699.

Cotton, F. A. and G. Wilkinson (1967), Advanced Inorganic Chemistry, John Wiley, N. Y.

Dahl, A. R. and J. L. Hagmaier (1974), "Genesis and Characteristics of the Southern Powder River Bas in Uranium Deposits, Hy. U.S.A.," in IAEA Proc., Atnens, May 1974, p. 201-216.

Dall'Aglio, M. et al. (1974), "Geochemical Factors Controlling the Formation of the Secondary Minerals of Uranium," in IAEA Proc. Athens, May 1974, p. $33-48$.

Dosch, R. G. and A. W. Lynch (1980), "Radionuclide Transport in a Dolomite Aquifer," in Northrup, ed., p. 617-624.

Dosch, R. G. (1979), "Racionuciide Migration Studies Associated with the WIPP Site in S. New Mexico," in MeCarthy, ed., p. 395-398. 
Ouffy, c. J. (1978), "Uranium Solubilities in the Oklo Reactor Zones," in IAEA Natura] Fission Reactors Proc., p. 229-234.

Dyck, W. (1978), "The Mobility and Conclusions of $U$ and Its Decay Products in Temperate Surficial Environments," in Kimberley, ed.

E) Shazy, E. M. et a). (1974), "Origin of U in Oligocene Qatrani Sediments, Western Desert, Arab Republic of Egypt," in IAEA Proc. Athens, May, 1974 p. $467-477$.

Erdal, B. R. et al. (1980), "Parameters Affecting Radionuclide Migration in Geologic Media," in Northrup, ed., p. 609-616.

Erda1, B. R, et al. (1979), "Sorption and Migration of Radionuclides in Geologic Media," in McCartny, ed., p. 423-426.

Erickson, K. L. (1980), "Radionuclide Sorption Studies on Abyssal Red Clays," in Northrup, ed., D. 641-646.

Erickson, K. L. (1979), "Radionucl ide Sorption Studies on Abyssal Red Clays," in fried, ed.

Ermolenko, N. K. (1972), Trace Elements and Colluids in Soils, ind. ed., (Translated fram Russian), Israel Prog. for Scientific Translation and U.S. Dept. of Commerce.

Freeborn, W. et al. (1980), "Shale Rocks as Nuclear Waste Repositories: Hydrothermal Reactions with Glass, Ceramic and Spent Fuel Waste Forms," in Northrup, ed., $p .499-506$.

Fried, S. et a), (1980), "The Radiolytic Oxidation ani Reduction of Plutonium," in Northrup, ed., p. 655-664. 
Fried, S., ed. (1979), Radioactive Waste in Geologic Storage, Am. Chem. Soc. Symp. Series 100, Sept. 1978, Miami Beach, FL.

Fried, S. et al. (1976), "Migration of Actinides in Geologic Formations," in Proc. on Internat. Symp. of Management of Wastes from the LWR Fuel Cycle, July 11-16, 1976, Denver, p. 697-701.

Friedmar, A. M. and S. Fried (1979), "Kinetic Effects in Migration," in Fried, ed., p. 191.199.

Fre'jacques, C. and R. Hidgemann (1979), "Conclusions from Studies of the $0 \mathrm{k} 10$ Natural Reactor," in Proc. on Internat. Symp. of Management of Wastes from the LWR Fuel Cycle, July 11-16, 1976, Denver.

Fritz, P. et al. (1980), "Geochemistry, Origin a. I Age of Groundwater in the Stripa (Sweden) Test Mine," in Northrup, ed., p. 543-552.

Galley, J. E., ed. (1968), "Subsurface Disposal in Geologic Basins - A Study of Reservoir Strata," Am. Assoc. of Petrol Geol. Memoir 10.

Gancarz, A. et al. (1980), "99 $\mathrm{Tc}, \mathrm{Pb}$ and Ru Migration Around the 0k 10 Natural Fission Reactors," in Northrup, ed., p. 601-608.

Griffen, R. A. et al. (1980), "Chemical and Biological Characterization of Leachates from Coal Sol id Wastes, "Illinois inst. of Natural Resources, Env. Geol. Notes, 89, Chainpaign, Ill.

Haire, R. G. and G. W. Beall (1979), "Consequences of Radiation From Sorbed Transplutonium Elements on Clays Selected for Waste Isolation, "in Frier, ed., p. 291-295.

Hinkebein, T. E. and P. F. Hlava (1979), "Interactions of Simulated Waste Radionuclides and Rocks," in McCarthy, ed., p. 419-422.

Hinkebein, T. E. and P. F. Hlava (1978), "Microstructural Interactions of Geologic Media With Waste Radionuclides," Sandia, SAird 78-0108. 
Hoffman, D. C. (1979), "A Field Study of Radionuclide Migration," in Fried, ed., p. 149-166.

I.A.E.A. (1978), Natural Fission Reactors, Proceedings from Dec. 1977, Paris Meeting, Second Int. Conf. on Oklo., Publication TC-119/33.

\section{I.A.E.A. (1977), Site Selection Factors for Repositories of Solid High-Level} and Alpha-Bearing Wastes in Geologic Formations, Technical Reports Series No. 177.

I.A.E.A. (1974), Formation of Uranium Ore Deposits, Proc. of a Symp., Athens, May, 1974.

I.A.E.A. (1y67), Disposal of Radioactive Waste Into the Ground, Proc. of a Symp., May 29-June 2, 1967.

ICRP (1975), "Report of the Task Group on Reference Man," Internatjona] Comission of Radiation Protection, Publication \#23, Pergamon Press, NY.

Jakubick, A. T. (1979), "Analys is of Pu-release Consequences on the Environmental Geochemistry," in McCarthy, ed., p. 427-434.

Janse, A. J. A. (1969), "Gross Brukkaros, A Probable Carbonatite Volcano in the Nama Plateau of SH Africa," Geol. Soc. of Am. Bull., Vol. 80, p. 573-586.

Jayaram, K. M. V. et al. (1974), "A. Study of the Influence of Microflora on the Genesis of Uranium Occurrences of Udaisagas, Udaipur Oistrict, Rajasthan," (India), in IAEA Proc. Athens, May 1974, p. 89-98.

Katayama, N. et al. (1974), "Genesis of Uranium Deposits of the Tono Mine, Japan," in IAEA Proc., Atnens, May 1974, p. 437-452.

Kimberley, M. M., ed. (1978), Short Course in Uranium Oeposits: Their Mineralogy and Origin, Mineralogical Association of Canada, Toronto. 
simberley, M. M. (1978), "Irigin of Stratiform Uranium Deposits in Sandstone, Conglomerate, and Pyroclastic Rock," in Kimberley, ed.

Kocher, D. C. (1979), "A Dynamic Model of the Global Iodine Cycle for the Estimation of Dose to the World Population from Release; of Iodine -129 to the Environment," NUREG/CR-0717, ORNL/NUREG-59.

Komarneni, S, and R. Roy (1980), "Super Overpack: Tailor-made Mixtures of Zeolites and Clays," in Northrup, ed., p. 411-418.

Langford, F. F. (1978), "Origin of Unconformity-Type Pitchblende Deposits in the Athabasca Basin of Saskatchewan," in Kimberley, ed.

Langmuir, D. (1978), "Uranium Solution-Mineral Equilibrium at Low Temperatures with Application to Sedimentary Ore Deposits, "Geochim. Cosmochim. Acta, Vol. 42, 1978, p. 547-569.

Langmuir, D.·(1978), "Uranium Solution-Mineral Equilibria at Low Temperatures with Applications to Sedimentary Ore Deposits," in Kimberley, ed., p. 17-55.

Langmuir, D. (1977), "Jranium Solution - Mineral Equilibria at Low Temperatures with Applications to Sedimentary Ore Deposits, "ERDA/DOE Rept., GJ0-1659-3 (GJBX-54), Grand Junction, Colo.

Lynch, A. H. and R. G. Dosch (1980), "Interaction of Radionuclides with Geomedia From the Nevada Test Site," in Northrup, ed., p. 633-640.

Magne, R. et al. (1974), "Solubilization and Insolubilization of Uranium From Granites by Heterotrophic Bacteria," in IAEA Proc. Athens, May 1974, p. 73-88.

Meyer, G. L. (1976), "Recent Experience with Land Burial of Solid Law-Level Radioactive Waste," in Symp. Proc., March, IAEA/OECD-MEA, Vol. II. 
Miller, L. J. (1958), "The Chemical Environment of Pitchblende, "Geology, Vol. 53, ค. 521 .

Morton, R. D. (1974), "Sandstone-Type Uranium Deposits in the Proterozoic Strata of NW Canada," in IAEA Proc., Athens, May 1974, p. 255-273.

McCarthy, G. J., ed. (1979), Scientific Basis for Nuclear Waste Management, Vol. 1, Plenum Press, NY.

Mcmillan, R. H. (1978), in "Origin of Stratiform Uranium Deposits," Kimberley, ed., p. 199.

NAS (1978), "Geological Criteria for Repositories for High-Level Radioactive Wastes," Panel on Geological Site Criteria, Nat. Acad. Sci., Wash., DC.

Nandet, R. (1978), "Summary of the Data on the Stability and the Re-Mobilization of Uranium and Rare Earths," in IAEA Natural Fission Reactors Proc., p. 643-673.

MEA (1977), "Oojectives, Concepts and Strategies for the Management of Radioactive Waste Arising From Nuclear Power Programmes," Sept. Report by an NEA Group of Experts, Nuclear Energy Agency.

Northrup, C. J. M., Jr., ed. (1980), Scientific Basis for Nuclear Waste Management, Voi. 2, Proc. from Fall, 1979, Internat. Symp. on the Sci. Basis for Nuclear Waste Management, Mat. Res. Soc., Boston, Plenum Press, NY.

Nowak, E. J. (1980), "The Backfill as an Engineered Barrier for Nuclear Waste Management," in Northrup, ed., p. 403-410.

NwTS Program Office (1980), Proceedings of the 1980 Nat. Haste Terminal Storage Program Information Meet ing, Dec., ONWI-212, U.S. DOE.

Ogard, A. et al. (1980), "Are Solubility Limits of Importance to Leaching?" Abst. Mat. Res. Soc., p. 041. 
Pecora, W. T. (1956), "Carbonatites: A Review," Geol. Soc. All. Bull,, vol. 67, p. 1537-1556.

Poston, J. H. (1978), "Measures of Equivalent Hazard of Radionuclides: A Survey," May, Union Carbide Corp./Office of Waste Isolation, DOE.

Poty, B. P. et al. (1974), "Fluid Inclusions in Uranium Ores From Intragranitic leposits in Limousin and Forez, France," in IAEA Proc., Athens, May 1974, P. 569-581.

Register, J. K. et al. (1980), "Clay Mineral-Brine Interactions During Evaporite Oiagenesis: Lanthanide Distribution in WIPP Samples," in Northrup, ed., p. 445-451.

Ricn, R. A., H. D. Holland and U. Petersen (1975), "Vein-Type Uranium Deposits", ERDA/DOE Report, GJO-1640, Grand Junction, Colo.

Rickert, P. G. et al. (1979), "Nuc.ide Migration in Fractured or Porous Rock," in Fried, ed., p. 167-789.

Rimsaite, J. (1978), "Application of Mineralogy to the Study of Multi-State Uranium Mineralization in Remobilized Uranium Deposits, Saskatchewan," in Kimberley, ed., p. 403-430.

Roberts, L. E. J. (1978), "Radioactive Waste, Policy and Perspectives," British Nuc lear Energy Society, Nov, $y$.

Ruffenach, J. C. (1978), "The Natural Reactors of Oklo: Study of Uranium and Rare-Earth Migration in a Core Sample and Its Application to the Dating of the Nuclear Reactions," in IAEA Natural Fission Reactors Proc., p. 441-471.

Shiąo, \$. Y. et al. (1979), "Ion-Exchange Equilibrium Between Montmorillonite and Solutions of Moderate-to-High Ionic Strength, "in Fried, ed., p. 297-324. 
Silbey, D. F. and J. T. Wilband (1977), "Chemical Balance of the Earth's Crust," Geochim. Cosmocnim. Acta, Vol. 41, p. 545.

Silva, R. J, et al. (1979), "Studies of Actinides Sorption on Selected Geologic Materials," in Fried, ed., p. 215-240.

Smitn, C. F.: J. J. Cohen, and T. E. Hckone (1980), "A Hazard Index for Underground Toxic Materiai," UCRL-52889, Lawrence Livermore Laboratory, June 1980.

Smyth, J. R. et al. (1980). "Microautoradiographic Studies of the Sorption of $U$ and An on Natural Rock Samples," Radioactive Waste Management Vol, I, No. 1, p. 13, Harwood Academic Pub., NY.

Stanton, R. L. (1972), Ore Petrology, McGraw-Hi11, NY.

Spitsyn, V. I. and V. D. Balukova (1979), "The Scientific Basis For, and Experience with Underground Storage of Liquid Radioactive Wastes in the IJSSR," in MCCarthy, ed., p. 237-248.

Szalay, A. (1967), "The Role of Humic Acids in the Geocnemistry of Uranium and The ir Possiole Role in the Geochemistry of Other Cations," in Chemistry of the Earth's Crust, ed., Vinogradov - Israel Prog. of Sci. Transl., Jerusalem, p. 456-471.

Temple, A. K. and R. M. Grogan (1965), "Carbonatites and Related Alkal ic Rocks at Powderhorn, Colorado," Econ. Geol., Vol. 60, p. 672-693.

Vidale, R. J. (1978), "The Hignest Temperatures Recorded by the Ok lo Mineral Phase Assemblages and Rock Textures," in IAEA Natural Fission Reactors Proc., p. 235-241.

Wacks, M. and R. Post (1980), The State of Waste Disposal Technology, Mill Tailings and Risk Analys is Models, Vol. I and II, Engineering Experiment Station, U. of Ariz., Tucson. 
Wahlberg, J. S. and R. S. Dewar (1965), "Comparison of Distribution Coefficients for Sr Exchange From Solutions Containing One or Two Competing Cations," U. S. Geol. Surv. Bull. 1140-0.

Wahlberg, J. S. et al. (1965), "Exchange Adsorption of Strontium on Clay Minerals," U.S. Geol. Surv. Bull. 1140-E.

Wahlberg, J. S. and M. J. Fishman (1962), "Absorption of Cesium on Clay Minerals," U.S. Geol. Surv. Bull. 1140-A.

Walton, R. D. and G. A. Cowan (1975), "Relevance of Nuclide Migration at Oklo to the Problem of Geologic Storage of Radioactive Waste," in IAEA Libervill Symp. Ok 10 Pnenomena (June), p. 499-509.

Waltz, J. and T. L. Decker (1981) "Hydro-fracturing Offers Many Benefits," Johnson Drillers Journal, August, p. 4-9.

White, A. F. (1979), "Geochemistry of Ground Water Associated With Tuffaceous Rocks, Oasis, Valley, Nevada," U.S. Geol. Surv, Prof. Paper, 712-E.

Winchester, J. W. (1979), "Long Term Geochemical Interactions of High Active Waste With Crystalline Rock Repository Media," in McCarthy, ed., p. $345-347$.

Winograd, I. J. (1975), "Hydrologeologic and Hydrochenical Franework, South-Central Great Basin, Nevada-Calif. with Special Reference to the Nevada Test Site," U.S. Geol. Surv. Prof, Paper 712-E.

Wyllie, P. J. and 0. F. Tuttle (1960), "System CaO- $\mathrm{CO}_{2}-\mathrm{H}_{2} \mathrm{O}$ and The Origin of Carbonatites," Journal of Petrology, Vol, 1 No. 1. 


\section{REFERENCES (CONT'D)}

\section{B. Hydrothermal Ores}

Baes, D. F. and R. E. Mesiner (1976), The Hydrolysis of Cations, John Wiley, NY.

Barnes, H. L. ed. (1979), Geochemistry of Hydrothermal Ore Deposits, John Wiley, NY.

Barnes, H. L, and C. K. Czamanskye (1967), "Solubilities and Transport of Ore Minerals," in Barnes, ed., Geochemistry of Hydrothermal Ore Deposits, Wiley, p. 334-381.

Chapman, R. E. (1973), Petroleum Geology, A Concise Study, Elsevier, p. 304.

Dana, E. S., 1966, A Textbook of Mineralogy, John Wiley, NY, P. B5I.

Degen, E. T. and D. A. Ross (196y)), Hot Brines and Recent Heavy Metal Deposits in the Red Sea, Springer-Verlag.

Dickey, P. A. (1969), "Increasing Concentration of Subsurface brines with Depth," Chem. Geol., v. 4, p. 361-370.

Dutt, G. R. and T. W. McCreary (1970), "The Quality of Arizona's Domestic Agricultural and Industrial Waters," Rept. 256, Agric. Exp. Sta., Univ. of Ariz.

Gardner, L. R. (1974), "Organic vs. Incrganic Trace Metal Complexes," Geochim. Cosmochim. Acta, Vol. 38, p. 1297-1302.

Hanor, J. S. (1979), "The Sedimentary Genes is of Hydrothermal Fluids, " in Barnes, ed., Geochemistry of Hydrothermal Ore Deposits, p. 137-172.

Hawkes, H. E. and J. S. Weib (1962), Geochemistry in Mineral Exploration, Harper-Row, NY. 
Helgeson, H. C. (1964), Complexing and Hydrothermal Ore Deposition, Pergamon Press, NY.

Krauskopf, K. B. (1967), Introduction to Geochemistry, McGraw-Hill, p. 72.

Lebedev, L. M. and I. B. Nikitina (1968), "Chemical Properties and Ore Content of Hydrothermal Solutions at Cheleken," Dokl. Akad. Nauk; 555 R, Engl. Transl. Eartn Sci. Sec. 183, p. 180-182.

Park, C. F. and R. A. MacDiarmid (1964), Ore Deposits, Freeman, San Franciso, CA.

Park, F. P. Jr. and R. A. MacDiarmid (1975), Ore Deposits, Freeman, San Franciso, CA.

Perrier, R. and J. Quiblier (1974), "Thickness Changes in Sedimentary Layers During Compaction History, Methods of Quantitative Evaulation", Amer. Assoc. Petrol. Geol. Bull. v. 58, p. 507-520.

Schmidt, G. W. (1973), "Interstitial Water Composition and Geochemistry of Deep Gulf Coast Shales i.ld Sands," Am. Assoc. Petrol. Geol. Bull. v. 57, p. 321-337.

Skinner, B. (1970), "The Many Origins of Hydrothermal Mineral Deposits" in Barnes, ed., Geochemistry of Hydrothermal Ore Deposits, John Wiley, p. 1-21.

Smith, R. M. and A. E. Martell (1976), Complexes, Volumes 1-4, Plenum Press, NY.

Stanton, R. L. (1972), Ore Petrology, McGraw-Hill.

Weissberg, B. (1969), "Gold and Silver Ore Grade Precipitates from New Zealand Thermal Waters", Econ. Geol., Vol. 64, p. 95=108.

Weissberg, B. et al., (1979), "Ore Metals in Active Geothermal Systens", in Barnes ed., Geochemistry of Hydrothermal Ore Deposits, Wiley, p. 738-780. 
White, O. E. (1965), "Saline Waters of Sedimentary Rocks," Am. Assoc. Petrol. Geol. Mem. 4, p. 342-366.

White, D. E. (1968), "Environments of Generation of Some Base Metals Ore Deposits," Econ. Geol., Vol. 63, p. 301-335.

White, D. E. (1974), "Oiverse Origins of Hydrothermal Ore Fluids," Econ. Geol., Vol. 69, p. 954-973.

White, D. E. et al. (1963), "Chemical Composition of Subsurface Waters," U.S. Geol. Surv. Prof. Paper 440-F. 
XI. APPENOICES

$-115-$ 
(BLANK PAGE)

$-116-$ 


\section{A. Additional Discussion, OKlo}

The rare-earths are similar in charge, ionic radius and electronegativity to $\mathrm{V}^{4+}$ and data, consistent with Eh-pH interpretation indicate complete retention. $\mathrm{Pu}, \mathrm{Np}$ and some Am were also retained in host pitchblende while $B i$, plus $\mathrm{Pb}$, formed from Th and $\mathrm{U}$ decay, were locally redistributed but nevertheless retained. En-pH diagrams are not especially useful for alkali, alkaline earths or halide elements, although $B a$ (and thus $R a$ ) as barite exhioits a wide stability field (Brookins, 1978).

Natural rare-earths have not been subject to any major remobilization at Ok lo (Ruffenach, 1978).

Absence of detectable zonation in the isotopic compositions of the uraninite might be caused by a low solubility of uraninite in the Oklo body resulting in insignificant $U$ transport. If $\mathrm{O}_{2}$ and $\mathrm{CO}_{2}$ are in equiliorium with solid assemplage magnetite, hematite and graphite, total uranium mobilities would be less than $10^{-9}$ in the pH range 5 to 6.8 (Duffy, 1978).

Only local migration or "even retention" of alkali and alkaline earth elements in the overall ok lo system is suggested. Migration of $\mathrm{Sr}$ and $\mathrm{Rb}$ (possibly Ba and Cs) has effected movement locally out of reactor zone (Brookins, 1980).

Assuming quantitative retention of $U$, then $R U$ and Te have been removed from rrcks below the reaction zones and redeposited above roughly 10 meters away. The hot aqueous fluids moderating the reactors may have been responsible for transporting these elements (Gancarz et al., 1980).

Some observational evidence indicates migration of Tc. Eh-pH diagrams would suggest retention, however, thermochemical data are not as complete as desirable (Brookins, 1978). 
Redistribution of PD should be (and was) local because in the pH range at OKlo, PbS is stable in the sulfide field arid $\mathrm{PDSO}_{4}$ in the sulpinate field. $\mathrm{RuS}_{2}$ is stable in the pyrite field; $\mathrm{RuO}_{2}$ in the hematite field; $\mathrm{Ru}^{4+}$ substitutes for $\mathrm{Fe}^{3+}$ and $\mathrm{Ti}^{4+}$ (Brookins, 1978).

Molybdenum and $c d$ exhibit no stable phase above the pyrite/hematite fence (text Fig. 5) in the $\mathrm{pH}$ range of 7 to $8.5 . \mathrm{MO}_{3} \mathrm{O}_{8}$ is stable at $\mathrm{pH}$ less than 5.5 and $\mathrm{Cd}(\mathrm{OH})_{2}$ only above $\mathrm{pH}=5.5$ to 10.0 (Brookins, 1978). The wide stability field of $Y_{2}\left(\mathrm{CO}_{3}\right)_{3}$, shows that $\gamma^{3+}$ is only released at $\mathrm{pH}=5.5$ when the carbonate species dissolves. In the case of REE's and $Y$, a major factor is the high degree of ionic substitution of $Y$ and REE for $U^{4+}$ in host pitchblende (Bro0', ins, 1978).

The heavy rare-earths (gadolinium and dysprosium) migrated further and to a greater extent that the light ones (neodymium and samarium). The proportion of fission products carried outside of the reactor is only a few percent but the contamination is still detectable several meters from the core (Naudet, 1978).

$\mathrm{Zr}$ is stable as $2 \mathrm{rSiO}_{4}, \mathrm{ZrO}_{2}$ or in host pitchblende $\left(\mathrm{Zr}^{4+}\right.$ for $U^{4+}$ ) or possibly (U,Zr) $\mathrm{SiO}_{4}$ (Brookins, 1978).

ND is retained due to the large stability field of $\mathrm{Nb}_{2} \mathrm{O}_{5}$ and possible retention in host pitchblende or as oxide-hydroxide phases in gangue minerals (Brookins, 1978).

Rnodium is a native element and $\mathrm{Sn}$ is an oxide under Oklo conditions (Brookins, 1978).

Under high $\mathrm{pH}, \mathrm{Bi}$ may be present as the native metal, as $\mathrm{Bi}_{2} \mathrm{O}_{3}$ $B i_{2} S_{3}$, depending on Eh. In the $O k l o$ Eh-pH range, $B i_{2} S_{3}$ is of prime importance. $\mathrm{Bi}_{2} \mathrm{~S}_{3}$ is more stable than pyrite under slightly oxidizing conditions. The ionic radii of $\mathrm{Bi}^{3+}(1.10 \mathrm{~A})$ is quite different from $\mathrm{Pb}^{2+}$ so it can be argued that $\mathrm{Bi}$ will behave independently of lead. The 
ionic radi $\mathrm{i}$ of $\mathrm{Bi}^{3+}$ is such that, even under slightly oxidizing conditions, it may have been retained in the pitchblende structure to a greater extent than $\mathrm{Pb}^{2+}$.

$\mathrm{NpO}_{2}$ exhibits a wide stability range in terms of $\mathrm{pH}$ and the dioxide is stable to relatively high Eh values. $\mathrm{Np}^{4+}$ has a similar ionic radius to both $\mathrm{U}^{4+}$ and $\mathrm{Pu}^{4+}$. Providing $\mathrm{U}^{4+}$ to $\mathrm{U}^{6+}$ oxidation does not cause extensive damage to the pitchblende crystal structure, Np should be retained in the nost pitchblende (Brookins, 1978).

Retention of Am as observed at $0 \mathrm{k}$ lo may be due to: (1) $\mathrm{Am}^{3+}$ substitution for $\mathrm{U}^{4+}$ due to similar ionic radii; (2) $\mathrm{Am}(\mathrm{OH})_{3} ;(3)$ retention of Eu and Am as carbonates (Brookins, 1978). 
(BLANK PAGE) 


\section{B. Additional Discussion, Uranium Deposition}

1. Vein-Type Deposits

Vein-type uranium deposits include various geologic associations namely pegmatites, aplites, calcite-fluorite-apatite veins or masses, and quartz-fluorite veins. Elemental correlation with uranium vein-type deposits are: $\mathrm{S}, \mathrm{Cu}, \mathrm{Mo}, \mathrm{F}, \mathrm{Zr}, \mathrm{K}, \mathrm{Ni}, \mathrm{Bi}, \mathrm{V}, \mathrm{P}, \mathrm{Nb}, \mathrm{Ta}, \mathrm{Cl}, \mathrm{Co}$ and rare-earths.

Most vein uranium deposits contain pitchblende associated with some quartz, calcite and/or sulfides (pyrite, marcasite) and hematite.

Fluid inclusion studies suggest pitcnblende deposition at low average temperatures of about $190^{\circ} \mathrm{C}$, low formation pressures of about 1 kilobar and low to moderate salinity, but nigh $\mathrm{CO}_{2}$ concentration. Decrease in the $\left[\mathrm{CO}_{2}\right]$ of fluids during the pitchblende stage, suggesting transport as urany? carbonate complexes, is shown in some districts.

Alumina zeolite minerals, i.e., natrolite, scolecite, and laumontite in association with uranium are indicative or high temperature depositional conditions. Some fluid inclusion studies indicate temperatures up to $500^{\circ} \mathrm{C}$.

Formation temperatures have been shown in the range of $200-350^{\circ} \mathrm{C}$ (Poty et al., 1974) for some vein-type pitchblende deposits but most vein-type deposits formed below $150^{\circ} \mathrm{C}$ (Rich et al., 1975).

Fluid inclusion studies indicate that the Beaverlodge-type, vein uranium deposits were formed under conditions of decreasing temperature from $410^{\circ}$ $\pm 30^{\circ} \mathrm{C}$ to $80^{\circ} \pm 10^{\circ} \mathrm{C}$ accompanied by decreasing salinity.

Apparent precipitation mechanisms for the hydrothermal ores are reduction in temperature and pressure (a rapid decrease in conf ining pressure is sometimes indicated). Rich et al., (1976) favor formation of vein-type deposits by reduction mechanisms, as in the Colorado Plateau deposits. It seems unlikely that $\mathrm{CO}_{2}$ evolution will move 
hydrothermal solutions strongly in the direction of pitchblende precipitation. The main effect of the high $\mathrm{CO}_{2}$ pressurts in uraniferous hydrothermal solutions will probadly turn out to be the stabilization of uranyl complexes via a proportionately higher bicarbonate concentration. The presence of hematite as a vein and wall rock mineral in most vein-type uranium deposits is consistent with uranium transport in the +6 yalence state. The deposition of sulfides and arsenides with or shortly after uraninite is consistent with the reduction of $u^{+6}$ to $u^{t 4}$ and the deposition of the very sparingly soluble $\mathrm{UO}_{2}$ at low En. The isotopic compusition of sulfur in sulfides and carbon in carbonates is consistent with the reduction deposition model.

Hematite-rich aquifers can raise the fugacity of oxygen in hydrothermal solutions until equilibrium with hematite has been reached. Calcite $\left(\mathrm{CaCO}_{3}\right)$ together with gypsum and anhydrite $\left(\mathrm{CaSO}_{4}\right)$ in red beds is not uncommon. It has been shown that at geologically reasonad le $\mathrm{CO}_{2}$ pressures, solutions saturated with respect to $\mathrm{CaSO}_{4}$ and $\mathrm{CaCO}_{3}$ can have $\mathrm{O}_{2}$ - fugacity values well within the hematite stability field. This suggests that reducing solutions can react with hematite in red beds, resulting in an increase in $0_{2}$ - fugacity sufficient to convert initially reducing solutions into potential uranium ore fluids (Ricn et al., 1975).

$\mathrm{MnO}_{2}$ is a very potent oxidant because the $\mathrm{Mn}_{3} \mathrm{O}_{4}--\mathrm{MnO}_{2}$ equilibrium nas such a high $\mathrm{O}_{2}$ - fugacity. In the presence of $\mathrm{MnO}_{2}$ nydro- thermal solutions should become highly efficient carriers of $\mathrm{U}^{+6}$.

Common geologic reducing agents: $\mathrm{Fe}^{+2}, 5^{-2}$, and $\mathrm{C}^{\circ}$ (in biotite, hornblende, pyrite, graphite, fossil carbon or hydrocarbon) are capaple or removing molecular oxygen efficiently from surface and subsurface solutions (Ricn et al., 1975). 
Distinction may be made between "hydrothermal" or "metamorphic" reactions. Mckillan (1978) notes pertinent metamorphic reactions of propanle importance in certain uranium deposits, e.g., metamorphic reactions which involve oxidation of ferrous iron and concomitant reduction of uranyl ions, e.g.:

$$
\begin{aligned}
& 3 \mathrm{Ca}(\mathrm{Mg}, \mathrm{Fe})_{5} \mathrm{Si}_{8} \mathrm{O}_{22}(\mathrm{OH})_{2}+2 \mathrm{Ca}_{2} \mathrm{Al}_{3} \mathrm{Si}_{3} \mathrm{O}{ }_{12}(\mathrm{OH})+ \\
& \text { (actinolite) (epidote) } \\
& 2 \mathrm{~K}(\mathrm{Mg}, \mathrm{Fe})_{3} \mathrm{AlSi}_{3} \mathrm{O}_{10}(\mathrm{OH})_{2}+7 \mathrm{H}_{2} \mathrm{O}+8 \mathrm{CO}_{2}+\mathrm{O}_{7}+2 \mathrm{Na}^{+}+ \\
& \text {(biotite) } \\
& \left(\mathrm{UO}_{2}\right)^{2+}+2\left(\mathrm{CO}_{3}\right)^{2-}= \\
& 3 \mathrm{Al}(\mathrm{Mg}, \mathrm{Fe})_{5} \mathrm{AlSi}_{3} \mathrm{O}_{10}(\mathrm{OH})_{8}+2 \mathrm{NaAlSi}_{3} \mathrm{O}_{8}+3 \mathrm{Fe}_{2} \mathrm{O}_{3}+\mathrm{ICCaCO}_{3} \\
& \text { (cnlorite) (albite) (nematite) (calcite) } \\
& +21 \mathrm{SiO}_{2}+\mathrm{HO}_{2}+2 \mathrm{~K}^{+}+2(\mathrm{OH})^{-} \\
& \text {(quartz) (pitchblende) }
\end{aligned}
$$

\section{Redox Reactions Involving Carbon Compounds}

Uranium mineralization associated with $V$, Se and Mo occurs entirely within reduced rocks in the Grants, New Mexico District. In these deposits organic carbonaceous matter may be the main reductant. Organic carbon may be interpreted to serve as reductant for soluble $U^{6+}$ species in solution. This in turn requires no dependence on sulfide-sulfate redox reactions to cause uranium mineralization. Reduction of $\iota^{6+}$ with concomitant oxidation of $\mathrm{C}^{\circ}$ is adequate to explain the uranium ore-calcite association. Some of the early formed organic deposits have been destroyed by uplift and penetration by oxidizating waters, although presently recognized redox fronts may have been 
essentially stationary since the early Tertiary $\left(5 \times 10^{7}\right.$ years-scale $)$ (Brookins, 1980). Uranium concentration in fossil logs has been noted to reach 16.5\% (Breger, 1974).

Humic acid, carried by ground water would have precipitated as humates upon reaching the low Eh, higher pH water tade and within areas of stagnation in interbedded sands and muds. These humates presumably precipitated uranium from alkaline ground water to form coffinite and uraninite. Brcoxins has shown thermodynamically that uranyl aicarbonate may coexist with pyrite under certain conditions but no uranyl species are thermodynamically stable in the presence of caroonaceous matter (Kimberley, 1978).

Evidence suggests that methane may have been the active reductant in ground waters carrying uranium in the Athabasca Formation, Saskatchewan (Langford, 1978).

Interaction of $\mathrm{CH}_{4}$ with oxidized, uranium bearing ground water may have occurred at $200^{\circ} \mathrm{C}$ and 1000 bars. In the presence of the mineral ouffer quartz-fayalite-magnetite, $\mathrm{CH}_{4}$ and $\mathrm{CO}_{2}$ predominate in a gas phase in equilibrium with carbon (graphite).

Several uranium deposits are located above or near producing oil fields for example, Lance Greek, Wyoming and Cement, Oklahoma. Reductants include $\mathrm{H}_{2} \mathrm{~S}$, petroleum, humic acid and bitumins. The uranium was originally mobilized in salt solutions. Some uranium has precipitated as organo-uranium complexes in asphalt (Von Backstrom, IAEA, 1974).

\section{Redox Reactions Invoiving Sulfate/Sulfide}

Sulfide/sulfate equilibrium and hematitic oxidized rocks indicate precipitation of oxidation-mobilized uranium, to form roll-type ore at Grants, New Mexico. Deposition was apparentiy controlled by sulfide/sulfate equilioria (Brookins, 1980). 
Also for Hyoming roll-type deposits the assumption is that most of the reduction of $U^{6+}$ takes place at the iron redox front defined by the Eh-pH Doundary between pyritiferous-bearing reduced rocks and hematitic bearing oxidized rocks. As solutions percolating througn the rocks encounter this redox front, oxyions of uranium, vanadium, selenium, molybdenum and arsenic are reduced. Organic matter is very common in the reducing zones. Decreasing En is generally concomitant with decreasing pH, as pyrite is axidized,

oxidation of pyrite by increasingly oxidizing ground water flow causes sulphite to form. Sulphite disproportionation into $\mathrm{SO}_{4}^{2-}$ and $\mathrm{HS}^{-}$developed the final reducing mechanisit for uranium precipitation in the ore rolis (Dah) and Hagmaier, 1974).

Pyrite and uranyl carbonate complexes $\Rightarrow$ uraninite and some combination of $\mathrm{CO}_{2}$, iron oxides, $\mathrm{SO}_{4}^{2-}$, and lower $\mathrm{pH}$ (Morton, 1974).

Uranium mineralization was accompanied by formation of $\mathrm{Pb}, \mathrm{Zn}, \mathrm{Cu}, \mathrm{Ni}$ and Co sulfides or arsenides in Hungarian deposits indicating other redox reactions of sulfide/sulfate character (Barthel, 1974).

\section{Clay Reactions}

Brookins (1980) reviews the complex interactions and interrelationsnips between silicates (namely clays) iron, sulphur, soluble ions, i.e., U, Se, Mo, As and organic caroon under certain Eh-pH and temperature conditions. This generally relates to near surface environments of $25^{\circ}$ to $60^{\circ} \mathrm{C} ; 60^{\circ} \mathrm{C}$ is characteristic of the clay-rich, uranium-producing Morrison Formation's burial temperatures. "Chlorite-pyrite reactions may be very important for recognizing areas favorable for (existing) urarium inineralization". Uranyl dicarbonate $+\mathrm{H}_{4} \mathrm{SiO}_{4}+\mathrm{H}_{2} \mathrm{O}+\mathrm{Mg}^{2+}+$ montmorillonite = coffinite $+\left(\mathrm{HCO}_{3}^{-}\right)+$ $\mathrm{Mg}$-chlorite. $\mathrm{H}_{4} \mathrm{SiO}_{4}+\mathrm{Mg}^{2+}$ are present due to organic acid attack on pre-existing minerals. Should $\mathrm{HS}^{-}$(or $\mathrm{H}_{2} \mathrm{~S}$ ) de present, it will conceivady 
react with $\mathrm{Fe}^{2+}$ released from altering montmorillonite to form pyrite or marcasite. "Reactions involving organic carbonaceous matter, clay mineral formation, and pyrite (or marcasite) formation penecontemporaneous with the uranium mineralization can be advocated." "Uranium ore zones (Grants, New Mexico) in reduced rocks are typically enriched in some combination of chlorite, mixed layer illite-montmorillonite, illite and Mg-niontmorillonite and are usually depleted in the Na-rich montmorillonite more typical of barren rocks". (Brookins, 1980).

\section{Precipitating Ligands}

Precipitating ligands, where $\mathrm{CO}_{2}$ pressure in soil and ground water are relatively low because of the absence or paucity of organic activity in the soil are: (with resultant uranium mineral) vanadate (carnotite and tyuyamunite), phosphate (autunite group), silicate (uranopnane), arsenate. NOTE: Low $\mathrm{CO}_{2}$ pressure may be due to other factors other than paucity of organic material.

Calcrete (calicne like) deposits in Australia, as mechanisms for uranium deposition, involve the transport of uranyl dicarbonate under high $\mathrm{CO}_{2}$ pressure to the valley floor. Loss of $\mathrm{CO}_{2}$ pressure results in precipitation of calcrete; oxidation of $v^{+4}$ to $v^{+5}$ (likely as the water moves through the calcrete) results in precipitation of carnotite (Langford, 1978). So the presence of $v^{+5}$ in an oxidizing environment may enhance precipitation of uranium carbonate complexes yielding carnotite. Favorable conditions are initiated by the loss of $\mathrm{CO}_{2}$ and precipitation of calcrete. 


\section{Additional Discussion of Uranium Mobility}

Uranium transport generally occurs in oxidizing surface and ground waters as uranyl species, most often as $\mathrm{UO}_{2}^{+}$or uranyl fluoride phospnate or carbonate complexes which are formed by high $\mathrm{CO}_{2}$ pressures (IAEA, 1974). $\mathrm{UO}_{2}^{+}$is apparently a weak complexer -- the existence of soluble $U^{+5}$ greatly increases the mobility of $U$ for a wide range of natural conditions, as indicated by evidence for stable $\mathrm{JO}_{2}^{+}$complexes in reduced waters at $\mathrm{pH}$ values below 7 .

Solubility curves for autunite and carnotite versus $\mathrm{pH}$ show minimum [U] (about $10^{-7} \mathrm{M}$ ) at $\mathrm{pH}=6$. The adsorption curve for uranium by kaolinite also shows a minimum $[U]$ at $\mathrm{pH}=6\left(10^{-8}\right.$ moles $)$. "Inferences made from Eh-pH diagrams indicate that uranium, vanadium, selenium, molybdenum, arsenic and antimony may have been transported as a group," (Brockins, 1980).

Uranium decay products generaliy do not form soluble compounds so isotopic disequilibrium is generally due to removal of uranium under oxidizing conditions or uranium addition under reducing conditions (decay products include: $\mathrm{Pa}-234$, Th-230, $\mathrm{Ra}-226, \mathrm{Rn}-222$ and $\mathrm{Pb}-210)$. Uranium is the most modile (non-gaseous) elemerit of this series (Dyck, 1978).

Uraninite is 8 times more soluble in pure water at $100^{\circ} \mathrm{C}$ than $25^{\circ} \mathrm{C}$, however, the decreasing stability of uranyl carbonate complexes above $25^{\circ} \mathrm{C}$ would induce precipitation of $\mathrm{UO}_{2}$ upon elevated temperature.

The solubility of $\mathrm{UO}_{2}$ in pure water at 750 bars increases to $275 \mathrm{ppm}$ at $275^{\circ} \mathrm{C}$ and then appears to decrease. The maximum is $260^{\circ} \mathrm{C}$ for $\mathrm{UO}_{2} / \mathrm{LO}_{3}$; with a rapid decrease below $200^{\circ} \mathrm{C}$. Solubility of uranium in solutions in equilibrium with uraninite and schoepite at $25^{\circ} \mathrm{C}$ increased with increasing oxygen fugacity and/or with decreasing $\mathrm{pH}$. (In pure water $P_{\mathrm{CO} 2}=0$ ). $\mathrm{pH}$ has a profound effect but increases in $U$ with decreasing pH becomes less important at temperatures above $100^{\circ} \mathrm{C}$ (Rich et al., 1975). 
(BLANK PAGE)

C-2 


\section{Actinide Geochemistry}

1. Uranium

Reducing materials such as organic carbon and iron sulfides are sufficient to prevent the oxidation of uranium (at elevated temperatures $\left(200-300^{\circ} \mathrm{C}\right)$ in shale). Uraninite, $U^{+4}$ is stable in the presence of heinatite, which is the only redox oxide in many shales. Uraninite is found in association with nematite in geological environments. Thus hematite alone is not sufficient to oxidize uranium, although it would not reduce any uranium already present in the hexavalent state (Freeborn et al., 1980).

$\mathrm{UO}_{2}$ in solutions containing very low oxygen levels (reducing condicions) may also form hydrate films due to local oxidants such as $0_{2}$ and $\mathrm{H}_{2} \mathrm{O}_{2}$ produced by strong radiation.

Uranium solubility is influenced by: (1) water temperature (directly proportional); (2) pH, (greater solubility at high and low pH's, minimum soluoility in neutral pH range of about $\mathrm{pH}=6$ to 8.5 ); (3) gas content (increased $\mathrm{O}_{2}$ and $\mathrm{CO}_{2}$ content increases solubility); (4) electrochemical (nobility of uranium is greatly enhanced at high Eh values); (5) anionic composition of solution, (dicarbonate ions are most efficient at increasing $U$ mobility since they cause formation of soluble and stable uranyl complexes under oxidizing conditions). Anions like the halogens, $\mathrm{SO}_{4}=$ and $\mathrm{HPO}_{4}^{-}$have similar but profound less effect.

For example: $\quad \mathrm{UO}_{2}\left(\mathrm{CO}_{3}\right)_{2}^{2-} \pm \mathrm{UO}_{2}^{2+}+2 \mathrm{CO}_{3}^{2-} \quad \mathrm{K}=10^{-14.5}$

Uranium may precipitate in the sexivalent (uranyl) state by a variety of anions, including bicarbonate if certain conditions prevail.

The dominant mechan ism sueculated for uranium precipitation in ore deposition is by reduction, notably by organic matier or $\mathrm{Fe}^{+2}$, to form $\mathrm{UO}_{2}$ or one of its hydrates (extremely insoluble hydroxides). 


\section{Thorium}

Th resembles hafnium in terms of geochemical behavior. $\mathrm{Th}^{4+}$ is the dominant oxidation state. Thorium dioxide hydrate forms positively charged colloidai particles. The high charge on $\mathrm{Th}^{4+}$ makes it susceptible to complex formation.

Thorium-230 is somewhat more mobile than Th-232, just as U-234 is somewhat more mobile than $U-238$, because increased radiation damage of the crystal lattice due to a shorter half-ife produced microfractures and dislocations preferentially around Th-230 in mineral crystal structures (Dyck, 1978).

In sandstone, Th is mainily concentrated in the resistant heavy minerals. In the sedimentary cycle, Th behaves similarly to Sc. Because of the very high ionic potential of $\mathrm{Th}^{4+}$, only very small amounts of th can be kept in ionic solution in near neutral waters owing to the precipitation of highly insoluble $\operatorname{Tn}(\mathrm{OH})$ (Brookins, 1980).

Thorium is extremely immobile in the surficial environiment due to precipitation as hydroxide (Dyck, 1978).

Thorium undergoes extensive hydrolys is in aqueous solution at pH higher than 3; the species formed are complex and dependent an the conditions of $\mathrm{pH}$, nature of anions, concentration, etc. Complex species, which may also be hydrolyzed and polymerized, can form (Cotton and wilkinson, 1967).

\section{Protactinium}

$\mathrm{Pa}^{+5}$ is the dominant oxidation state. Aqueous chemistry of $\mathrm{Pa}^{+5}$ is somewhat like tantalum and niobium. Pa occurs in pitchblende with uranium,

In aqueous solution polymeric ionic species and colloidal particles form resulting in precipitation (generally insoluble). 
4. Neptunium, plutonium, americium

The dioxides of $\mathrm{Np}, \mathrm{Pu}$ and $\mathrm{Am}$ are insoluble at normal environmental $\mathrm{pH}$. Chloride forms soluble compounds/complexes with Np, Pu and Am, but the fluorides are generally insoluble. It is expected that carbonates species can enhance mobility of $\mathrm{Np}, \mathrm{Pu}, \mathrm{Am}$, i.e., analogous to uranium, however little appears to be known. Am does form a carbonate anion which is soluble under controlled and simple laboratory conditions. 
(BLANK PAGE)

D-4 


\section{E. Effects of En on Actinide Geochemistry}

The dioxides of $\mathrm{U}, \mathrm{Np}, \mathrm{Pu}$ and $\mathrm{Am}$ are insoluble at normal envirolimental $\mathrm{pH}$. At $\mathrm{pH}=7, \mathrm{U}^{4+}$ concentration is negligible; at $25^{\circ} \mathrm{C}, \mathrm{V}^{6+}$ concentration is $10^{-5} \mathrm{M}$ to $10^{-8} \mathrm{M}$.

Mineralization in the Grants Belt, New Mexico, occurs entirely within reduced rocks. In these occurrences, organic matter may be the main reductant (Brookins, 1980).

It is generally thought that most reduction of $U^{6+}$ and deposition of $\mathrm{U}^{4+}$ in the Wyoming roll deposits took place at the iron redox front defined by the En-pH boundary between pyritiferous reduced rocks and hematitic oxidized rocks.

The presence of organic matter and iron sulfides is sufficient to prevent the oxidation of uranium at elevated temperature $\left(200-300^{\circ} \mathrm{C}\right)$ in shale. $u^{4+}$ is stable in the presence of hematite. Thus hematite alone is not sufficient to oxidize uranium. Uranium already present in tne hexavalent state is not reduced in the presence of nematite (Freeborn et al., 1980).

Uranyl dicarbonate may coexist with pyrite under certain conditions but no uranyl species are thermodynamically stable in the presence of carbonaceous matter (Kimberley, 1978).

Oxidation of pyrite by incursing ground water would cause sulpnite to form. Sulphite disproportionates into $\mathrm{SO}_{4}^{-2}$ and $\mathrm{HS}^{-}$which may reduce and precipitate the uranium ore in a roll deposit (Morton, 1974).

Brookins (1980) suggests that complex reactions involying carbonaceous matter, clays, iron, sulfur and soluble ions, like uranyl may create reducing conditions and result in the precipitation of uranium with chlorite. 
Soviet researchers believe that reducing fluids can nevertheless carry hexavalent uranium in the form of urany1 carbonate complexes under high partial pressures of $\mathrm{CO}_{2}$. A drop in $\mathrm{CO}_{2}$ pressure is then the mechanism precipitating uranium in the oxide form (IAEA, 1974\}.

The aqueous chemistry of Pu (also Np and Am) is complicated by the fact that all four oxidation states can coexist in appreciable concentration in solution.

There is evidence for a stable $\mathrm{UO}_{2}^{+}$complex in raduced water at $\mathrm{pH}$ values below 7. $40_{2}^{+}$is apparently a weak complexer but the existence of soluble $U^{+5}$ greatly increases the mobility potential of $U$ for a wide range of natural conditions (Brookins, 1980). 


\section{F. Effects of pH on Actinide Geochemistry}

Concentration of $\mathrm{U}^{4+}$ at $\mathrm{pH}$ of 7 is negligible at $25^{\circ} \mathrm{C}$. Concentration of $\mathrm{U}^{4+}$ at $\mathrm{pH}$ of 4 is $10^{-6} \mathrm{M}$. Concentration of $\mathrm{U}^{6+}$ at $\mathrm{pH}$ of 7 is

$10^{-5.1} \mathrm{M}$. Concentration of $U^{5+}$ at oH of 4 is $10^{-2} \mathrm{M}$ (or $4 \mathrm{~g} / \mathrm{liter}$ ) (Krauskopf, 1967).

The important uranyl minerals are least soluble at pH's within the range 5 to 8.5. Above $\mathrm{pH}=8.5$ more soluble uranyl carbonate complexes form and below $\mathrm{pH}=5$ more soluble hydroxide of $\mathrm{UO}_{2}^{2+}$ and other cations form.

The solubility of carnotite and autunite show a minimum (about $10^{-7}$ moles) for $\mathrm{pH}=6$. Hydroxide complexes of $U$ may reach significant concentration in reduced ground water above a $\mathrm{pH}=8$ (Langmuir, 1978).

Thorium undergoes extensive hydrolysis in aqueous solutions at a pH nigher than 3, forming a very insoluble hydroxide (Cotton and Wilkinson, 1967; Dyck, 1978).

There is evidence for a stable $\mathrm{U0}_{2}^{+}$complex in reduced water at $\mathrm{pH}$ values below 7 .

Tyuyamunite is several times more soluble than carnotite but also has a minimum solubility near I ppu U at about $\mathrm{pH}=7$ (Langmuir, 1978).

At $\mathrm{pH}$ values of 0 to 4 uranium sulfate and uranium fluoride complexes are important soluble species (Langmuir, 1978; Brookins, 1980).

At common ground water concentrations of sulfate and $100 \mathrm{ppm}, \mathrm{UO}_{2} \mathrm{SO}_{4}^{\circ}$ may be a significant species up to $\mathrm{pH}=7$. Silica forms a relatively weak complex $\left(\mathrm{UU}_{2} \mathrm{SiU}(\mathrm{OH})_{3}^{+}\right.$which is most important at $\mathrm{pH}=6$ (Langmuir, 1978).

Within the PH range (6.6 to 8.3) of ground waters in the Wind River Formation, Wy,, both uranyl phosphate and carbonate complexes can predominate.

Rich et al. (1975) have found that $\mathrm{UO}_{2} \mathrm{~F}_{6}^{4-}$ is stable up to a $\mathrm{pH}=6.7$ at $25^{\circ} \mathrm{C}$ and $\mathrm{UO}_{3}$ forms a soluble fluoride complex, possibily $\mathrm{UF}_{2}^{2+}$ which is stable up to $\mathrm{pH}=4$. 
Transport of uranium by $\left(\mathrm{UO}_{2}\left(\mathrm{HPO}_{4}\right)_{2}\right)^{2-}$ for total dissolved contents of pnosphorous equal to $0.1 \mathrm{ppm}\left(10^{-6} \mathrm{M}\right)$ is likely near $\mathrm{pH}=7$. However, the most suitade conditions for the precipitation of autunite is at atmospheric $\mathrm{CO}_{2}$ pressure and pH near 7 (Langmuir, 1978). 


\section{G. Effects of Mineralogy on Actinide Geochemistry}

Reducing materials such as organic carbon and iron sulfides are sufficient to prevent the oxidation of uranium at elevated temperatures $\left(200-300^{\circ} \mathrm{C}\right)$ in shale. Uraninite is stable in the presence of nematite, which is the only significant oxidizing mineral in many shales. Uraninite is commonly associated with hematite in the geologic environment. Thus hematite alone is not sufficient to oxidize uranium (Freeborn et al., 1980).

Most vein uranium deposits contain pitcholende associated with at least some quartz, calcite and/or sulfides and hematite. Uranium $\left(\mathrm{UO}_{2}\right)$ in metasomatic and regional metamorphic terrains is associated with calcsilicate and calcite-fluorite-apatite assemblages.

Brookins (1980) observes that uranium ore zones at the Grants, New Mexico deposits from reduced rocks are typically enriched in some combination of chlorite, mixed-layer illite-montmorillonite, illite, or Mg-montmorillonite and usually depleted in the Na-ricn montmorillonite more typical of barren zones. He proposes that reactions involving organic matter, clay mineral formation and pyrite formation are penecontemporaneous with uranium mineralization.

Uranium is concentrated in petrified logs up to $16.5 \%$ (Breger, 1974). Mineralogical effects are treated further in this report under the discussions of sorption. 
(BLANK PAGE)

G-2 


\section{H. Effects of Anions on Actinide Geochemistry}

1. Carbonate

For En values above $-0.05 \mathrm{v}$, increases in $\mathrm{CO}_{2}$ pressure in ground water to $10^{-2}$ atm increases the solubility of $\mathrm{UO}_{2}$ by more than 1000 times (due to increased activity of carbonate).

It is not possible to equivocally state whether uranium dicarbonate or $\left(\mathrm{UO}_{2}\left(\mathrm{HPO}_{4}\right)_{2}\right)^{2-}$ is the dominant species for transport of uranium $(4+)$ in the $\mathrm{PH}$ range of 7-8 (Langmuir, 1978).

Carriers for $\mathrm{U}(4+)\left(\right.$ stable $\left.a \pm 150^{\circ} \mathrm{C}\right)$ include: $\left(\mathrm{UO}_{2}\left(\mathrm{CO}_{3}\right)_{2}\left(\mathrm{H}_{2} \mathrm{O}\right)_{2}\right)^{2-}$, $\left(\mathrm{UO}_{2}\left(\mathrm{CO}_{3}\right)_{3}\right)^{4-}, \mathrm{Na}_{2}\left(\mathrm{UO}_{2}\left(\mathrm{CO}_{3}\right)_{2}\right), \mathrm{Na}_{4}\left(\mathrm{UO}_{2}\left(\mathrm{CO}_{3}\right)_{3}\right)$.

At a common ground water $\mathrm{CO}_{2}$ pressure of $10^{-2} \mathrm{~atm}$, and $25^{\circ} \mathrm{C}$, the uranyl carbonate complexes are the major species in pure water down to $\mathrm{pH}=5$, and down to $\mathrm{pH}=5.8$ at $\mathrm{CO}_{2}$ pressure $=10^{-3.5}$ atm.

With increasing temperature, the carbonate complexes become less important, therefore at $100^{\circ} \mathrm{C}$ and $\mathrm{CO}_{2}$ at $10^{-2}$ atm, the uranyl carbonate complexes are minor at all pH's (Langmuir, 1978). (Note: There is some debate as to the stability and influence of carbonate complexes at elevated temperatures.)

Carbonate, sulfate and fluoride complexes inhibit sorption of uranyl ion in the $\mathrm{pH}$ range of 5 to 8.5 on clays, phosphorites and iron and titanium oxyhydroxides (Langmuir, 1978).

Thermodynamically, uranyl dicarbonate may coexist with pyrite under certain conditions (Kimberly, 1978).

Fluid inclusion studies of vein-type uranium deposits universally exhibit nigh $\mathrm{CO}_{2}$ content in the fluids. There is debate as to the interpretation of tnis ooservation. Some investigations propose that a loss of $\mathrm{CO}_{2}$ by boiling 
or effervescence is the mechanism for the precipitation of uranium complexed Dy carbonate. Others suggest that high $\mathrm{CO}_{2}$ pressure in uraniferous hydrothermal solutions enhances the solubility and, therefore the mobility of uranium out that precipitation of ore is due to reduction. Still others question the stability of the uranium carbonate complexes at elevated temperatures (Kimberly, 1978; Rich et al., 1978; Pocy et al., 1974; Langford, 1978; Langmu ir, 1978; IAEA, 1974).

The solubility of oxidized uranium $(4+)$ is greatly increased by the formation of carbonate complexes: $\mathrm{UO}_{2}\left(\mathrm{CO}_{3}\right)_{2}=\mathrm{UO}_{2}^{++}+2 \mathrm{CO}_{2}=\mathrm{k}=10^{-14.6}$, $\mathrm{UO}_{2}\left(\mathrm{CO}_{3}\right)_{3}^{4-}+\mathrm{UO}_{2}\left(\mathrm{CO}_{3}\right)_{2}+\mathrm{CO}_{3}=\mathrm{K}=10^{-3.8}$. At $0.01 \mathrm{M}$ total carbonate, the uranium concentration in solution would be ten times as much as estimated for a carbonate-free solution. The effect of the caroonate complex would increase rapidly as the amount of $\mathrm{CO}_{3}^{=}$is increased, eitner by dissolving more carbonate or oy raising the $\mathrm{pH}$ (Krauskopf, 1967).

Carnotite (and other uranyl minerals) is most stable (least soluble) at low $\mathrm{CO}_{2}$ pressure such as in ground water in semi-arid areas. Ground water in equilibrium with carnotite could conceivably hold less than 1 ppo of uranium at $\mathrm{pH}=5.5$ to 7.5 (Langmuir, 1978).

The Soviets have noted that reducing fluids can nevertheless carry hexavalent uranium as uranyl carbonate ions. They suggest that a drop in $\mathrm{CO}_{2}$ pressure is then enough to precipitate uranium in the oxide form (IAEA, 1974).

The role of carbonate complexes for other actinides is expected to be analogous but perhaps to a lesser mobilizing degree than for uranium. Little mention of other actinide carbonate complexing was noted in the literature 
reviewed. Am does form a carbonate anion which is soluble, given controlled and simple laboratory conditions.

In the actinide series the energies of the outer orbitals are about comparable over a range of atomic numbers, especially for uranium through americium, and since the orbitals overlay spatially, bonding can involve any or all of them. Actinides, therefore have a tendency to form complexes and bond covalently.

The presence of $\mathrm{NaHCO}_{3}$ increases the uranium concentration in solutions equilibrated with $\mathrm{UO}_{2}$ and $\mathrm{UO}_{3}$ througnout the hydrotnermal range (Rich et a1., 1975).

Silva et al. (1979) state that the solubility of Am and Cm carbonate is very low $\left(10^{-41}\right)$.

\section{Pnosphate}

It is not possible to unequivocally state whether uranium dicarbonate or $\left(\mathrm{UO}_{2}\left(\mathrm{HPO}_{4}\right)_{2}\right)^{2-}$ is the dominant species for transport of $\mathrm{U}$ in the $\mathrm{pH}$ range 7-8 (Langmuir, 1978).

Transport of uranium by $\left(\mathrm{UO}_{2}\left(\mathrm{HPO}_{4}\right)_{2}\right)^{2-}$ for total dissolved contents of phosphorus equal to $0.1 \mathrm{ppm}\left(10^{-6} \mathrm{M}\right)$ is likely near $\mathrm{pH}=7$; at lower concentration of total dissolved phosphorus (0.01-0.001 ppin) uranium dicarbonate will be more important (Langmuir, 1978).

Over the $\mathrm{pH}$ range of most natural waters, practically all the phosphorus is present as $\mathrm{H}_{2} \mathrm{PO}_{4}^{-}$and $\mathrm{HPO}_{4}^{2-}$ on their metal complexes regardless of the oxidation potential. Phosphcrus concentration in ground water rarely exceeds $1 \mathrm{ppm}$.

For typical ground water concentrations of $0.1 \mathrm{ppm}$ phosphorus, the $\left(\mathrm{UO}_{2}\left(\mathrm{HPO}_{4}\right)_{2}\right)^{2-}$ will predominate over the hydroxyl complexes in pure water from $\mathrm{pH}=4$ to above 10 (Langmuir, 1978). 
A 100 -fold increase in uraninite solubility results at $\mathrm{pH}=6$ when a typical ground water phosphate level of $0.1 \mathrm{ppm}$ is introduced and the En exceeds $0.05 \mathrm{v}$.

The most suitable conditions for precipitation of autunite is at atmospheric $\mathrm{CO}_{2}$ pressure and $\mathrm{pH}$ values near 7 . In the absence of vanadium the least soluble and most oxidized uranyl minerals are the autunites. Phosphate concentration must exceed $\left[\mathrm{VO}_{4}\right]$ by roughly 500 times before potassium autunite will precipitate instead of carnotite (Langmuir, 1978).

\section{Halogens}

A major mechanism proposed for uranium, thorium and rare earth transport in the hydrothermal environment is halide complexing. The abundance of salts in uraniferous carbonaceous clay and fluid inclusions is cited as evidence for the role of brines in uranium mobility at elevated temperatures (El Shazy et a)., 1974; IAEA, 1974; Kimberly, 1978).

Langmuir (1978) says "brınes are excellent scavengers for uranium." Uranous fluorides are impurtant at typical fluoride concentrations in reducing ground waters below $\mathrm{pH}=4$. They enhance solubility (Langmuir, 1978). In pegmatites, volatile fluorides which are easily hydrolized, include: $\mathrm{UF}_{4}, \mathrm{UF}_{6}, \mathrm{UO}_{2} \mathrm{~F}_{2}$ and $\mathrm{U}\left[\mathrm{SiF}_{6}\right]_{2}$.

Rich et al. (1975) find that $\mathrm{UO}_{2} \mathrm{~F}_{6}^{-4}$ is stable up to a $\mathrm{pH}=6.7$ at $25^{\circ} \mathrm{C}$ and that $\mathrm{UO}_{3}$ forms a soluble fluoride complex, possibly $\mathrm{UF}_{2}^{2+}$, which is stable up to a $\mathrm{pH}=4$. The same authors suggest that in the $\mathrm{pH}$ range of most nydrothermal solutions, fluoride complexes are unstable and therefore, not a particularly important transport mechanism.

In the system $\mathrm{U}-\mathrm{O}-\mathrm{H}_{2} \mathrm{O}-\mathrm{HCl}$ the concentration of uranium in a solution saturated with respect to $\mathrm{UO}_{3} \cdot \mathrm{H}_{2} \mathrm{O}$ or $\mathrm{UO}_{3} \cdot 2 \mathrm{H}_{2} \mathrm{O}$ (about $10 \mathrm{ppm}$ in a neutral solution) rises rapidly with decreasing pH and rises very slowly 
with the addition of $\mathrm{NaOH}$ (Rich et al., 1978). For hydrothermal solutions, Rich et al. (1975) suggest that the effects of $\mathrm{NaCl}$ is probaoly small in the pH range where neutral complexes are dominant. $\mathrm{NaCl}$ would increase the solubility of $\mathrm{UO}_{2}$ and $\mathrm{UO}_{3}$ hydrates in the alkaline range due to the effect of increasing ionic strength on the activity coefficients of the carbonate complexes and in acid solutions where $\mathrm{UO}_{2}(\mathrm{OH})^{+}$and $\mathrm{UO}_{2}^{2+}$ are dominant species.

Halogen complexes inhioit sorption and may favor desorption under acid conditions (Langmuir, 1978).

\section{Sulfate/Sulfide}

Sulfate complexes also inhibit sorption and may favor desorption under acid conditions (Langmuir, 1978).

Mineralization, after remobilization of uranium, to form roll-type ore at Grants, New Mexico was apparently controlled by sulfide/sulfate equilibria (Brookins, 1980).

In the Wyoming roll deposits the reduction of $v^{6+}$ is thought to take place at the iron redox front defined by the Eh-pH boundary beiween pyritiferous reduced rocks and hematite oxidized rocks. The following references discuss sulfur as a reductant: Dahl and Hagmaier, 1974; Morton, 1974; Barthel, 1974; von Badckstrom in IAEA, 1974.

At $\mathrm{pH}$ values of 0 to 3 uranium sulfate complexes are important soluble species. At common ground water concentrations of sulfate, $100 \mathrm{ppm}, \mathrm{UO}_{2} \mathrm{SO}_{4}^{\circ}$ may be significant up to $\mathrm{pH}=7$ (Brookins, 1980; Langmirir, 1978).

The formation of sulfate complexes of $\mathrm{Np}^{4+}$ and $\mathrm{NpO}^{2+}$ is strong enough to cause dissociation of $\mathrm{NpO}_{2}^{+}$(Cotton and Wilkinson, 1967). 


\section{Silica}

Silica forms a relatively weak complex $\mathrm{NO}_{2} \mathrm{SiO}(\mathrm{OH})_{3}^{+}$which is most important at $\mathrm{pH}=6$. In general, the uranyl silicate complex is unimportant (Langmuir, 1978).

Very high silica and low total pitosphate concentrations are required to precipitate uranophane instead of autunite (Langmuir, 1978).

\section{Hydroxide}

Under conditions of low total dissolved carbonate and phosphate, hydroxide complexes may be important (Langmuir, 1978, Brookins, 1980).

Tharium is extremely imnobile in the surficial environments due to precipitation of insoluble hydroxide (Dyck, 1978). Significant hydroxide complexes are $\mathrm{UO}_{2} \mathrm{OH}^{+},\left(\mathrm{UO}_{2}\right)_{2}\left(\mathrm{OH}_{2}^{2+}\right),\left(\mathrm{UO}_{2}\right)_{3}(\mathrm{OH})_{5}^{+}$(Langmuir, 1978).

The uranyl ion forms a soluble hydroxide at $\mathrm{pH}=4$ with a concentration of $5 \mathrm{~g} / \mathrm{l}$ of uranium in water. In acidic solutions at $25^{\circ} \mathrm{C}, \mathrm{U}^{6+}$ is presently largely as $\mathrm{UO}_{2}(\mathrm{OH})^{+}$and $\mathrm{UO}_{2}^{+2}$ (Rich et al., 1975).

Only at pH's above 8 would hydroxide complexes reach significant concentration in reduced ground water (Langmuir, 1978).

The maximum concentration of tetravalent elements in solution is limited by the precipitation of hydroxides, which might be changed into dioxides (Allard, 1979$)$. The tendency for hydrolysis is: $\mathrm{Am}>\mathrm{Pu}>\mathrm{Np}>\mathrm{U}$ and $\mathrm{M}^{4+}>\mathrm{MO}_{2}^{2+}>\mathrm{H}^{3+}>\mathrm{MO}_{2}^{+}$(Cotton and Wilkinson, 1967). 


\section{Sorption Effects on Uranium}

Decreasing sorption factors on various media.

$8 \times 10^{4}$ to $10^{6}$ for $\mathrm{Ti}(\mathrm{OH})_{4}$ (amorphous).

$1.1 \times 10^{6}$ to $2.7 \times 10^{6}$, amorphous $\mathrm{Fe}^{3+}$ axyhydroxide.

$10^{4}$ to $10^{6}$, peat.

$4 \times 10^{3}$, fine-grained goethite.

15, phosphorites.

6, montmorillonite.

2, kaolinite.

Data are for a pH range of 5 to 8.5 in the absence of strong uranyl-sulfate, -fluoride and-carbonate complexes which inhibit adsorption. These data suggest that clays are relatively unimportant as concentrators of uranium but may be an important preconcentrating step leading to the formation of both uranyl and uranous minerals. The zeolites--heulandite, stillbite, clinoptilolite, and mordenite--are indicative of low temperature depositional conditions. Uranium has been adsorbed strongly on zeolites within Miocene sandstone and conglomerate in the Tono mine, Japan (Katayama et al., 1974).

"Sorption is generally a more important control on concentrations of trace metals, such as $U$ at low temperatures, than is mineral precipitation or solution. Uranyl sorption in fact is probably an essential preconcentration step in the formation of many reduced and oxidated uranium ores." (Langmuir, 1978).

Sorption medìa include:

1. Organic matter

2. Ferric, manganese, and titanium oxyhydroxides, and;

3. Clays 
"The $\mathrm{pH}$ range of minimum solubility of the uranyl minerals is also the $\mathrm{pH}$ range of maximal sorption on most important natural colloidal materials." "Once uranyl has been adsorbed, it may be reduced to $\mathrm{U}^{4+}$ in uraninite or coffinite by mobile reductants such as $\mathrm{H}_{2} \mathrm{~S}, \mathrm{CH}_{4}$ or by the sorbent itself if the latter is organic matter. If reduction does not follow adsorption, uranyl can be desorbed by increasing alkalinity at constant $\mathrm{pH}$ or raising the pH." (Langmuir, 1978). 


\section{J. Sorption Effects on Selected Elements - Actinides and Lanthanides}

The sorption of $U, P u, A m$ (in $0.68 \mathrm{~N} \mathrm{NaCl}$ solution) onto abyssal red clay was relatively insensitive to $\mathrm{pH}$ at values between 6 to 8 but was greatly diminisned at $\mathrm{pH} 2.7$ (Erickson, 1980). Am, Pu and $\mathrm{Cm}$ are adsorbed by argillite and hornfels. However, differences of up to five orders of magnitude for sorption of lanthanides and actinides is attributed to solution composition (Lynch and Dosch, 1980). "Information from uranium deposits suggests that chlorite will form during the mineralization process from pre-existing montmorillonite or illite or mixed-layered illitemontmorillonite accompanied by fixation of $\mathrm{V}, \mathrm{Mo}, \mathrm{Se}, \mathrm{AS}$, REE, Th, and U," (Brookins, 1980). Sorption of $\mathrm{U}, \mathrm{Np}$, and $\mathrm{Pu}$ is highly dependent on oxidation state. From reduced ground water in granite, the following oxidation states would predominate (and enhance sorption): $\mathrm{Tc}^{4+}, \mathrm{U}^{4+}, \mathrm{Np}^{4+}, \mathrm{Pu}^{3+}$ and $\mathrm{Pu}^{4+}$ (Allard et al., 1979). Sorption of $\mathrm{Np}$ on fresh rock surface in air is strongly correlated to the $\mathrm{fe}^{2+}$ containing minerals (pyrite and biatite). "This is possibly the most important sorption mechanism for nuclear waste isolation since the higher valence actinides tend to be the most mobile. This could mean that $\mathrm{NpO}_{2}^{+}, \mathrm{UO}_{2}^{2+}, \mathrm{TCO}_{4}^{-}$and $\mathrm{PuO}_{2}^{2+}$ could be reduced to less mobile $\mathrm{NpO}_{2}, \mathrm{UO}_{2}, \mathrm{TCO}_{2}$ and $\mathrm{PuO}_{2}$ states, respectively, by $\mathrm{Fe}^{2+}$ (Beall, 1980). In experiments with U, Np, $\mathrm{Pu}$, Am and $\mathrm{Cm}$ in solutions equilibrated with rock material, precipitation or colloid formation were the major reactions for $\mathrm{Pu}$, Am and $\mathrm{C} m$ and perhaps a minor reaction for $U$. In general, the chemical behavior of $\mathrm{Am}$ and $\mathrm{Cm}$ in solutions are quite similar to the trivalent lanthanides. The solubility of Am and $\mathrm{Cm}$ carbonates may be very low $\left(10^{-41}\right)$. If so, carbonate ion, as well as, hydroxide ion may cause precipitation of Am and $\mathrm{Cm}$. Pu probably precipitates as the hydroxide for 
hydrated oxide). Results of contact experiments with basalt, shale and quartz monzonite snowed the following (Silva et al., 1979):

1. rapid sorption during first two weeks;

2. U was moderately adsorbed onto basalt and less onto shale and quartz monzonite; and

3. Np was strongly adsorbed onto shale and only slightly onto basalt and quartz monzonite.

Intense radiation $\left(10^{10} \mathrm{rad}\right)$ damage to the clay structure does not apparently result in the release of soluble species (Haire and Beall, 1979). The same mechanisms which dominate sorption of the lanthanides also dominate sorption of the actinides (Erickson, 1980). Attapulgite clay has a significantly higher affinity for actinides than do kaolinite and montmorillonite. Kaolinite and montmorillonite have very rapid exchange reactions with actinides and rare earths that take less than 15 minutes to come to equilibrium. Attapulgite clay sorption in contrast takes as long as nine days to come to equilibrium (Beal1, 1979). Certain artinides and lanthanides show "tendencies" to sorb by factors of 20-1000x onto halite with clay from simulant brine solutions at $\mathrm{pH}=6.5$ to 7.8 (Dosch, 1979). Increased solution concentration of $\mathrm{Na}$ and $\mathrm{Ca}$ decreased sorption of rare earths on kaolinite and montmorillonite (Beall, 1979).

Cerium and Eu sorption tended to increase with increasing ionic strength of solution. This may be due to enhanced tendency to form radio colioids as the sulfate ion concentration increases. Sorption of $\mathrm{Ce}$ and Eu were appreciably higher for granite and argillite under de-oxygenated conditions, while the values for tuff were unchanged (Erdal et al., 1980). 
Alkaline Earths ( $\mathrm{Ca}, \mathrm{Sr}, \mathrm{Ba}, \mathrm{Ra}$ ). Some retention of $\mathrm{Sr}$ by clay is noted by Spitsyn and Balukova (1979). Sr fixation is much greater in certain mixtures of zeolites than can be expected from the individual minerals. These mixtures involve the poor Sr fixers as well as clinoptilolite with mordenite or phillipsite which are the best for Sr sorption (Komarneni, 1980). $\mathrm{Sr}$ showed little tendency to sorb on any sample from brine simulant solution at $\mathrm{pH}=6.5$ to 7.9 (Dosch, 1979). Increased sorption of Sr and Ba is noted on glass as temperatures are increased from 22 to $70^{\circ} \mathrm{F}$ (Erdal et al., 1979). Humic acid promotes Sr retention. $\mathrm{Na}^{+}, \mathrm{Mg}^{2+}$ and $\mathrm{Ca}^{2+}$ compete with $\mathrm{Sr}^{2+}$, tnereby decreasing $\mathrm{Sr}$ adsorption (Barney, 1979).

$R d$ is adsorbed more than Sr on granite and bentonite, perhaps because the $\mathrm{RaSO}_{4}$ solubility product is lower than for $\mathrm{SrSO}_{4}$ (Allard, 1979).

Cs and Rb. Vermiculite (superior to montmorillonite but not as good as zeolites) has a high capacity for Cs sorption and fixation, depending on CS concentration in the solution and the charge density of the (clay) layers. Amorphous iron and Mg oxides have good sorption capacity for divalent and trivalent ions. Yet, crystalline oxides and hydroxides showed no sorption for Cs and $\mathrm{Rb}$ (Komarneni et al., 1980). Sorption of $\mathrm{Cs}^{+}$on bentonite and crushed granite was about equivalent at $25^{\circ} \mathrm{F}$ in aerated systems. Temperature increases from $25^{\circ} \mathrm{F}$ and $65^{\circ} \mathrm{F}$ reduced $\mathrm{Cs}$ sorption on bentonite, which wouid correspond to an ion exchange process. Cs sorption seems independent of particle size (Allard, 1979). In terms of radiotoxicity, 10 to $30 \mathrm{Ci} / \mathrm{kg}$ of rock is retained by sorption of Cs on clay (Spitsyn and Balukova, 1979). At low Cs concentrations, sorption is very high, but at high concentration, results show a proportional decrease in the relative amount of $C s$ adsorbed 
(Mckinley, 1980). Cs sorption on "Smectite" clay is not affected by pH, and increased temperature increases retention somewhat. Sorption of $\mathrm{Sr}, \mathrm{Cs}$ and $\mathrm{Ba}$ decreased in water with higher dissolved salt. Sorption for Cs, $\mathrm{Sr}$ and $\mathrm{Ba}$ were generally less in de-oxygenated water than for atmospheric water for tuff and argillite; little change was noted for granite (Erdal et al., 1980).

Cs showed little tendency to sorb on any samples from brine simulant solution at $\mathrm{pH}=7.5$ to 8.2 (Dosch, 1979). Both $\mathrm{K}^{+}$and $\mathrm{Na}^{+}$compete with $\mathrm{Cs}^{+}$for sorption sites and their presence, therefore, decreases $\mathrm{Cs}$ sorption. Humic acid promotes sorption (Barney, 1979).

lodine. $I^{*}$ showed little tendency to adsorb on any samples in contact with brine simulant solution at $\mathrm{pH}=6.5$ to 7.9 nor in ground water at $\mathrm{pH}=$ 7.5 to 8.2 (Dosch, 1979). Sorption of $1^{-}$on crushed granite and bentonite is low (Allard, 1979). Some sorption of $I^{-}$is apparent on galena and copper metal under suitable Eh conditions. The Pbo system sorbs $I^{-}$from very dilute solutions (Bird and Lopata, 1980). Fe and Al-hydroxides, clay minerals and $\mathrm{Cu}-, \mathrm{Pb}-, \mathrm{Ag}-$ compounds show retention factors of 100 to 1000 for $\mathrm{I}^{*}$ in reduced ground water. Increased salt ( $4 \mathrm{M} \mathrm{NaCl)}$ in water has a mixed effect on retention (Allard et al., 1980). The diffusivity of both Am and Pu through illitic sea floor sediment is less than the relatively uneffected iodide ion by a factor of one mitlion. "It must be caused by either a chemical transforination of the simple cationic species in solution, such as hydrolysis and attendant formation of an insoluble hydroxide, or by a very strong interaction with the constituent minerals of the sediments." (Fried, 1980).

Technetium. Sorption of $\mathrm{TC}$, under reduced oxygen and $\mathrm{CO}_{2}$ conditions were consistently higher by more than a factor of 40 than under atmospheric 
conditions. Tests were made on granite, tuff and argillite (Erdal et al., 1980). Tc snowed little tendency to adsorb on any samples in contact with brine simulant solution at $\mathrm{pH}=6.5$ to 7.9 or $\mathrm{pH}=7.5$ to 8.2 (Dosch, 1979). Sorption of $\mathrm{TCO}_{4}^{-}$is low on granite and bentonite (in an arated system) (Allard et al., 1979). Organic complexes of $\mathrm{Tc}^{4+}$ with EDTA and $\mathrm{Tc}^{5+}$ with DPTA reduced total TC sorption in soil ( $\mathrm{pH} \sim \sim 8.2$ ), thereby increasing mooility through soil. Sorption of ic on abyssal red clay (oxidizing conditions) was essentially zero at $\mathrm{pH}=8.3$ and 2.6 (Erickson, 1980). $\mathrm{TCO}_{4}^{-}$was removed from solution by argillite (Eleand Shale) under oxidizing conditions, yet hornfels had no affinity for $\mathrm{TCO}_{4}^{-}$. Sorption in shale is attributed to the organic content (Lynch and Dosch, 1980). The effects of En are shown by increased Tc sorption (by factors of 100-300 in deaerated water. Reduction of ic resulted in a dramatic increase in sorption on the solid phase (Allard et al., 1979). 
(BLANK PAGE)

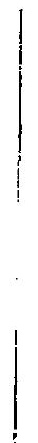

J-6 


\section{K. Eh, pH and Mineralogical Effects on Actinide Sorption}

En: sorption is generally maximized under reducing conditions. There is good evidence to suggest that uranyl sorption is an important "preconcesitrating" step leading to formation of both uranyl and uranous minerals (Langmuir, 1978). Sorption and reduction go hand-in-harid.

Sorption of ip on a fresh rock surface is strongly correlated with the $\mathrm{Fe}^{2+}=$ containing minerals (pyrite and biotite). Oxidation/reduction reactions between $\mathrm{Fe}^{2+} / \mathrm{Fe}^{3+}$ and actinides may be a major mechanism for sorption (Beall, 1980).

pH: Sorption is maximized between a $\mathrm{pH}=6$ to 8.5 for both reduced and oxidized species. Sorption is greatly decreased at pH values below 5 but only slightly decreased at $\mathrm{pH}^{\prime} \mathrm{s}$ above 8 . Changes in $\mathrm{pH}$ may result in desorption.

The desorption of $\mathrm{U}, \mathrm{Am}, \mathrm{Pu}$ on red clay is maximum at $\mathrm{pH}=6$ to 8 but was greatly reduced at $\mathrm{pH}=2.7$ (Erickson, 1980).

Adsorption of $\mathrm{Am}$ and $\mathrm{Np}$ is $\mathrm{pH}$ dependent with maximum adsorption at $\mathrm{pH}=$ 6.5 to 8 ; lower at $\mathrm{pH}=4$ and $\mathrm{s}$ light decrease above $\mathrm{pH}=8$. Sorption of $\mathrm{Np}$ and $\mathrm{Am}$ on biotite and kaolinite decreased from a $4 \mathrm{M} \mathrm{MaCl}$ solution at pH below 5 (Beall et al., 1980).

$\mathrm{Pu}, \mathrm{Am}$, Ilp show "tendencies" to sorb by factors of 20-1000 times "onto halite with clay" from simulant brine solutions at $\mathrm{pH}=6.5$ to 7.8 (Dosch, 1979).

Concentration factor of $U$ in humic acid relative to $U$ in solution at a $\mathrm{pH} \sim 5$ is 10,000 to 1 (Dyck, 1978).

If reduction of the uranyl species does not follow adsorption, uranyl can De desorbed by increasing the pH (Langmuir, 1978).

pH dependence for Am and NP sorption with low sorption at $p H=4$, maximum at $\mathrm{pH}=6.5$ to 8 and then levelling out or slight decreases at higher pH. 
Order of increasing sorption capacity among the common igneous minerals is: quartz < feldspar with augite and olivine < kaolinite and biotite. In the case of biotite and kaolinite a decrease in sorption occurs in a $4 \mathrm{M} \mathrm{NaCl}$ solution of pH below 5 (Beall et al., 1980).

Mineralogy/Sorption: Some data suggest that clays are relatively unimportant as concentrators of uranium during ore deposition but may be important preconcentrators, leading to formation of uranyl and uranous minerals. Experimental data by Langmuir (1978) shows the following heirarchy for enrichment by adsorption:

Amorphous $\mathrm{Ti}(\mathrm{OH})_{4}>$ amorphous $\mathrm{Fe}^{3+}$ oxyhydroxide > peat > finegrained goethite $>$ phosphorites $>$ montmorillonite $>$ kaolinite. Uranium is adsorbed on zeolites within a Miocene sandstone and conglomerate at the Tono Mine, Japan (Katayama et al., 1974). Am and $U^{4+}$ were sorbed on the glass phase and on clay in tuffaceous alluvium and on zeolites in tuff (Erdal et al., 1979).

Attapulgite clay has a significantly higher affinity for actinides than kaolinite and montmorillonite. Nevertheless, kaolinite and montmorillonite have very rapid exchange reactions with actinides and rare earths that take less than 15 minutes to come to equilibrium. Attapulgite clay in contrast takes as long as nine days to reach equilibrium (Beall, 1979). 


\section{Conditions for Hydrotherinal Ore Formation}

1. $\mathrm{pH}$

pH varies as a function of temperature pressure and dissolved solids. Tne $\mathrm{pH}$ of pure water will decrease on simple heating from 7.0 at $25^{\circ} \mathrm{C}$ to 5.8 at $150^{\circ} \mathrm{C}$, due to changes in the dissocation constants with temperature (Hanor, 1979). Note, however that the neutral pH point changes from the normal 7.0 to

\section{7 at $230^{\circ} \mathrm{C}$.}

Relationships between bulk brine composition and $\mathrm{pH}$ can be generalized.

$$
\begin{array}{ll}
\text { High } \mathrm{SO}_{4}-\mathrm{HCO}_{3} \text { waters } & \mathrm{pH} \simeq 8.0 \pm 0.5 \mathrm{pH} \\
\text { High Na-Cl waters } & \mathrm{pH} \simeq 7.1 \pm 0.5 \mathrm{pH} \\
\text { High Na-Ca-Cl waters } & \mathrm{pH} \simeq 6.7 \pm 0.5 \mathrm{pH}
\end{array}
$$

This compositional sequence roughly corresponds to increasing derth or a progressive release of $\mathrm{H}^{+}$with depth (with diagenesis) (Hanor, 1979).

Field evidence suggests that ore-bearing fluids are nearly net ,ral and that strong acids and bases are exceptional. However, deep (hot) pH effects are confusing due to above mentioned changes in $\mathrm{pH}$ and neutral point. The chemical character of fluids near the surface is not a reliable indication of chemical properties at greater depths because of contamination by surface or reactions with wall rocks and changes in temperature and pressure. For example, sulfur present may be oxidized near the surface, tnus forming sulfuric acid and lowering the PH (Park and Mcoiarmid, 1975; Weissberg, 1969).

Salton Sea Brines have an overall $\mathrm{pH}=5.5$ at $25^{\circ} \mathrm{C}$. Red Sea Brines have $\mathrm{pH}=6.5$ (Stanton, 1972). Fumarolic (volcan ic) gases and their associated not water solutions seem to have an extremely low pH.

The concentration of both sulfide and carbonate ions is $\mathrm{pH}$ dependent. Oxidation of any insoluble sulfide leads to the formation of acidic solutions. The degree of acidity depends on the nature of the metal ion, 
particularly the extent of its nydrolysis, or on the insolubility of its hydroxide. Iron sulfides produce the most acidic of all such solutions in the weathering environment because of the precipitation of $\mathrm{Fe}_{2} \mathrm{O}_{3}$.

\section{En}

New Zealand geothermal waters have an Eh $=-0.50$ to $-0.60 \mathrm{~V}$, based on the observed iron sulfide mineralogy and a deep water $\mathrm{pH}=6.1$.

En values are commoniy calculated from $\mathrm{pH}$, temperature and relative concentrations of members of a redox pair, like sulfide/sulfate or $\mathrm{CH}_{4} / \mathrm{CO}_{2}$, because direct measurements of deep waters or of fluid inclusions are extremely difficult. In general ground water abo:e the water table is oxidizing whereas that below the water table has a low Eh. Fumarolic gases and associated heated waters have an Eh sufficiently low for deposition of sulfides.

\section{Pressure}

Most ore deposits form at depths of less than $20 \mathrm{~km}$; this limit is set by the facts that temperatures at $20 \mathrm{~km}$ are of the order of $600^{\circ} \mathrm{C}$ and fractures cannot long remain open because of the plastic behavior of rocks under weight of overlying material. So $2,000 \mathrm{~atm}$ is the upper limit for deposition in veins but most ores are formed at pressures of the order of a few hundred atmospheres.

Most veins and replacenent deposits form over a temperature range from 50 to $550^{\circ} \mathrm{C}$. Ores generaliv do not form at a single temperature but over a temperature interval. Deep artesian and subartesian waters can reach very nigh temperatures $\left(T>300^{\circ} \mathrm{C}\right)$ as a result of normal thermal gradient (temperature increase expected with depth). The Red Sea orines are probably

100 to $150^{\circ} \mathrm{C}$. Salton Sea brines are hotter. Fluid inclusion studies indicate 
a temperature range of 50 to $550^{\circ} \mathrm{C}$ for ore deposits, e.g., limestone lead-zinc deposits $<100^{\circ} \mathrm{C}$ to $200^{\circ} \mathrm{C}$; deposits associated with subsurface igneous activity $150^{\circ}$ to $400^{\circ} \mathrm{C}$; pegmatite ores $>500^{\circ} \mathrm{C}$.

\section{Temperature}

Temperature influences $\mathrm{pH}$. The $\mathrm{pH}$ of pure water will decrease (become acidic) simply from heating, e.g., $\mathrm{pH}=7.0$ at $25^{\circ} \mathrm{C} ; \mathrm{pH}=5.8$ at $150^{\circ} \mathrm{C}$, (Hanor, 1979).

At temperatures of $200-300^{\circ} \mathrm{C}$, the assemblage potassium-feldspar-kaolinite should react to form muscovite-quartz. So, a given mineral assemblage may become unstable under the elevated temperature conditions in a radioactive waste disposal site (Hanor, 1979, p. 158). This is an example of one of scores of possible hydrothermal alteration reactions controlled in part by temperature.

"Evidence to date suggests that high temperatures $\left(>80^{\circ} \mathrm{C}\right)$ and high salinities $(>200 \%)$ or high dissolved sulfide concentrations favor the partitioning of metals into sedimentary fluids. Such conditions permit the formation of stable aqueous-metal complexes $\left(\mathrm{Cl}^{*}\right.$ and $\left.\mathrm{HS}^{-}\right)$and $\mathrm{a}^{-*}$ ar to enhance the diagenetic destruction of the minerals or organic compounds which contain the metals. Active Salton Sea brines have temperatures of $40-60^{\circ} \mathrm{C}$ although the original inflow temperatures are above $100^{\circ} \mathrm{C} . "$ (Weissberg, 1979). Stanton (1972) suggests maximum temperatures of inflow in the range 130 to $220^{\circ} \mathrm{C}$ where the active Red Sea Brines measure $34-56^{\circ} \mathrm{C}$. "Most volcanic area thermal waters are dilute salt solutions at $200-300^{\circ} \mathrm{C}$ with very low concentrations of base metals, silver and gold," (Park and McDiarmid, 1975). High temperatures tend to promote disorder in a mineral structure and under these conditions other elements are readily absorbed and retained, (Park and McDiarmid, 1975). This statement identifies a potential avenue of research in 
adsorption effects at elevated temperatures as a function of rock type and other variables.

\section{Supercritical Solutions}

Above the critical temperature of water, gases behave more like liquids; gases may therefore carry consideradle amounts of metallic elements; high density steam has soivent properties simila to those of liquid water.

Park and McDiarmid (1975) note that in the Valley of Ten Thousand Smokes different mineral assemblages formed around the vents as the temperature dropped; the early phases of mineral deposition being characterized by magnetite; the later phase by galena and sphalerite.

Temperature affects:

1, the solubility (products) of sulitides and oxides;

2. the formation and stability of complex ions; and

3. the hydrolys is constants of ligands, such as $\mathrm{Cl}$. "In most cases, but not a1?, a decline in temperature will cause a reduction in solubility." Therefore, cooling and associated decrease in solubility and complex stability is a likely mechanism for ore deposition and has been so considered in classic ore study. Cooling may be due to:

1. mixing with cold near-surface water,

2. adiabatic decompression and/or

3. heat loss to wall rock (Skinner, 1979).

The average geothermal gradient in older sedimentary basins is $15-40^{\circ} \mathrm{C} / \mathrm{km}$. As fluids are expelled from deep sediments, sediment porosities in tinermaliy insulating zones decrease. Geothermal gradients should then also decrease as the basin cools off (Hanor, 1979). So geothema? gradient of a sedimentary basin is a function of age. Oider basins may be better candidates for waste disposal sites because they are cooler. 


\section{Composition of Solutions}

The composition of ore solutions can be inferred from investigations of fluid inclusions (remnants of depositing solutions contained within ore-associated minerals), wall rock interactions (alteration), and presently active heated waters. In all cases, solution compositions are probably altered by near-surface interactions and so do not necessarily represent exactly the original mobilizing solution. Nevertheless, these solutions may still contain metal ions or associate closely with ore deposits such to provide valuable information on the general geochemical characteristics of original solutions.

Ground water (i.e., supergene enrichment), sea water (i.e., manganese modules), and igneous solutions (i.e., fumaroles) can transport significant quantities of metals. The Salton Sea and Red Sea brines are significant carriers of metal ions. The salinities of both are slightly more than $25 \%$ and contain a great abundance and variety of metal ions. Fumarolic gases contain large amounts of $\mathrm{HCl}, \mathrm{H}_{2} \mathrm{SO}_{4}$ and $\mathrm{HF}$.

Fluid inclusions studies indicate the solutions to be aqueous with $\mathrm{CO}_{2}$, hydrocarbons and sulfur gases present in varying amounts. The solutions are almost always highly saline ( 0 to $40 \%$ by weight) and contain as major components $\mathrm{Na}^{+}, \mathrm{K}^{+}, \mathrm{Ca}^{4+}, \mathrm{Mg}^{++}, \mathrm{Cl}^{-}$, and $\mathrm{Sn}_{4}{ }^{2}$ plus minor components $\mathrm{Li}^{+}, \mathrm{Al}^{+3}$, $\mathrm{BO}_{3}^{-3}, \mathrm{PO}_{4}^{-3}, \mathrm{SiO}_{3}^{-2}, \mathrm{HCO}_{3}^{-}$and $\mathrm{CO}_{3}^{-2}$. Elements commonly added to the wall rock adjacent to ore deposits include: $\mathrm{Si}, \mathrm{C}, \mathrm{Mg}, \mathrm{Na}, \mathrm{K}, \mathrm{Ca}$ and $\mathrm{Fe}$. Fumarolic waters comonly contain insufficient sulfur for the precipitation of all arajlable sulfophile metals as sulfides. 
7. Complexing in Ore Solutions

Chloride and bisulfide complexes are the two most plausible agents for increasing the solubility of metals. Helgeson (1965) has studied chloride complexes, and Barnes and Czamanske (1967) discuss sulfide complexes. Chloride complexes are probaoly significant mobitizers when there is (1) abundant chloride ion, (2) the $\mathrm{pH}$ is a little on the acidic side of neutral, and (3) temperatures are moderately elevated. Bisulfide complexes appear to form when there is abundant (1) sulfide $\left(\mathrm{HS}^{-}\right),(2)$ the solution is alkaline, and (3) nas a low Eh. Stable bisulfide complexes, especially for copper ano zinc, lead to substantial increases in sulfide solubility. Most of the summarizing material above is drawn from Krauskopf (1967) and Stanton (1972).

\section{Geotnermal Systems}

NOTE: Suggested focus for further work - A comparison of the geochemical characteristics of metal-bearing vs. nonmetal-bearing geothermal and brine systems may elucidate the conditions favorable for mobility of ore-bearing solutions, especially for systems in the near-surface environment. Much data should be available on geothermal springs and prospects as a result of the recent DOE efforts to investigate potential sites for geothermal power.

Metal deposits have been observed forming from metal-bearing brines in the Red Sea, Salton Sea, New Zealand, Caspian Sea and other places. A detailed literature suminary of the known characteristics of these systems and a comparison with non-metal bearing geothermal springs might reveal general conditions which favol metal mobility in crustal materials.

Metal concentrations in the New Zealand geothermal waters are very low. Their great enrichment in precipitates indicates that high metal concentrations in water are not required to form ore-grade materials. Critical factors are deposition rate and time (Weissberg et al., 1979). 
In the Valley of Ten Thousand Smokes different assemblages formed around the vents as the temperature dropped, the early phase being characterized by magnetite, the later phase by galend and sphalerite. Incrustations

contained: $\mathrm{Fe}, \mathrm{Pb}, \mathrm{Zn}, \mathrm{Mo}, \mathrm{Cu}, \mathrm{As}, \mathrm{Sb}, \mathrm{Sn}, \mathrm{Ag}, \mathrm{Ni}, \mathrm{Co}, \mathrm{Bi}, \mathrm{S}, \mathrm{O}, \mathrm{F}, \mathrm{Cl}$, Se, Te (Park and McDiaritid, 1975).

Several tons per year of base and precious metals in sludges are removed for disposal from the Salton Sea geothermal test plant site (personal communications, Union 0 il Co.). 
(BLANK PAGE)

$L-8$ 


\section{i. Complexes}

\section{General}

Formation of complex ions, charged particles consisting of several atoms, increases solubility of some metals by many orders of magnitude (Park and McDiarmid, 1975). "Complex ions, formed between metals and ligands in solution, serve as shieids, or carriers for the metals consequently inhibiting precipitation of sulfide minerals" (Skinner, 1979).

"The relative abundance of anions in shale interstitial waters is: $\mathrm{HCO}_{3}>\mathrm{SO}_{4}>\mathrm{Cl}$ or $\mathrm{SO}_{4}>\mathrm{HCO}_{3}>\mathrm{Cl}$, in contrast to waters in sands, which are dominated by chloride" (Hanor, 1979).

"The ore-carrying capacity of hydrothermal solutions is determined more by the activity of these ligands than by abundance of the metals in host rock which varies over a comparatively narrow range" (Barnes, 1979). Note: Barnes is suggesting that the most significant factor in the mobility of ore solutions is the stability and characteristics of certain complexes, mainly sulfur and chloride complexes.

In terms of ore element mobility, chloride complexes are very significant above $200-250^{\circ} \mathrm{F}$ for mobilizing netals. Above $300^{\circ} \mathrm{F}$ organic complexes are dissociated and so are not significant. Organic complexes can be very important at low temperature however (Gardner, 1974). Sulfide complexes are relatively more important below $250^{\circ} \mathrm{F}$ than above.

Chloride Complexes. The relative stability of $\mathrm{Cl}^{-}$coinplexes is: $\mathrm{Cu}>\mathrm{Zn}>\mathrm{Pb}>\mathrm{Ag}>\mathrm{Hg}$.

1. $P b$ is mobile up to $600 \mathrm{ppm}$ in solution o $100-374^{\circ} \mathrm{F}$.

2. The formation of lead chloride complexes $\left(\mathrm{PbCl}^{+}\right.$and $\left.\mathrm{PbCl}_{4}\right)$ in the solution is responsible for this solubility (Helgeson, 1964). 
Red Sea and Salton Sea brines are very high in chloride. White (1968) notes that metals are presumed to be soluble due to chloride complexing, since not enough sulfur is present to account for the mobility of the metals.

Skinner (1979) says "from present evidence the role of chloride complexes seems more important than other complexes."

Water in regions of recent volcanic activity is commonly characterized by an abundance of $\mathrm{NaCl}$ grading into acidic sulfate-chloride waters (Park and MCDiarmid, 1967).

$\mathrm{NaCl}$ and $\mathrm{KCl}$ are abundant in many deep artesian brines. Chloride complexes have an even greater stability (capacity for remaining in solution as ions) than $\mathrm{NaCl}, \mathrm{HCl}$ or $\mathrm{KCl}$ in the temperature-pressure range of $100-374^{\circ} \mathrm{F}$ and 1-2000 atm. These complexes are virtually dissociated $025^{\circ} \mathrm{F}$ (Stanton, 1972).

Sulfur Complexes. Sulfur complexes are thought to be one of two kinds (the other being chloride) of complex ions that seem to be most important in hydrothermal solutions. In order for the sulfide complexes to form, the concentration of reduced $S$ in solution must greatly exceed that of the metal species (Skinner, 1979). But Salton Sea brines have metals much more abundant than sulfur.

Sulfur is a significant complexer in alkaline pH's. Exarnples are:

Zinc - $2700 \mathrm{mg} / 1 \mathrm{Zn}$ dissolves in a aqueous solution e $25^{\circ} \mathrm{F}, \mathrm{P}_{\mathrm{H}_{2} \mathrm{~S}}=$ $7 \mathrm{~atm}$ and $\mathrm{pH}=8.2$. If the solution becomes even weakly acidic, the complexing and hence solubility, decreases markedly.

Copper. - up to $1300 \mathrm{mg} / 1$ of $\mathrm{Cu}$ dissolves in aqueous solutions $204^{\circ} \mathrm{F}$, 24 atm pressure and $4.1 \mathrm{~N} \mathrm{NaHS} \mathrm{(mechanism} \mathrm{thought} \mathrm{to} \mathrm{be}$ bisulfide complexes) (Stanton, 1972). 


\section{Metal Complexes}

Copper Complexing. Near-surface waters carry copper as several complexes including $\mathrm{Cu}(\mathrm{OH})_{2} ; \mathrm{Cu}\left(\mathrm{CO}_{3}\right)_{2}^{2-} ; \mathrm{CuSO}_{4}$ and $\mathrm{CuCl}^{+}$. The recent discovery of copper porphyrins in deep-sea sediments suggests that organic complexes should De added to the list. Transport by chloride complexes can account for the " low-temperature" formation of red bed (sedimentary) deposits. In anionic (reducing) marine waters, the bisulfide complexes have been calculated to be the dominant inorganic aqueous Cu species present.

Chloride complexing with copper is most significant for weakly acidic solutions $250-350^{\circ} \mathrm{F}$ and total sulfur from 0.1 to $1.0 \mathrm{M}$. Bisulfide complexes become relatively more important below $250^{\circ} \mathrm{F}$. Solubilities of Cu may easily reach into the $1000^{\prime} s$ of $\mathrm{ppm} \mathrm{Cu}$ in solution above $250^{\circ} \mathrm{F}$ - presumably due to chloride complexes.

Zinc: The dominant complex of $2 n$ in hydrothermal solutions is $\mathrm{ZnCl}_{2}$.

Lead: Various complexes with $\mathrm{HS}^{-}$dominate over temperature which range from $25^{\circ} \mathrm{F}$ :0 $300^{\circ} \mathrm{F}$ in neutral to acidic solutions. At total $\mathrm{s}<1.0 \mathrm{M}, \mathrm{Pb}(\mathrm{HS})_{3}^{-}$ Lar exist at temperatures below $50^{\circ} \mathrm{F}$ and in neutral to slightly alkaline solutions.

Mercury: lppm Hg dissolves as bisu!fide complexes in equilibrium with metacinnabar at $25^{\circ} \mathrm{F}$ in near-neutral solutions of total $S=0.1 \mathrm{M}$. The soludility increases approximately two times by $100^{\circ} \mathrm{F}$ and 4 to 7 times Dy $200^{\circ} \mathrm{F}$.

Iron: Increasing association of $\mathrm{Fe}$ with $\mathrm{Cl}^{-}$is characteristic of $\mathrm{Fe}^{+2}$ at higher temperatures. Solubility increases steeply above $250^{\circ} \mathrm{F}$ so that tens to 
thousands of ppm of $\mathrm{Fe}$ are stable in $\mathrm{Cl}^{-}$complexes at $350^{\circ} \mathrm{F}$ in the $\mathrm{pH}$ range in which muscovite is stable. At lower temperatures, ferrous chloride complexes become ineffective for moving iron in the quantities observed. Bisulfide complexes provide an alternative. Experimental studies show that bisulfide complexes are sufficiently stable at temperatures up to at least $300^{\circ} \mathrm{F}$. Organic and/or ammine complexes may be significant at low temperatures. 


\section{DISCLAIMER}

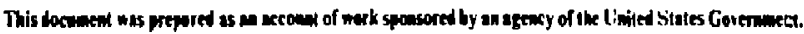

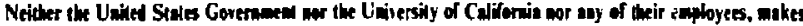

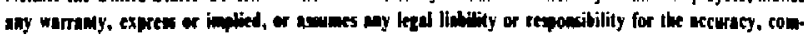

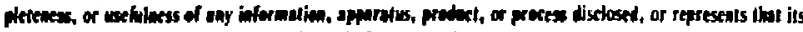

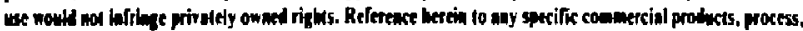

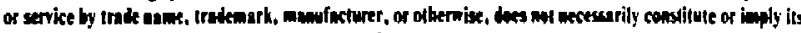

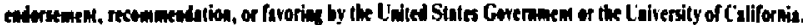

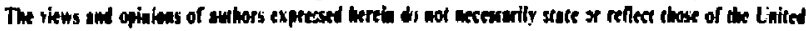

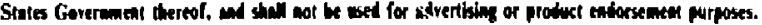

